\title{
An Assessment of Post-Taliban Media Development in Afghanistan (2002-2017)
}

\author{
by \\ Janan Mosazai \\ A thesis submitted to the Faculty of Graduate and Postdoctoral Affairs in partial \\ fulfillment of the requirements for the degree of
}

Master of Journalism (MJ)

in

The School of Journalism and Communication

Carleton University

Ottawa, Ontario

(C) Janan Mosazai 


\begin{abstract}
This research project constitutes the first of its kind in-depth baseline assessment of the growth and development of the Afghan media sector post-2001. The assessment utilizes the United Nations Media Development Indicators (MDIs) for this specific purpose.
\end{abstract}

In doing so, this thesis project tests the assumption that despite pressures from both the government, the Taliban-led insurgency and other non-government actors in Afghanistan, and challenges related to financial sustainability and professionalism, the post-Taliban Afghan independent media sector is sufficiently robust, resilient and diffuse across Afghanistan and enjoys widespread political and public support that it will continue to survive and grow as a strong social and political force in the country, and thus contribute to the further entrenchment of democracy in Afghanistan, unlike all other past short-lived instances of media freedom in Afghanistan's history of struggle for constitutionalism and democracy going back to the $19^{\text {th }}$ century. 


\section{Acknowledgements}

I owe a profound debt of gratitude to my thesis supervisor, Prof. Christopher Dornan, for his guidance, support and great patience throughout my association with the School of Journalism — in his strong support to my initial application to the MJ program, in his teaching and throughout this research project. Prof. Dornan is a rare educator who is not only an outstanding academic but also a wise, caring teacher. I am grateful to him. I am also thankful to the many professors and academic support staff at the School of Journalism from whom I learned a great deal. I would not have been able to complete this project without the constant encouragement and support of my wife Dr. Zangah Mosazai. My deep appreciation also goes to the many reporters, editors and media activists who agreed to the research interviews to share their reflections on the development of Afghan media in the last decade and a half and who, in the face of great odds and risk of personal harm, continue to keep the flame of press freedom and freedom of expression alight. This thesis is dedicated to them. 


\section{Table of Contents}

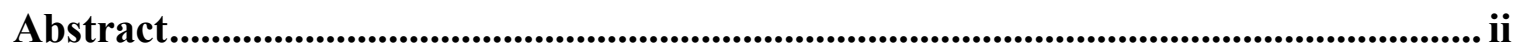

Acknowledgements ........................................................................................................ iii

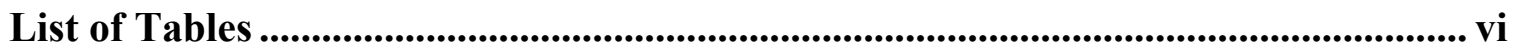

List of Acronyms .................................................................................................. vii

1 Chapter: INTRODUCTION, THEORITICAL FRAMEWORK, AND

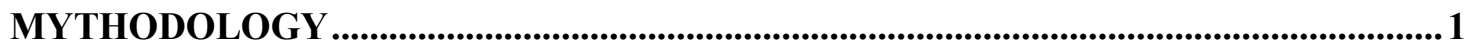

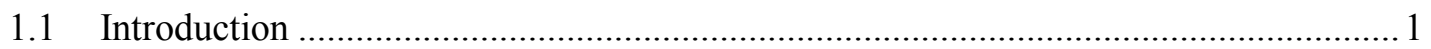

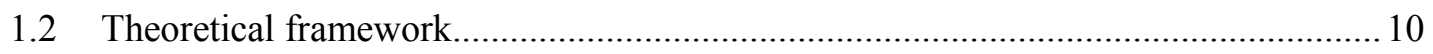

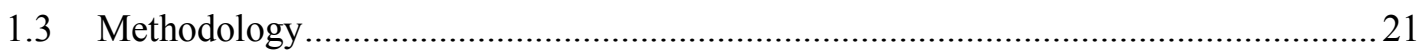

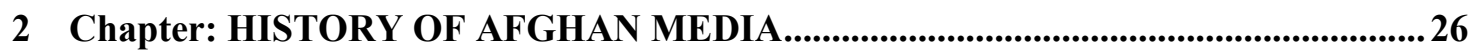

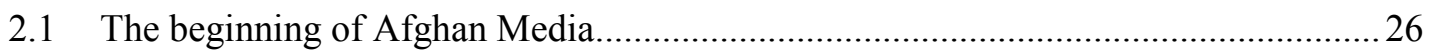

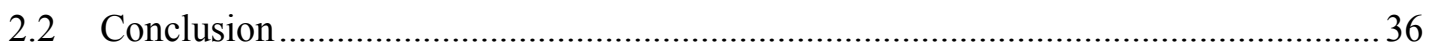

3 Chapter: LEGAL AND POLICY FRAMEWORK....................................................39

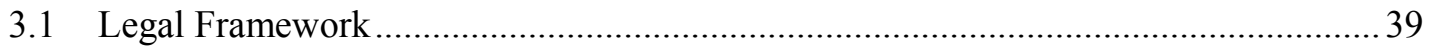

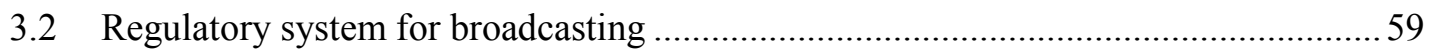

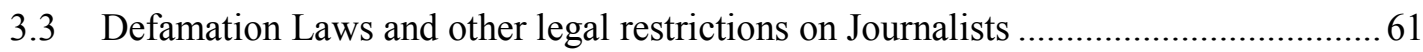

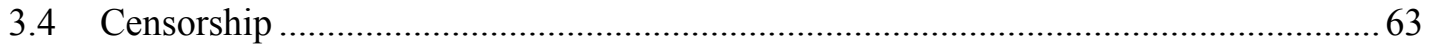

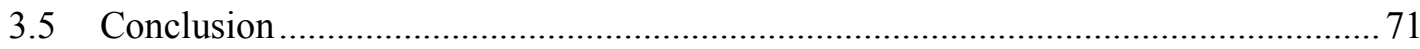

4 Chapter: PLURALITY AND DIVERSITY OF MEDIA ............................................... 73

4.1 State takes positive measures to promote pluralist media .......................................... 74

4.2 State ensures compliance with measures to promote pluralist media......................... 76

4.3 A diverse mix of public, private and community media........................................... 79

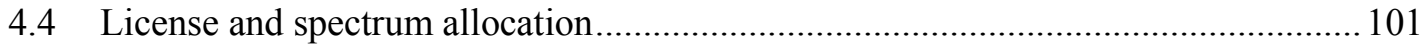

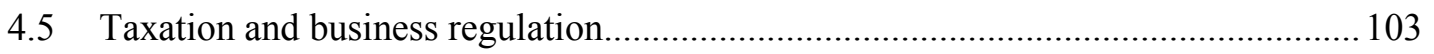




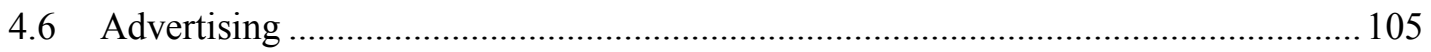

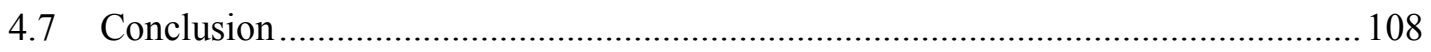

5 Chapter: MEDIA AS A PLATFORM FOR DEMOCRACY ...................................... 111

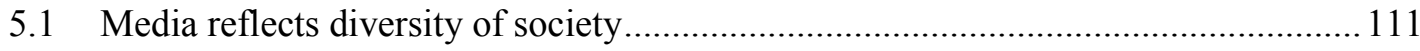

5.2 Media, women's participation and hiring practices.............................................. 117

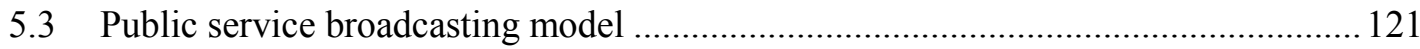

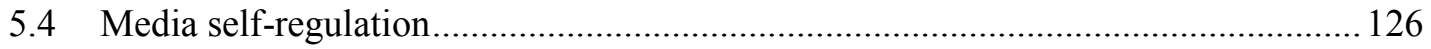

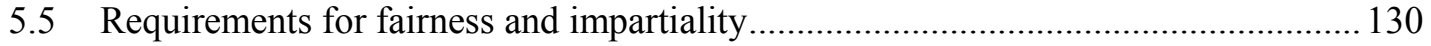

5.6 Levels of public trust and confidence in the media ................................................. 133

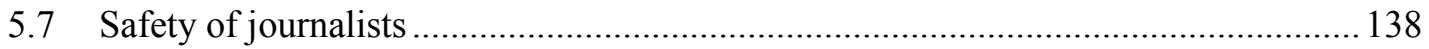

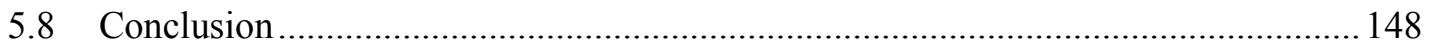

6 Chapter: PROFESSIONAL CAPACITY BUILDING AND SUPPORTING

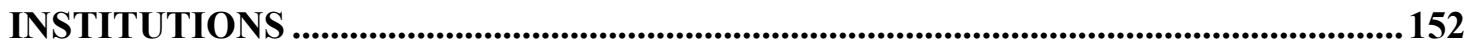

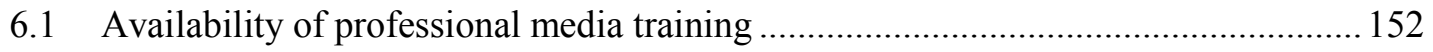

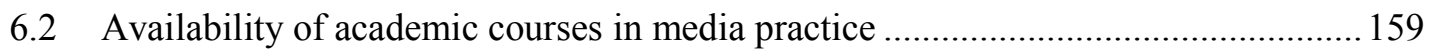

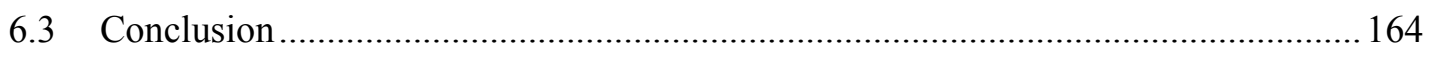

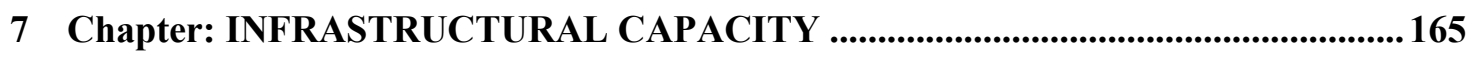

7.1 Availability of technical resources for the media ................................................. 165

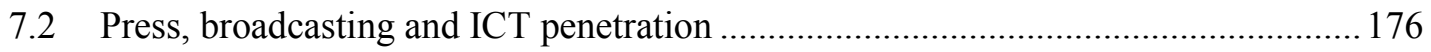

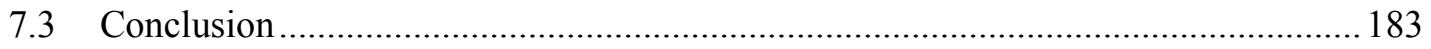

8 Chapter: FINAL CONCLUSIONS AND RECOMMENDATIONS............................ 185

Bibliography or References..................................................................................... 195 


\section{List of Tables}

Table 1: $\quad$ Leading $10 \mathrm{TV}$ channels in Afghanistan by percentage of audience share (average of rates in the August 2013 - November 2014 period)

Table 2: $\quad$ Leading 11 radio channels in Afghanistan by percentage of average daily reach (average of rates in the August 2013-November 2014 period)

Table 3: $\quad$ Print media audience shares

Table 4: $\quad$ Percentage of media penetration rates in June 2010

Table 5: $\quad$ Percentage of audience preferences for TV and radio as sources of information in a four-year period (2013-2016)

Table 6: $\quad$ Afghan peoples' levels of confidence in the country's media (2007-2017)

Table 7: $\quad$ Total number of students enrolled in journalism programs in Afghanistan in 2017

Table 8: $\quad$ Growth of mobile phone subscriptions in Afghanistan (2002-2016)

Table 9: $\quad$ Growth of internet use in Afghanistan by percentage of population (20022016) 


\section{List of Acronyms}

\begin{tabular}{ll} 
AJSC & Afghanistan Journalists Safety Committee \\
ACKU & Afghanistan Centre at Kabul University \\
AJC & Afghanistan Journalists Centre \\
AJMEF & Afghanistan Journalists and Media Entities Federation \\
ANDS & Afghanistan National Development Strategy \\
ANJU & Afghanistan National Journalists Union \\
ARTF & Afghanistan Reconstruction Trust Fund \\
ATRA & Afghanistan Telecommunications Regulatory Authority \\
AWJU & Afghan Women Journalists Union \\
BNA & Bakhtar News Agency \\
SCHRN & Civil Society and Human Rights Network \\
CIMA & Centre for International Media Assistance \\
CLJ & Constitutional Loya Jirga \\
CPJ & Committee to Protect Journalists \\
CSO & Civil Society Organization \\
GMIC & Government Media and Information Centre \\
Gbps & Gigabits per second \\
ICT & Information and Communication Technology \\
IFES & International Foundation for Electoral Systems \\
IMS & International Media Support \\
IWPR & Internet Service Provider \\
\hline Instute for War and Peace Reporting
\end{tabular}


LOTFA Law and Order Trust Fund for Afghanistan

MDIs Media Development Indicators

MCIT Ministry of Communications and Information Technology

MOIC Ministry of Information and Culture

MSS Media Support Systems

NAIC National Access to Information Commission

NDS National Directorate of Security (Afghanistan's premier intelligence

agency)

NED National Endowment for Democracy

NGO Non-Government Organization

NSC National Security Council

SAFMA South Asia Association for

TEFA Transparent Elections Foundation of Afghanistan

UN United Nations

UNESCO United Nations Educational, Scientific and Cultural Organization

UNDP United Nations Development Program

UNSC United Nations Security Council

USAID United States Agency for International Development

USIP United States Institute of Peace 


\section{Chapter: INTRODUCTION, THEORITICAL FRAMEWORK,}

\section{AND MYTHODOLOGY}

\subsection{Introduction}

Afghanistan today boasts a diverse and rich media landscape. There were more than 400 print publications, around 150 radio stations, and more than 75 television stations operating in 2012, most of them privately owned. Radio remains the main source of news and information, particularly in areas outside major cities, and television has been catching up rapidly with radio. Due to low literacy rates (the national average is about 30 percent), newspaper readership remains low. ${ }^{1}$

Compared to the Taliban regime under which there was only one radio station, a limited number of government-owned newspapers, and TV was banned, ${ }^{2}$ this level of growth and development in the media sector in the span of a decade and a half is nothing short of an unprecedented transformation. The United States Institute of Peace called this rapid change as an evolution "at warp speed since the fall of the Taliban in 2001."3 The total number of journalists working in the media sector in Afghanistan is estimated to be 12,553 , of whom 2,133 or 17 percent are women. ${ }^{4}$ Given the overall conservative nature of Afghanistan's overwhelmingly Muslim population and the prevailing difficult security

\footnotetext{
${ }^{1}$ Freedom of the Press Report on Afghanistan 2013, Freedom House, p. 60, https://freedomhouse.org/sites/default/files/FOTP\%202013\%20Full\%20Report.pdf, (Accessed 25 April 2017)

${ }^{2}$ Afghanistan in 2014: A survey of the Afghan people, Asia Foundation, p. 117, http://asiafoundation.org/resources/pdfs/Afghanistanin2014final.pdf, (Accessed 25 April 2017)

3 Ann Procter, Afghanistan's Fourth Estate: Independent Media, 10 August 2015, https://www.usip.org/publications/2015/08/afghanistans-fourth-estate-independent-media, (Accessed 28 April 2017)

${ }^{4}$ Twelve percent increase by women in Afghan media outlets, NAI Supporting Open Media in Afghanistan, 20 March 2017, http://nai.org.af/dr/افزايش_rادرصدى-بانوان-در-رسانه_هاى_افغة/, (Accessed 25 April 2017)
} 
and law and order situation in the country, the relatively high level of women's participation in the media sector is both symbolically and materially significant. It is a stark contrast to the Mujahideen period and the reign of the Taliban when women were not only barred from working in the media sector but also often not allowed or simply too scared to leave their homes without a male escort.

Afghan leaders, Afghanistan's international supporters and the country's media practitioners, therefore, have over the past 15 years touted the unprecedented development of the country's independent media since the fall of the Taliban regime as a major achievement. For example, ToloNews, a 24-hour news channel owned by Moby Group, the country's largest media group, noted that "The last decade in Afghanistan is known as the decade of freedom of speech. Analysts believe that despite government failure in succeeding to institutionalize good governance in the country, it did, however, advance and maintain press freedom for the media."

The Afghan Journalists Safety Committee (AJSC) reported that in 2016 Afghanistan ranked higher than all of its neighbouring countries in freedom of expression and press freedom categories. ${ }^{6}$

\footnotetext{
${ }^{5}$ Afghanistan's press has been free in the past thirteen years, Tolo News, 2 May 2014, http://www.tolonews.com/fa/afghanistan/رسانه_هاى_افغانستان-در _سيزده-سال_اخير-آزا اد-بودهـاند, (Accessed 25 April 2017)

${ }^{6}$ Six months report: January-June 2016, Afghan Journalists Safety Committee (AJSC), 1 July 2016, http://ajsc.af/wp-content/uploads/2016/07/JAN-JUN2016SixMonthsReportENGLISH.pdf, page 3, (Accessed 25 April 2017)
} 
Afghanistan's leaders have taken conspicuous pride in the growth and development of the media sector, and have tried to claim credit for it. Hamid Karzai was interim leader and later elected president between 2001 and 2014. Toward the end of his tenure, he said "in the past 11 years, ensuring press freedom has been one of the greatest achievements of the people of Afghanistan and the Afghan government has unfailingly defended this freedom."

Karzai has described the development of "press freedom and freedom of expression" as one of his three top achievements as the country's leader for 12 years. ${ }^{8}$ On another occasion after he relinquished power, he said the growth and entrenchment of the country's media sector "is now irreversible."

Karzai's successor and the current Afghan president, Mohammad Ashraf Ghani, has similarly voiced his support for press freedom. In a speech to the New York-based Atlantic Council during the height of the 2014 run-off presidential election campaign which he was contesting against Dr. Abdullah Abdullah, Ghani pointed to the development of Afghan media as a key factor enabling the consolidation of Afghanistan's young democracy. He said he was "struck - dumbstruck by the extent to which the presidential debates were watched across the country and weighed, and on that basis

\footnotetext{
${ }^{7}$ Hamid Karzai: Managers of media as the eyes and guides of society carry major responsibilities towards the people and the country, Official Arg Presidential Palace statement, 21 February 2013, http://president.gov.af/fa/news/17655 (Accessed 20 April 2017)

${ }^{8}$ Black and White: Ex-president Karzai on his presidential journey, Tolo TV, https://www.youtube.com/watch?v=92pYA-EkUhE, 3 September 2015 (Accessed 20 August 2015)

${ }^{9}$ Karzai: The principle of freedom of expression in Afghanistan is irreversible, Tolo News, 28 January 2014, http://www.tolonews.com/fa/afghanistan/كرزى-اصل-آز ادى-بيان-در -افغانستان-بركثتـنإيذير -است, (Accessed 28 April 2017)
} 
decisions were made. A free media of course also has rough edges, but by and large the nature of public discourse in Afghanistan has been remarkable."10

As president, Ghani has continued his public support for the media. During a meeting in May 2015 to review his Ministry of Information and Culture's first so-called 100-Day Plan, Ghani said freedom of expression is “an important value of society.” He emphasized the government's "support to freedom of expression and the right of access to information." He also said, "working with the media and (creating) a mechanism for solving their problems must be at the top of the government's agenda."11

In a highly symbolic move, in January 2017 Ghani appointed a prominent Afghan human rights activist as his ambassador-at-large for freedom of expression. At the time, the government said "the president of Afghanistan and the First Lady are supporters of freedom of expression and the press in Afghanistan." It also announced special prizes to be given annually to "those individuals who demonstrate excellence in support of freedom of expression." 12

At the same time, following a nearly week-long barrage of persistent and often harsh criticism from Afghan journalists, media support organizations and other civil society

\footnotetext{
${ }^{10}$ A conversation with Afghanistan Presidential Candidate Dr. Ashraf Ghani, Atlantic Council, 20 May 2014, http:/www.atlanticcouncil.org/news/transcripts/dr-ashraf-ghani (Accessed 15 April 2017).

${ }^{11}$ Official Arg Presidential Palace statement, "President Ghani calls freedom of express an important value of society," 16 May 2015, http://president.gov.af/fa/news/46280 (Accessed 15 April 2017). (Author translation from Dari.)

${ }^{12}$ Decree of President Ghani regarding institutionalization of culture of support for freedom of expression and (freedom of) the press, Afghan Presidential Palace, 22 January 2017, http://president.gov.af/fa/2017/01/22/فرمان-رئيس-جمهور غنى-در -مورد-نهادينه-سا/, (Accessed 25 April 2017)
} 
groups at Ghani's rare gesture to ignore a question from an Afghan journalist during a press conference in Kabul in March 2017, the presidential palace was forced to once again reiterate its commitment to freedom of the press. In a lengthy statement, the government said it, "in accordance with the Constitution, considers freedom of expression as safe from any type of violation and (also) considers the improvement of activities in this sector as one of its fundamental responsibilities." 13

Ghani has also repeatedly stated that the rights and freedoms of the Afghan people, which by law include the right to freedom of expression and press freedom, will not be sacrificed in any peace process with the Taliban armed opposition group. In his address to the joint setting of the United States Congress in March 2015, he said "we will negotiate with the Taliban from a position of strength, not weakness, so that the hardfought gains in education, health, governance, media freedom and women's rights are not lost." 14

It is apparent from the above that both the present government and the one it succeeded have paid the necessary lip service to the protection of press freedom and development of the media sector. Government leaders and others have been readily prepared to claim credit for the growth of this sector in Afghanistan both domestically and on the international stage.

\footnotetext{
${ }^{13}$ Brief report on the activities of the national unity government in strengthening freedom of expression, Government Media and Information Centre (GMIC), http://www.gmic.gov.af/dari/features/2964-2017-0411-04-14-59, 9 April 2017, (Accessed 27 April 2017)

${ }^{14}$ President Ghani's address to the U.S. Congress, Arg Presidential Palace official website, 25 March 2015, http://president.gov.af/en/news/president-ghanis-address-to-the-us-congress, (Accessed 15 April 2017)
} 
However, these claims and public statements of support to press freedom, and its role in the development of a democratic state, must be examined against the prevailing realities on the ground in Afghanistan based on available evidence.

Freedom House, in its Freedom in the World 2015 report, classified Afghanistan as "not free.” It noted, "Afghan media continue to expand and diversify, but media workers face major challenges, including physical attacks and intimidation. Despite a 2007 media law intended to clarify press freedoms and limit government interference, a growing number of journalists have been arrested, threatened, or harassed by politicians, security services, and others in positions of power." The media watchdog group added that, "Rapidly expanding use of the internet and mobile telephones has broadened the flow of information, particularly for urban residents, but Taliban attacks on mobile phone infrastructure hinders communications. The elections season was replete with robust coverage via radio, television, newspapers, and the web, and the first-ever televised presidential debate was held in February (2014)." ${ }^{15}$

There are also growing concerns nowadays about the long-term survival of press freedom and independent media outlets in Afghanistan. One of the main reasons for this is a steep decline in financial support from troop-contributing nations that accompanied the exit of most foreign forces from the country in 2014. For example, Human Rights Watch, in a January 2015 report, while noting "the phenomenal growth" of Afghan media since 2001,

\footnotetext{
${ }^{15}$ Freedom in the World 2015: Afghanistan, Freedom House, https://freedomhouse.org/report/freedomworld/2015/afghanistan (Accessed 15 April 2017)
} 
said that "with most foreign military forces having withdrawn from Afghanistan, and a substantial decline in foreign donor assistance to the country, the freedom that spurred the media's growth is in peril."16

Many Afghan journalists are also concerned. In its six-monthly report covering the period of January to June 2016, the Afghan Journalists Safety Committee (AJSC) came to the worrying conclusion that 2016 was "the bloodiest year for journalists in the history of Afghanistan."

The Committee recorded a 38 percent increase in incidents involving journalists, including murder, physical assault, detention and intimidation. It reported that ten journalists were murdered in different parts of Afghanistan in the first six months of that year. It noted that attacks by the Taliban against journalists had "dramatically increased compared to the previous years." However, a particularly worrying finding of the Committee's report was that "individuals linked to the government still account for the majority of cases of violence and intimidation." It added that "amid an increasingly grave backdrop for journalist safety, the government has failed to provide adequate protection to journalists. ${ }^{, 17}$ For its work in support of press freedom in Afghanistan, the AJSC won

\footnotetext{
${ }^{16}$ Stop reporting or we'll kill you: Threats to media freedom in Afghanistan, p. 1, https://www.hrw.org/report/2015/01/21/stop-reporting-or-well-kill-your-family/threats-media-freedomafghanistan (Accessed 24 August 2015), Human Rights Watch, 21 January 2015

${ }^{17}$ Six months report: January-June 2016, Afghan Journalists Safety Committee (AJSC), 1 July 2016, http://ajsc.af/wp-content/uploads/2016/07/JAN-JUN2016SixMonthsReportENGLISH.pdf, page 5, (Accessed 25 April 2017)
} 
the 2017 Free Media Pioneer Award from the Vienna-based International Press

Institute. $^{18}$

Similarly, NAI Supporting Open Media in Afghanistan, a prominent national Afghan media support and advocacy group, has also voiced growing concerns about challenges to freedom of expression and press freedom in the country. In its monthly Media Watch Report from February 2017, for instance, the group noted that despite the notion that the post-Taliban order "was built on the foundation of democracy and freedom of speech, still there are too many hurdles against these values and these problems get from bad to worse every day." It also noted, "there are a remarkable number of journalists who complain from the illegal behaviours of the government authorities."19

The group also noted that lack of financial resources, the overall security situation in the country and difficulties in accessing information from government institutions constitute key challenges that local Afghan media outlets in the provinces away from the capital Kabul faced. ${ }^{20}$

According to the New York-based Committee to Protect Journalists (CPJ), Afghanistan is one of the few countries - others include Pakistan, Iraq, Bangladesh, Syria, Nigeria,

\footnotetext{
${ }^{18}$ Javier Luque, Pioneer Award aids fight for Afghan journalits' safety, International Press Institute, 21 June 2017, https://ipi.media/pioneer-award-strengthens-fight-for-journalist-safety-in-afghanistan/ , (accessed 25 June 2017)

${ }^{19}$ Media Watch Report: Monthly report number 141, Nai Supporting open media in Afghanistan, February 2017, page 3, http://nai.org.af/files/documents/mw/Nai\%20Monthly\%20Report\%20English\%20141.pdf, (Accessed 25 April 2017)

${ }^{20}$ Media Watch Report: Monthly report number 141, Nai Supporting open media in Afghanistan, February 2017, page 7, http://nai.org.af/files/documents/mw/Nai\%20Monthly\%20Report\%20English\%20141.pdf, (Accessed 25 April 2017)
} 
Philippines - where attacks against journalists, including murders, beatings, torture and intimidation, go largely unpunished. ${ }^{21}$

In short, given the government's repeated reassurances regarding its commitment and support to the development of independent media on the one hand, and increasing concerns both among Afghan journalists as well as international observers about the future of press freedom in Afghanistan, it is important to study the reality on the ground based on a set of concrete criteria. To that end, this thesis project will carry out a first of its kind in-depth study of the development of Afghan media in post-Taliban Afghanistan using a specific set of media development indicators developed, adopted and used by the United Nations (see below).

In doing so, this thesis project will also test the assumption that despite pressures from both the government, the Taliban-led insurgency and other non-government actors in Afghanistan (local strongmen, drug lords, etc), and challenges related to financial sustainability and professionalism, the post-Taliban Afghan independent media sector is sufficiently robust, resilient and diffuse across Afghanistan and enjoys widespread political and public support that it will continue to survive and grow as a strong social and political force in the country, and thus contribute to the further entrenchment of democracy in Afghanistan, unlike all other past short-lived instances of media freedom in Afghanistan's history of struggle for constitutionalism and democracy.

\footnotetext{
${ }^{21}$ Witchel, Elisabeth, Getting away with murder, Committee to Protect Journalists (CPJ), 27 October 2016, https://cpj.org/reports/2016/10/impunity-index-getting-away-with-murder-killed-justice.php, (Accessed 26 April 2017)
} 
In addition to the brief introduction above, the thesis will be developed in three broad parts, namely the theoritical framework within which the thesis project will be situated, the specific methodology to be used, and the findings and conclusions of the research.

\subsection{Theoretical framework}

It is well-argued that development and democratization are most successful if they reflect the will, desire and needs of a country's citizens. ${ }^{22}$ Development and democratization in this sense must by definition go beyond the mere electoral test of democracy (though free and fair elections are and must remain a necessary, essential element of testing any state's claim to democracy) and include other key criteria such as the citizens' ability to assemble and express themselves freely, including through an independent media, and the ability of various constituencies to influence policy decisions by their elected government through such a free, open public discourse. This is where the existence of a free, independent media is vital to the exchange of information and giving voice to citizens in a democratic context.

James Curran, for example, holds that a free media is a fundamental requirement for democracy in any society and that political accountability in a democracy requires, among other elements, "a media system that delivers a sufficient supply of meaningful public affairs information to catch the eye of relatively inattentive citizens." 23

\footnotetext{
22 Copeland, David A., The Idea of a Free Press, Northwestern University Press (2006)

${ }^{23}$ Curran, James, Media and Democracy, Routledge, (2011), page 47
} 
Curran also argues that media in a democratic setting should, as a minimum requirement, also provide a platform for the main diverse interests in society to be able to express themselves freely and openly. He adds that such a democratic media should facilitate the participation of these diverse interests in society "in the public domain, enable them to contribute to public debate and have an input in the framing of public policy. The media should also facilitate the functioning of representative organizations, and expose their internal processes to public scrutiny and the play of public opinion. In short, a central role of the media should be defined as assisting the equitable negotiation or arbitration of competing interests through democratic processes." 24

A rather obvious extrapolation of this requirement in terms of the role of effective media in society would be to throw light on the workings, achievements and failures of state institutions, including the government, parliament, judicial system and other public bodies entrusted with the provision of public goods such as security, basic services and law and order.

Curran also holds that media have certain responsibilities, which include their ability to provide "a succinct, impartial news briefing, and be ready to sound an alarm if there is a crisis or acute problem that warrants the 'monitorial' citizen's urgent attention. In addition, there need to be quality media, inspired by a sense of professional mission,

\footnotetext{
${ }^{24}$ Curran, James, essay titled "Rethinking the media as a public sphere" in Communication and Citizenship: Journalism and the Public Sphere, edited by Peter Dahlgren and Colin Sparks (1991), Routledge, New York (1991)
} 
providing intelligent, extensive news coverage and facilitating informed dialogue between elites. ${ }^{, 25}$

Curran also posits that in a democratic context, "the central role of the media is to assist the public to reach informed and considered judgements not merely at election time but between elections, and to enable the public to exert a cumulative influence on the direction of society."26

Michael Schudson similarly makes the case that "the job of the press is to help produce a more informed electorate. A more informed citizenry will create a better and fuller democracy."27

In their treatise on the role of journalism in society, Bill Kovach and Tom Rosenstiel write that, "the primary purpose of journalism is to provide citizens with the information they need to be free and self-governing." ${ }^{.28}$ Kovach and Rosenstiel also argue that, "the notion of freedom of the press is rooted in independence and diverse voices. Only a press free of government censors can tell the truth. ${ }^{, 29}$

${ }^{25}$ Curran, James, Media and Democracy, Routledge, (2011), page 81

${ }^{26}$ Ibid, page 81

${ }^{27}$ Schudson, Michael, The Power of News, Harvard University Press, Cambridge, Massachusetts, (1995), page 204

${ }^{28}$ Kovach, Bill and Rosenstiel, Tom, The Elements of Journalism (revised and updated third edition), Three Rivers Press, New York, (2014), page 61 (e-book)

${ }^{29}$ Kovach, Bill and Rosenstiel, Tom, The Elements of Journalism (revised and updated third edition), Three Rivers Press, New York, (2014), page 127 (e-book) 
In a similar vein and expanding the case against censorship of the media, Levinson makes the following arguments:

First, being able to speak our minds makes us feel good. True, we tailor our words to civility, persuasion, kindness, or other purposes, but that is our choice. Censors claim the right to purge other people's talk - all the while insisting that it is for their own good.

Second, much censorship appears irrational and alarmist in retrospect because the reasons people choose and use words are vastly more interesting than the systems designed to limit them. It's not hard to make a list of absurdities - I'm particularly fond of a rash of state laws that forbid disparagement of agricultural products - but simplistic explanations and simple-minded responses are as dangerous as they are ditzy. In one of the few places that postmodern theory and common senses intersect, it is obvious that the meaning and perception of words regularly depend on such variables as speaker and spoken to, individual experience and shared history, and the setting, company, and spirit in which something is said. To give courts or other authorities the power to determine all this is, to put it mildly, mind-boggling.

Third, censorship is inimical to democracy. Cloaking ideas and information in secrecy encourages ignorance, corruption, demagoguery, a corrosive distrust of authority, and a historical memory resembling Swiss cheese. 
Open discussion, on the other hand, allows verities to be examined, errors to be corrected, disparagement to be expressed, and anxieties to be put in perspective. It also forces communities to confront their problems directly, which is more likely to lead to real solutions than covering them up.

Fourth, censorship backfires. Opinions, tastes, social values, and mores change over time and vary among people. Truth can be a protean thing. The earth's rotation, its shape, the origins of mankind, and the nature of matter were all once widely understood to be something different from what we know today, yet those who challenged the prevailing faith were mocked and punished for their apostasy. Banning ideas in an attempt to make the world safe from doubt, disaffection, or disorder is limiting, especially for people whose rights are routinely limited, since the poor and politically weak are the censor's first targets.

Finally, censorship doesn't work. It doesn't get rid of bad ideas or bad behavior. It usually doesn't even get rid of bad words, and history has shown repeatedly that banning the unpalatable merely drives it underground. ${ }^{30}$

To be effective in carrying out their important role in society, Schudson argues that journalists also have to be diligent in following principles and standards of journalistic objectivity. He describes objectivity as "a faith in 'facts,' a distrust of 'values' and a commitment to their segregation." He states that "facts, in this view, are assertions about

\footnotetext{
${ }^{30}$ Levinson, Nan, Outspoken: Free speech stories, University of California Press, Berkeley and Los Angeles, California, 2003, pages 18-19
} 
the world open to independent validation" which can "stand beyond the distorting influences of any individual's personal preferences." He adds that "values, in this view, are an individual's conscious or unconscious preferences for what the world should be; they are seen as ultimately subjective and so without legitimate claim on other people."31

Michael Gurevitch and Jay G. Blumler proposed the following eight key functions for the role of the press in a democratic society in their much-cited essay on the topic ${ }^{32}$ :

1. Surveillance of the sociopolitical environment, reporting developments likely to impinge, positively or negatively, on the welfare of citizens,

2. Meaningful agenda-setting, identifying the key issues of the day, including the forces that have formed any may resolve them,

3. Platforms for an intelligible and illuminating advocacy by politicians and spokespersons of other causes and interest groups,

4. Dialogue across a diverse range of views, as well as between power holders (actual and prospective) and mass publics,

5. Mechanisms for holding officials to account for how they have exercised power,

6. Incentives for citizens to learn, choose, and become involved, rather than merely to follow and kibitz over the political process,

\footnotetext{
${ }^{31}$ Schudson, Michael, Discovering the News: A Social History of American Newspapers, Basic Books, New York, (1978), pages 5-6

${ }^{32}$ Gurevitch, Miachel and Blumler, Jay G., Political Communication Systems and Democratic Values, 1990, pages 25-26 accessed online on 17 April 2017 at http://www.csub.edu/ mault/political\%20communication\%20sys.pdf
} 
7. A principled resistance to the efforts of forces outside the media to subvert their independence, integrity, and ability to serve the audience, and

8. A sense of respect for the audience member, as potentially concerned and able to make sense of his or her political environment.

All these aspects of the role of media in a conflict-ridden country such as Afghanistan, which is still in the process of overcoming war, ensuring peace and economic development, and consolidating its nascent democracy, are even more significant.

The United Nations recognizes that, "free, independent media will always be a cornerstone of democracy, transparency, accountability, development and respect for human rights." 33

The struggle for press freedom is a constant one. Therefore, and especially in postconflict or fragile states such Afghanistan, there is always a risk of backsliding in the area of press freedom and the development of independent media. This means that there must be certain guarantees and standards for press freedom.

The United Nations argues that in order to ensure the long-term viability of press freedom in post-conflict countries, in addition to the crafting of robust, democratic media laws, this requires "the creation of [an] independent regulatory structure," that an

\footnotetext{
${ }^{33}$ Secretary General's Message to Asia Media Summit, Beijing, 25 May 2010, accessed on online on 17 April 2017 at https://www.un.org/sg/en/content/sg/statement/2010-05-25/secretary-generals-message-asiamedia-summit-beijing
} 
"economically viable media is the only way forward to reasonable working conditions for journalists, including livable wages, which in turn is an important guarantor for transparency and anti-corruption among media professionals," that "the local media community should also be encouraged to discuss and enhance the professional standards of journalists, and to link with regional and international associations," and that the establishment of "independent journalists' associations should also be encouraged." "34

Legal guarantees alone are clearly not enough for the flourishing of democratic media. There are different examples of this in post-conflict or post-authoritarian cases, with different and sometimes mixed results. For example, despite robust legal guarantees for press freedom in Bosnia and Herzegovina in the 1990s, media there "remains deeply divided along ethnic lines." In addition, "different groups of media are controlled by different ethnic agendas through which all information and production is filtered. Ethnic allegiance, which does not need to be explicit in the media name ... serves as a key ideological reference point for all media content." ${ }^{, 35}$

\footnotetext{
${ }^{34}$ Supporting Media Legislation, United Nations Educational, Scientific and Cultural Organization (UNESCO), accessed online on 15 April 2017 at http://www.unesco.org/new/en/communication-andinformation/freedom-of-expression/dialogue-for-peace/media-in-conflict-and-post-conflict-situation-andcountries-in-transition//

${ }^{35}$ Sarajlic, Eldar, Media and Diversity in Post-Conflict Countries, The Anna Lindh Foundation, 2014 Report, http://www.annalindhfoundation.org/report/media-and-diversity-post-conflict-countries-eldarsarajlic, (accessed 20 June 2017)
} 
It is also clear that irresponsible media outlets can exacerbate societal tensions and even provoke violence, such as in the horrific case of the Rwandan genocide. Conversely, "responsible media can help repair and even strengthen a post-conflict society.",36

Scholars also emphasize the effective role independent media can play in peacebuilding efforts. For example, Christoph Spurk argues a two-fold role for media in peacebuilding. Firstly, he argues that "professional media" can contribute towards peacebuilding by "providing non-partisan news and reports, informing about different opinions and views, contributing to knowledge (mechanism, people, causes) about politics, local issues and conflictive issues, building well-informed and unbiased opinion and enabling people to take care of and decide on their own issues." Secondly, he posits, media can support peacebuilding by "improving knowledge of people in peace and conflict relevant issues such as elections, causes of conflict, inter-ethnic understanding, discrimination, truth commissions and war crimes, providing incentives for changing behavior or attitudes, countering false images or propaganda from biased media and enabling societies to deal with the past and build a common future." Spurk further argues that for the media to play its due role in peacebuilding, it requires the trust of the people without which this role "is in danger to be interpreted as poor propaganda and will be either ignored or discredited." 37

\footnotetext{
${ }^{36}$ Stroehlein, Andrew, An Overview of Media Development and Post-conflict Transition, International Crisis Group, https://www.crisisgroup.org/global/overview-media-development-and-post-conflicttransition-0, 3 April 2009, (accessed 22 June 2017)

${ }^{37}$ Spurk, Christoph, Media and Peace Building Concepts, Actors and Challenges, Swisspeace, November 2002 , page 5
} 
Elsewhere, Thania Paffenholz and Christoph Spurk also argue that media development is a necessary condition for the functioning of civil society groups. The absence of free and independent media deprives "civil society groups of one of their main communication channels to other civil society groups, the general public as well as government and state structures. ${ }^{, 38}$ In a related vein, Spurk makes the argument that media has a critical role in poverty reduction and development efforts in poor countries specifically by helping strengthen "social action that gives people confidence and organization." 39

At the same time, scholars argue that one of the most effective ways for the media to preserve their independence and role in society is a strong commitment to accountability on the part of the media itself. Julianne Schultz makes the case that media accountability can be "measured by acceptance of ethical codes; meaningful public accountability; providing diverse and challenging information; the methods by which it is obtained, presented and pursued." Schultz goes on to argue that, "without greater accountability, the media is little more than another powerful elite, detached from the public interest which gives it legitimacy. $" 40$

There is also an argument to be made about the importance of public sector support to the development of independent media in a context such as that in Afghanistan where government is often the strongest player. In fact, Paul Rothman posits that "political

\footnotetext{
${ }^{38}$ Paffenholz, Thania and Spurk, Christoph, Civil Society, Civic Engagement, and Peacebuilding, Conflict Prevention and Reconstruction, Social Development Department, World Bank, October 2006, page 11, http://siteresources.worldbank.org/INTCPR/Resources/WP36_web.pdf, (accessed 15 February 2018)

${ }^{39}$ Sparks, Colin, Globalization, Development and the Mass Media, Sage Publications, 2007, page 226

${ }^{40}$ Schultz, Julianne, Reviving the Fourth Estate: Democracy, Accountability and the Media, Cambridge University Press, (1998), pages 9-10
} 
support for the media as a pillar of democratic governance is a prerequisite for the passage of laws that create a sustainable and independent media sector that contributes to the overall quality of governance.",41

At this stage, I feel compelled to note that any theoretical framework used for assessing the development of independent media in Afghanistan must take into account the country’s unique situation at once as a post-authoritarian yet conflict-ridden and fragile state that faces a number of key structural challenges to its survival and progress. The three major fundamental challenges the Afghan state faces, which would affect the trajectory of the growth and development of Afghan media directly, are: 1) the ongoing war between the Afghan government and a multitude of non-state groups including the Afghan Taliban, which poses an ongoing threat to the survival of the nascent democratic order in the country; 2) fledgling government institutions which are still being developed at a time when robust institutions are required to ensure the effective enforcement of the rule of law and justice; and 3) one of the weakest and least developed economies in the world which perpetuates continuous dependence on foreign assistance.

Therefore, it is important to note that the theoretical framework above might best be applied to a post-conflict or newly democratizing society that is not suffering from the additional structural ills that Afghanistan is faced with. Nonetheless, I believe the framework outlined here, including the key requirements for the development of an independent media in a violence-prone volatile yet democratizing post-authoritarian

\footnotetext{
${ }^{41}$ Rothman, Paul, The Politics of Media Development: The Importance of Engaging Government and Civil Society, Centre for International Media Assistance, September 2015, http://www.cima.ned.org/wpcontent/uploads/2015/08/CIMA-The-Politics-of-Media-Development.pdf, (accessed 15 February 2018)
} 
context, is robust enough to allow for a broad assessment of the development of independent Afghan media and its role in sustaining and consolidating Afghanistan's nascent democracy.

With the above theoretical framework as a guide, the research project will utilize the United Nations Educational, Scientific and Cultural Organization (UNESCO's) five Media Development Indicators (MDIs), adopted by the UN organization in 2008, in order to carry out the first baseline assessment of media development in Afghanistan since $2001 .^{42}$ The direct relevance of using this framework also lies in the fact that these indicators have been specifically developed and agreed upon by the UN for "developing countries and countries in transition., ${ }^{43}$ Afghanistan clearly falls into the category of a country in transition.

\subsection{Methodology}

The thesis project will utilize the following five key "media development categories" to test the development of Afghanistan's media sector since the collapse of the Taliban regime in late 2001 against: $^{44}$

\footnotetext{
${ }^{42}$ United Nations Educational, Scientific and Cultural Organization (UNESCO) statement on press freedom (Retrieved on 31 August 2015 from the UNESCO website at: http://www.unesco.org/new/en/communication-and-information/freedom-of-expression/press-freedom/)

${ }^{43}$ Decision on Media Development Indicators adopted by the IPDC (International Program for the Development of Communication) Intergovernmental Council at its 26th session, UNESCO Headquarters, Paris, 26 March 2008, http://www.unesco.org/new/fileadmin/MULTIMEDIA/HQ/CI/CI/pdf/ipdc2008 decision_on indicators.pdf (Accessed 13 September 2015)

${ }^{44}$ Media Development Indicators: A Framework for Assessing Media Development, UNESCO, 2008, p. 36-37 (e-book)
} 
CATEGORY 1: A system of regulation conducive to freedom of expression, pluralism and diversity of the media: existence of a legal, policy and regulatory framework which protects and promotes freedom of expression and information, based on international best practice standards and developed in participation with civil society.

CATEGORY 2: plurality and diversity of media, a level economic playing field and transparency of ownership: the state actively promotes the development of the media sector in a manner which prevents undue concentration and ensures plurality and transparency of ownership and content across public, private and community media.

CATEGORY 3: media as a platform for democratic discourse: the media, within a prevailing climate of self-regulation and respect for the journalistic profession, reflects and represents the diversity of views and interests in society, including those of marginalised groups. There is a high level of information and media literacy.

CATEGORY 4: professional capacity building and supporting institutions that underpins freedom of expression, pluralism and diversity: media workers have access to professional training and development, both vocational and academic, at all stages of their career, and the media sector as a whole is both monitored and supported by professional associations and civil society organisations.

CATEGORY 5: infrastructural capacity is sufficient to support independent and pluralistic media: the media sector is characterised by high or rising levels of public 
access, including among marginalised groups, and efficient use of technology to gather and distribute news and information, appropriate to the local context.

These five categories are divided into around 50 more specific indicators, each of which will be used to measure various aspects of the development of the Afghan media sector.

Each of the five key categories above will be shaped into separate chapters based on the relevant findings and discussions.

As stated earlier, this assessment will be the first of its kind about the development of free media in Afghanistan and will thus create a broad baseline for more detailed assessments and studies in the future.

It will also aim to expose key challenges and threats facing the development of the independent media sector and journalists in Afghanistan and help identify potential remedies and interventions by all the key stakeholders, including the government, Afghan civil society and international supporters. This normative section will be added in order to offer recommendations for strengthening the prospects of long-term survival and further development of press freedom in Afghanistan as the country moves deeper into its socalled Transformation Decade of 2015-2024 during which its expected not only to 
preserve and protect the gains of the past decade but also achieve increasing financial and fiscal self-reliance as international development assistance levels continue their decline. ${ }^{45}$

To date, these UNESCO MDIs have been used in assessing media development in the following 14 countries: Bhutan, Croatia, Ecuador, Egypt, Gabon, Jordan, Mozambique, Nepal, Palestine, Maldives, Timor-Leste, Tunisia, Libya, South Sudan. No study has been carried out in Afghanistan using these MDIs.

In addition to the use of the MDIs as the primary framework for conducting this project, the methodology will also include primary in-depth interviews and review of literature on Afghan media in the post-Taliban years including books, articles, studies and surveys by Afghan and international authors and organisations.

The in-depth interviews were conducted with some of the main figures on the media scene in Afghanistan, including reporters and editors of major media outlets, who have played prominent roles over the past 15 years since the fall of the Taliban regime. Interviews were conducted with research participants both in Kabul and in the provinces. To minimise any potential risks to research participants, their responses during the interviews are cited anonymously, meaning that names or any other direct personal identifying information are not mentioned in the research project.

\footnotetext{
${ }^{45}$ Conclusions of the Conference on Afghanistan and the International Community: From Transition to the Transformation Decade, Bonn Conference, Bonn, Germany, 5 December 2011, Ministry of Foreign Affairs, Afghanistan, http://mfa.gov.af/Content/files/Second\%20Bonn\%20Conference\%202011\%20Communique.pdf , (Accessed 27 April 2017)
} 
The project also utilises relevant published accounts in Afghanistan in Pashto and Dari the country's two national official languages - as well as relevant reports and discussions in the country's leading media outlets.

The study will establish a first baseline that can be used on an annual, or other regular, basis to measure the future progress of the media sector in Afghanistan, which will help identify challenges and gaps that need to be addressed by the Afghan state, the media community as well as governments and NGOs in the international community providing support and assistance to the media sector in Afghanistan.

This research project was cleared by Carleton University Research Ethics Board-A (CUREB-A Clearance \#106602). 


\section{Chapter: HISTORY OF AFGHAN MEDIA}

This chapter will offer an overview of the history of Afghan media from the establishment of the first newspaper in the country in 1873 to the fall of the Taliban regime in late 2001. The overview will look at how different governments approached the media sector, how they contributed to or hindered the development of the sector and how much freedom they afforded to journalists. Throughout, the chapter will also look at the development of the legal framework for the media sector during the reign of various governments.

\subsection{The beginning of Afghan Media}

The first Afghan media outlet, a 16-page broadsheet weekly newspaper called Shams-unNahar, started publication in 1873 in Kabul. ${ }^{46}$ The initiative was taken by the then Afghan king Amir Shir Ali Khan at the urging of the famous Afghan philosopher Sayed Jamaluddin Afghani who advocated for the enlightenment, development and self-reliance of Muslim societies. $^{47}$

Shams-un-Nahar mainly published articles on domestic news and articles praising King Shir Ali Khan's social, economic and military reform efforts. In addition, it also published news from outside Afghanistan, mainly from neighbouring countries. In an article published in its tenth edition, the newspaper said its publication had encouraged

\footnotetext{
${ }^{46}$ Ahang, Mohammad Kazim, A history of media in Afghanistan, 1977, Kabul, page 9, Historical Society of Afghanistan, Ministry of Information and Culture

${ }^{47}$ Partaw Naderi, The condition of media in Afghanistan, page 4, Afghanistan Civil Society Foundation, Maiwand Printing Press, 2007, Kabul
} 
“the country's citizens and elites to turn their faces to knowledge and excellence, and it has engendered love of reading newspapers and benefitting from it." ${ }^{48}$

This first Afghan newspaper contained three broad sections: 1) government announcements, 2) domestic news, and 3) foreign news. Foreign news mainly came from regional and international newspapers that reached Kabul, including Sunday Times, Punjab Society from Lahore, Sayed-ul-Akhbar from Delhi, St. Petersburg from Russia, Bombay Gazette and Iran News from Tehran. ${ }^{49}$

Shams-un-Nahar was born during a period in Afghanistan and the region when rulers started moving away from total despotism to gradual reforms. For example, Amir Shir Ali Khan consolidated reforms, including in the military and governance spheres, and "further distanced the state from strict patrimony: he continued to build a professional army and delegated administration not to his sons but to ministers of diverse origins."

Following a full decade of publication, Shams-un-Nahar came to an end with the invasion of Afghanistan by Britain in $1887 .{ }^{51}$ Although the British invasion triggered a wave of national resistance against the invaders, it also resulted in long years of internal tumult. One casualty of this period was the country's nascent press; it took 28 years between the closure of Shams-un-Nahar and the publication of the country's next newspaper, Siraj-ul-

\footnotetext{
${ }^{48}$ Ahang, Mohammad Kazim, A history of media in Afghanistan, 1977, Kabul, page 13, Historical Society of Afghanistan, Ministry of Information and Culture

${ }^{49}$ Ibid, pages 16-19

${ }^{50}$ Rubin, Barnett, The Fragmentation of Afghanistan: State Formation and Collapse in the International System, Second Edition, page 48, Yale University Press, 2002

${ }^{51}$ Ibid, page 28
} 
Akhbar, in $1906 .^{52}$ Even then, Siraj-ul-Akhbar was banned after the publication of its first issue, most believe at the urging of the British rulers in next-door India. ${ }^{53}$ The British clearly feared an informed populace in a strategic land.

It took another five years - and the ascension to the throne of Afghanistan's independence king, Amanullah Khan - before Siraj-ul-Akhbar resumed publication in 1911 under the new name of Siraj-ul-Akhbar Afghani. This time, the newspaper was led by Mahmoud Tarzi, a leading intellectual of his time, a future foreign minister of the country and the young king's father-in-law, and later known as the father of journalism in Afghanistan.

In its very first issue, the paper's editorial emphasized the importance of news and information. On the front page, it declared: "It is an apparent and clear matter that media in this present age have stood up as the tongue of states and nations. In the present time, except for barbarian and primitive ethnic groups, there is no state or nation that does not possess its own newspaper." The article went on to underline the importance of news by drawing a contrast between knowledge and ignorance. "Akhbar (news) is the plural of khabar (news) whose opposite is bekhabari (ignorance). Therefore, based on the principle

\footnotetext{
${ }^{52}$ Ahang, Mohammad Kazim, A history of media in Afghanistan, 1977, Kabul, page 39, Historical Society, Ministry of Information and Culture

${ }^{53}$ Partaw Naderi, The condition of media in Afghanistan, page 10, Afghanistan Civil Society Foundation, Maiwand Printing Press, 2007, Kabul
} 
that everything is recognized by reference to its opposite, it becomes obvious what difference there is between being informed and being ignorant!",54

Siraj-ul-Akhbar was reborn at a time when Afghanistan's foreign policy was still subject to the whims of the British empire. The paper, therefore, became a bastion of anticolonial nationalistic writing, and crystallized the growing national movement toward complete independence, which finally occurred in August 1919 following the Third Anglo-Afghan War. ${ }^{55}$ Amanullah also established a series of other papers both in Kabul and in the provinces and launched the country's first radio station in 1925, which "inaugurated a new age in the development of mass media in Afghanistan."

In addition, the publication of Siraj-ul-Akhbar, and a children's paper called Siraj-ulAkhbar Atfal (Children's Siraj-ul-Akhbar) in 1917, coincided with the establishment of the first modern schools in the country. ${ }^{57}$ Other publications that came out during this period included Haqiqat, Anis and Habib-ul-Islam established in Kabul in 1925, 1928 and 1929 , respectively. ${ }^{58}$

Thus, media during this period - ranging from newspapers to magazines and women's publications as well as the country's first radio station - created "fresh and progressive

\footnotetext{
${ }^{54}$ Introduction, Siraj-ul-Akhbar Afghani, $1^{\text {st }}$ issue, page 1, 5 October 1911, Kabul (accessed from the archives of the Afghanistan Centre at Kabul University)

${ }_{55}$ Partaw Naderi, The condition of media in Afghanistan, pages 10-12, Afghanistan Civil Society Foundation, Maiwand Printing Press, 2007, Kabul

${ }^{56}$ Saikal, Amin, Modern Afghanistan: A History of Struggle and Survival, page 77, I.B. Taurus, London, 2004

${ }^{57}$ Partaw Naderi, The condition of media in Afghanistan, page 14, Afghanistan Civil Society Foundation, Maiwand Printing Press, 2007, Kabul

${ }^{58}$ Accessed through the archives of the Afghanistan Centre at Kabul University, Kabul, November 2017
} 
ideas" for the first time.$^{59}$ In addition to opening the space for media - with the first constitutional guarantee for media getting enshrined in the 1923 constitution - and launching free public education, King Amanullah also made a push for rapid modernization of Afghanistan. "The most important vehicle for the program of modernization was the newspaper Siraj-ul-Akhbar, founded by Mahmud Tarzi, who had become acquainted while in exile with the works of thinkers like Muhammad Abduh and Jamaluddin al-Afghani, introduced the ideology of Islamic modernism to Afghanistan."

The young king introduced modern urban planning, passed various laws, modernized the military and went against his country's entrenched traditionalism. For example, he decreed away the requirement for women to wear veils in public, mandated the wearing of Western dress by men and appeared in public with his wife, Queen Suraya. The result of all of these hasty actions was that, "Amanullah alienated tribal leaders by revoking their privileges; his modernization schemes had depleted the treasury; and he could not secure adequate funding from external sources." ${ }^{, 61}$ Amanullah's rule came to an end in 1929 following a series of violent revolts and uprisings by various tribes, religious mullahs and other opportunists who were opposed to his modernization and reform programs. ${ }^{62}$

\footnotetext{
${ }^{59}$ Ahang, Mohammad Kazim, Afghan Media in the First Decade of Independence, page 110, Afghanistan Journalists Union, Kabul, 1990

${ }^{60}$ Rubin, Barnett, The Fragmentation of Afghanistan: State Formation and Collapse in the International System, Second Edition, page 54, Yale University Press, 2002

${ }^{61}$ Saikal, Amin, Modern Afghanistan: A History of Struggle and Survival, page 13, I.B. Taurus, London, 2004

${ }^{62}$ Ibid, page $80-88$
} 
A major casualty of the ouster of Amanullah's reign was the media sector. All newspapers were summarily closed down. ${ }^{63}$ Worse still, a number of prominent journalists, including the publisher of Anis, one of the leading media outlets under Amanullah, which has continued to the present day, were murdered. ${ }^{64}$

Between the collapse of Amanullah Khan's government and the evolution of the country's political system into a constitutional monarchy in 1964 , the media sector went through a series of upheavals. For instance, despite back-to-back repressive regimes under various leaders during that period, some steps were taken that contributed to the slow but steady strengthening of the media sector. One of these was the establishment of the first government department responsible for media affairs and the first official news agency, Bakhtar News Agency, at the same time in $1939 .{ }^{65}$ The media department went on to develop into the present-day Ministry of Information and Culture while Bakhtar is still the only Afghan government news agency.

The 40-year reign of King Zahir Shah, from 1933 to 1974 when he was ousted in a palace coup, offers a perfect illustration of the ups and downs in the development of the media sector during the post-Amanullah years. Zahir Shah ascended the throne at the age of 19 on the day his father, King Nader Shah, was assassinated in 1933 in Kabul by a student. Largely because of the young king's age and lack of preparedness to rule, two of his

\footnotetext{
${ }^{63}$ Ibid, page 96

${ }^{64}$ Partaw Naderi, The condition of media in Afghanistan, page 15, Afghanistan Civil Society Foundation, Maiwand Printing Press, 2007, Kabul

${ }^{65}$ Bakhtar News Agency, Ministry of Information and Culture, http://moic.gov.af/fa/page/1290/2111, (accessed 15 December 2017)
} 
influential uncles and, later, a cousin ruled the country for him for 30 years until $1963 .^{66}$ In order to ensure the survival of their dynasty following the assassination of their brother, Kind Nader, the new king's uncles “also tightened their dynastical suppression of all forms of opposition. ${ }^{, 67}$ A clampdown on the media was part of this suppression.

For example, "under pressure from the growing strata of merchant capitalists, liberalminded intellectuals, western-educated state officials and other professionals, the government gradually began to open up the political space." One of the key steps in this regard was the passing of the Law on the Press in 1951, "sanctioning the creation of privately owned newspapers and abolishing preliminary censorship." However, these freedoms were abruptly taken away the following year in 1952 when the government banned all political parties and "closed down practically all independent newspapers."68

This situation continued without much change until Zahir, by now a more confident and assertive monarch and supportive of a transition to democracy, led the passing of a new constitution in 1964. Severely limiting the role of the royal family in politics, opening space for the formation of political parties and allowing for the election of a democratic parliament, and decreeing the independence of the mass media, the new constitution was hailed as "possibly the finest Constitution in the Muslim world." 69

\footnotetext{
${ }^{66}$ Saikal, Amin, Modern Afghanistan: A History of Struggle and Survival, page 106, I.B. Taurus, London, 2004

${ }^{67}$ Ibid, pages 104

${ }^{68}$ Ibid, page 115-116

${ }^{69}$ Dupree, Louis, Afghanistan and the Unpaved Road to Democracy, Journal of the Royal Central Asian Society, 56(3), October 1969, page 273, quoted in Saikal, Amin, Modern Afghanistan: A History of Struggle and Survival, page 146, I.B. Taurus, London, 2004
} 
During this period, parallel to the formation of various political parties, many newspapers and other publications also emerged. Newspapers during this so-called Decade of Democracy (1964-1974) could be divided into the broad three categories of government newspapers, newspapers published by the new political parties and independent newspapers. All of these media outlets played an important role in the political socialization of the youth and in raising awareness mainly among the urban populace. ${ }^{70}$ "The free press and media, the freedom of travel and associations probably raised the Afghan consciousness to an unparalleled extent. Afghans learned more about their rights as individuals, groups, parties and democracy as a whole in those ten years, than in the previous one hundred years." ${ }^{, 71}$ The expansion of the independent media sphere also allowed the populace an opportunity "to express themselves not just in a village or tribal Jirga to one another but through the media to the whole country., ${ }^{, 72}$

Although the passing of the new Constitution opened the way for the flourishing of independent media outlets, including those published by the various leftist and rightist political parties that emerged, the overall democratic political transition didn't succeed as planned. "The persisting patrimonial character of the state in Afghanistan proved detrimental to an experiment with democracy," noted Amin Saikal. "Constitutional law, freedom of speech and association, regular elections to the legislature, political parties and organizations, and other trappings of modern liberalism were superfluous under

\footnotetext{
${ }^{70}$ Partaw Naderi, The condition of media in Afghanistan, page 22-25, Afghanistan Civil Society Foundation, Maiwand Printing Press, 2007, Kabul

${ }^{71}$ Misdaq, Nabi, Afghanistan: Political Frailty and External Interference, page 81, Routledge, New York, 2006

72 Ibid, page 229
} 
conditions where all real mechanisms of social control remained firmly in the hands of the Mohammadzai clan." At the same time, "the entire discourse and praxis of 'democratization' was confined to the still numerically insignificant urban establishment, so there was no pressure from the bulk of the populace to follow this path."73

The new constitution "and the ten years of unchecked press and media freedom that followed it opened a 'Pandora's box' of many parties and groups, from Afghan nationalists and Islamists, to social democrats and many different shades of leftist movements, all making their debut on the political stage." 74

The political upheaval that the passing of the 1964 constitution had wrought eventually resulted in a coup against King Zahir Shah by his cousin, brother-in-law, and onetime prime minister, Daoud Khan in 1974. Daoud promptly "declared a state of emergency, disbanded parliament, suspended the 1964 constitution, banned all forms of opposition organizations, propaganda and agitation, and closed all private newspapers and magazines.",75

However, paradoxically enough, despite re-imposing censorship on the mass media and banning independent media outlets, Daoud expanded the number and reach of

\footnotetext{
${ }^{73}$ Saikal, Amin, Modern Afghanistan: A History of Struggle and Survival, page 168, I.B. Taurus, London, 2004

${ }^{74}$ Misdaq, Nabi, Afghanistan: Political Frailty and External Interference, page 80, Routledge, New York, 2006

${ }^{75}$ Saikal, Amin, Modern Afghanistan: A History of Struggle and Survival, page 173, I.B. Taurus, London, 2004
} 
government publications in Kabul and, more significantly, in the provinces during this period. In 1974, Daoud also introduced television to the country for the first time.

Daoud's relations with the Afghan communists of the People's Democratic Party of Afghanistan (PDPA), factions of which had been instrumental in his coup, became increasingly strained. This led into an intensifying cycle of pressure from Daoud against the communists on the one hand and louder public opposition and agitation by the communists on the other. To Daoud's misfortune, the communists, who had deeply infiltrated the armed forces with their sympathizers, launched a bloody coup in 1978. Daoud and almost his entire family and close associates were murdered. ${ }^{76}$

The blood-stained communist coup was a precursor to the more than two decades of Soviet invasion, Western-backed anti-Soviet jehad and Taliban rule that followed. During this period, the country's media sector was firmly under state control and used almost exclusively to propagate regime rhetoric, which ranged from Marxisim-Leninism and nationalism under the PDPA to religious fundamentalism and obscurantism under the Mujahideen and Taliban regimes. ${ }^{77}$

The Taliban, who captured the capital Kabul in 1996 following swift military victories throughout the country, went a step further in their suppression. Any traces of non-regime activities, including in the media sector, were eliminated.

\footnotetext{
${ }^{76}$ Saikal, Amin, Modern Afghanistan: A History of Struggle and Survival, page 183, I.B. Taurus, London, 2004

${ }^{77}$ Partaw Naderi, The condition of media in Afghanistan, pages 29-34, Afghanistan Civil Society Foundation, Maiwand Printing Press, 2007, Kabul
} 
The regime "implemented an extreme interpretation of the Sharia or Islamic law that appalled many Afghans and the Muslim world." This included not only a complete shutdown of non-regime media outlets but included a ban on "every conceivable kind of entertainment including music, TV, videos, cards, kite-flying and most sports and games." ${ }^{, 78}$ Also, the regime "closed down girls' schools and banned women from working outside the home, smashed TV sets, forbade a whole array of sports and recreational activities and ordered all males to grow long beards." ${ }^{.79}$ To prove their totally different, retrograde approach to the media, the regime even renamed Radio Kabul as Radio Shariat. ${ }^{80}$

\subsection{Conclusion}

The 9/11 attacks and the retaliatory American attack against Afghanistan, focused the West's attention disproportionately on the Taliban and Mujahideen periods in Afghanistan. In the years since those attacks in New York and Washington and the toppling of the Taliban regime in a US-led military campaign, most of the Western media coverage has dwelt on terrorism and extremism, both of which are very recent modern phenomena. Conversely, very little attention has been given to the history of Afghanistan, with its complexity in a highly volatile and historically significant part of the world. This includes the evolution of the Afghan media sector.

\footnotetext{
${ }^{78}$ Rashid, Ahmed, Taliban: Islam, Oil and the New Great Game in Central Asia, page 2, I.B. Tauris, 2002

${ }^{79}$ Ibid, page 29

${ }^{80}$ Ibid, page 50
} 
As this chapter has demonstrated, the history of Afghan media is not limited to the postTaliban period or the so-called Decade of Democracy but has much deeper roots, predating the country's full independence in 1919 by almost half a century. The first media outlets - from Shams-un-Nahar to Siraj-ul-Akhbar and their contemporary publications - galvanized national movements for reforms and, later, independence. Various governments and regimes over the years used the expansion of infrastructure, including roads and public services such as education as well as mass media to "strengthen Afghan culture and identity.", 81

The findings also show that the reforms of Amanullah Khan, including the first ever constitutional guarantee for press freedom, the reforms of the Decade of Democracy and the unprecedented growth and development of the media sector in the post-Taliban period are the three key historic points in the context of the historical development of independent media in Afghanistan.

In addition, the findings in this chapter show that the more recent post-independence history and evolution of Afghan media up until 2001 can be described as being largely under state control and repression but with occasional periods of freedom and legal protection.

However, the dark period of the civil war and Taliban misrule between 1992 and 2001 stands in vivid contrast even to the worst periods of media repression during other

${ }^{81}$ Misdaq, Nabi, Afghanistan: Political Frailty and External Interference, page 72, Routledge, New York, 2006 
restrictive periods in the country's history. The closure of this tragic period for the country, marked with the overthrow of the Taliban regime in late 2001, opened a new era for the revival, growth and development of the Afghan media sector. This thesis aims to tell that story; to assess the current state of the news media in Afghanistan; and to examine the prospects for the news media as civic institutions in the context of the UN's Media Development Indicators. 


\section{Chapter: LEGAL AND POLICY FRAMEWORK}

This chapter will review and assess the Afghan news media in light of Category 1 of the UN's Media Development Indicators: Legal and policy framework.

The chapter outlines the legal framework for the operation of the media sector in Afghanistan. It will focus on the guarantees for press freedom and freedom of expression in the current constitution. The chapter will delve in greater depth into the two key pieces of Afghan legislation related to the media sector, namely the Mass Media Law and a more recent Access to Information Law. In doing so, the chapter will discuss the various iterations and amendments to the Mass Media Law and the reasons behind the changes. The chapter will examine various key issues relevant to legal protections and guarantees for the operation of an independent media. These will include a look at the role of civil society groups in shaping public policy in the media sector, the ability of journalists to protect their sources, the question of censorship in the Afghan media, and whether or not the legal framework as a whole promotes or hinders the growth and development of pluralistic media. The chapter will also explore how successfully the legal guarantees and protections for media are upheld in practice. In assessing all of these topics, the discussion in the chapter will rely on interviews conducted specifically for this project.

\subsection{Legal Framework}

\subsubsection{Freedom of expression is guaranteed in law and respected in practice}

The constitutional and other legal guarantees for press freedom in Afghanistan seem robust. The constitution, ratified in 2004, three years after the collapse of the Taliban 
regime, provides a broad basis for freedom of expression and press freedom in its Article 34:

"Freedom of expression shall be inviolable. Every Afghan shall have the right to express thoughts through speech, writing, illustrations as well as other means in accordance with provisions of this constitution. Every Afghan shall have the right, according to provisions of law, to print and publish on subjects without prior submission to state authorities. Directives related to the press, radio and television as well as publications and other mass media shall be regulated by law. ${ }^{, 82}$

This constitutional language flows from the inclusion of respect for the Universal Declaration of Human Rights in the preamble of the constitution itself. ${ }^{83}$ This specific article of the constitution is also taken as the strongest element of the legal guarantee for freedom of expression and press freedom in Afghanistan, especially by journalists and media freedom advocates. ${ }^{84}$

Following the promulgation of the constitution, Afghanistan saw the enactment of four media laws in 2002, 2004 and 2009. The first media law, simply called the Media Law of Afghanistan, came into being in February 2002, only three months after the fall of the Taliban regime in November 2001. This first post-Taliban law guaranteed "the right to

\footnotetext{
${ }^{82}$ Constitution of the Islamic Republic of Afghanistan, Article 34, Ministry of Justice, Kabul, 2004, Page 10

${ }_{83}^{83}$ Constitution of the Islamic Republic of Afghanistan, Preamble, Ministry of Justice, 2004, page 1

${ }^{84}$ Author interviews with several journalists, civil society and press freedom activists based in Kabul during May and July 2017
} 
freedom of thought and expression." ${ }^{85}$ The law also provided for "ensuring a conducive ground wherein the citizens of the country can express their thoughts and feelings through speech and writing, drawing, photography/video, tape recording, theatre, acting and other literary and artistic phenomena and be able to print and publish materials. ${ }^{\prime 86}$ At the same time, the law contained provisions that could be interpreted as limiting freedom of expression and press freedom. For example, the law contained a chapter detailing "prohibited publications" which included anything that would "cause disrespect towards Islam or other religions," "cause defamation to individuals," "result in the corruption of public morality" or "aim to weaken the army." ${ }^{87}$ In addition to specifying heavy monetary fines in cases of such violations, the law also provided for the possible punishment of violators in accordance with the provisions of Sharia law. ${ }^{88}$

Two years later, in March 2004, the Transitional Government of Afghanistan, which had succeeded the Interim Administration of Afghanistan the previous year, issued a new law based on the country's new constitution which was adopted by a Loya Jirga or Grand Assembly in January 2004. This iteration of the media law, called the Mass Media Law of Afghanistan, broadened and strengthened the legal guarantees for freedom of expression and press freedom. The new law provided for "the growth and support of

\footnotetext{
${ }^{85}$ Media Law of the Interim Administration of Afghanistan, Article 1, Ministry of Justice, Kabul, 24 January 2002, http://moj.gov.af/content/files/OfficialGazette/0701/OG_0800.pdf (Retrieved 15 July 2017), page 1

${ }^{86}$ Media Law of the Interim Administration of Afghanistan, Article 2, Ministry of Justice, Kabul, 24 January 2002, http://moj.gov.af/content/files/OfficialGazette/0701/OG_0800.pdf (Retrieved 15 July 2017), page 1

${ }^{87}$ Media Law of the Interim Administration of Afghanistan, Articles 30, Ministry of Justice, Kabul, 24 January 2002, http://moj.gov.af/content/files/OfficialGazette/0701/OG_0800.pdf (Retrieved 15 July 2017), page 19

${ }_{88}^{8}$ Media Law of the Interim Administration of Afghanistan, Articles 39, Ministry of Justice, Kabul, 24 January 2002, http://moj.gov.af/content/files/OfficialGazette/0701/OG_0800.pdf (Retrieved 15 July 2017), page 24
} 
freedom of thought and expression, defending the rights of journalists and ensuring conditions for their free activities," "growth and development of free, independent and pluralistic mass media," "providing adequate grounds for the expression of thought and feeling by the country's citizens through speech, writing, drawing, photography/video, tape recording, acting, movement and other academic, literary and artistic phenomena and printing and publishing," "respecting the principle of freedom of expression and mass media enshrined in the Universal Declaration of Human Rights (while) taking into account the tenets of the holy religion of Islam," "help towards the sound growth of mass media so that they become effective tools of culture, and reflect the views of people in an honest and useful manner." ${ }^{89}$ This new law took away the requirement for receiving prior written permission from the government for the establishment of print media outlets (article 9), and limited the list of prohibited matters to anything disrespectful of Islam or other religions and harm to personal reputation (article 31).

Following parliamentary elections in 2005 , the new parliament brought amendments to this law and enacted the Mass Media Law of the Islamic Republic of Afghanistan of $2005 .^{90}$ This law contained similar guarantees and protections for press freedom as the 2004 law but also made a clear reference to the need for the observance of "the journalistic standards, principles and values of honesty, impartiality and balance." $" 11$

\footnotetext{
${ }^{89}$ Mass Media Law of the Transitional Government of Afghanistan, Article 2, Ministry of Justice, 2004, http://moj.gov.af/content/files/OfficialGazette/0801/OG_0824.pdf (Retrieved 15 July 2017), page 3-4

${ }^{90}$ Mass Media Law of the Islamic Republic of Afghanistan, Ministry of Justice, 2005, http://moj.gov.af/content/files/OfficialGazette/0801/OG_0871.pdf, (Retrieved 15 July 2017)

${ }^{91}$ Mass Media Law of Afghanistan, Article 2, Ministry of Justice, 2005, (Retrieved 15 July 2017), http://moj.gov.af/content/files/OfficialGazette/0801/OG_0871.pdf, page 3
} 
Apart from the differences outlined above, the texts of the four different media laws passed in Afghanistan since 2002 largely converge on similar guarantees and protections for freedom of expression and press freedom. What accounts for the biggest difference among the four laws, especially between the 2009 law and the one preceding it is the type of mechanism for overseeing the implementation of the law and, more specifically, addressing media violations.

The 2005 law established a High Media Council (article 28) to craft a long-term government media policy and to appoint members of three additional bodies for managing licensing for private media outlets, overseeing the state-owned Radio Television Afghanistan, and the state-owned Bakhtar News Agency. Additionally, and controversially, the law created a so-called Commission for Assessing Complaints and Addressing Media Violations under the control of the Ministry of Information and Culture, the main Afghan government body dealing with the media sector. Although membership of this commission included representatives from the Afghanistan Independent Human Rights Commission, the national lawyers' association, the national journalists' union, the national cinematographers association and the national women's association (article 32), Afghan journalists and media advocates opposed it from the outset, and carried out sustained lobbying to remove the commission from the law. ${ }^{92}$ They all feared undue government influence as long as the commission remained under the auspices of the Minister of Information and Culture.

\footnotetext{
92 Author interviews with two Kabul-based Afghan media lawyers and press freedom activists who worked on the passage of the 2009 Mass Media Law, 15 July 2017
} 
Largely as a result of advocacy on the part of media organizations and a few pro-media members of parliament, the 2009 media law subsequently removed the media violations commission and instead established a new body, the so-called Mass Media Commission, to oversee the media sector and address complaints of violations against the media (article 42). Despite the enactment of the new law, the government, specifically its Ministry of Information and Culture, for years did not constitute the new Mass Media Commission and instead worked through the legally defunct Commission for Assessing Complaints and Addressing Media Violations. For instance, NAI Supporting Open Media in Afghanistan, called the media violations commission illegal and repeated the Afghan media community's call for its abolishment in accordance with the amended law passed in $2009 .{ }^{93}$

However, instead of implementing the 2009 law, and just before the 2014 elections that resulted in the first democratic peaceful transfer of power in the recent history of Afghanistan, the government requested the Wolesi Jirga or lower house of the Afghan parliament to revive the Commission for Assessing Complaints and Addressing Media Violations, which it subsequently did through a two thirds majority vote in January 2015, nearly five months after the establishment of the new government. ${ }^{94}$

As an Afghan war reporter with ten years of experience put it, the complaints and violations commission has not yet taken any step to restrict press freedom in the country:

\footnotetext{
93 The media community in Afghanistan is tired of the existence of the illegal commission for addressing

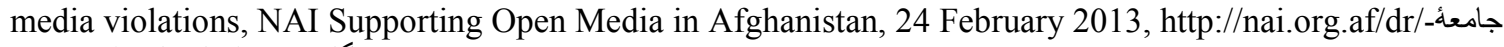
(خبرنكارى-در -افغانستان، -از _موجود (Accessed 15 July 2017)

${ }^{94}$ Amendment of the media law is against the constitution, Ava Press, 29 January 2015, http://avapress.com/vdccpeqsi2bqxs8.ala2.html, (Accessed 15 July 2017)
} 
"The commission dealing with media violations is at the Ministry of Information and Culture but overall when you see that the media write and the media broadcast different things and the way they criticize the government and don't get punished through this commission, the situation is good. $" 95$ Despite this, Afghan press freedom activists are still focused on doing away with this body, which they see as a potential restriction on press freedom in Afghanistan, specifically as a mechanism that gives too much control to the government Minister of Information and Culture as head of the media complaints commission, which they fear an anti-press freedom minister in the future can abuse. ${ }^{96}$

Notwithstanding the serious concerns of the Afghan journalists community regarding the media complaints commission, reporting prohibitions related to religious matters and vague terminology on national security, Afghan journalists and media activists agree the overall legal framework for press freedom in the country is strong. For instance, a veteran Afghan journalist and press freedom activist who heads a journalists protection organization and who has relentlessly campaigned for greater rights and freedoms for journalists in the country, says the Afghan legal framework for the functioning of the media is "extremely liberal ... and the state is not imposing unwarranted legal restrictions on the media." 97

The editor in chief of one of the leading dailies based in Kabul spoke favourably about the openness of the Afghan media legal framework in comparison to the situation in neighbouring countries. "The one strong reason for the growth and development of the

\footnotetext{
95 Author interview with Afghan war reporter based in Kabul, 30 April 2017

${ }^{96}$ Author interviews with two Kabul-based Afghan media lawyers and press freedom activists who worked on the passage of the 2009 Mass Media Law, 15 July 2017

${ }^{97}$ Author interview with Kabul-based press freedom activist and media safety specialist, 8 July 2017
} 
media sector in Afghanistan is the legal framework and the guarantees contained in it. The mass media law of Afghanistan is one of the best laws in comparison to neighboring countries and other countries." 98

The legal guarantees for press freedom in Afghanistan have at least allowed journalists to freely criticize the government. Echoing the war reporter, an Afghan media lawyer with extensive experience in media legislation and advocacy in the country characterized the legal guarantees in a rhetorical way thus: "In practice, it depends what do you define as freedom of the press. If freedom of the press is about criticising the government, then yes there is freedom of the press. Even in Kabul, journalists are not afraid to criticize the government. So, relatively speaking, freedom of expression and press freedom are there in practice. ${ }^{.99}$

However, the biggest criticism in the context of the legal framework for press freedom in Afghanistan, echoed by several research participants, was lack of proper and full implementation of the laws and regulations. In other words, multiple research participants highlighted the fact that the liberal attitude of the state towards the media is not only in the form of establishing a supportive legal framework for the media but also in its lack of enthusiasm and/or inability to enforce the law.

The head of the journalists protection organization summed up the sentiment this way: "Despite persistent push by media support organizations towards implementation of the

\footnotetext{
${ }^{98}$ Author interview with Editor-in-Chief of a leading daily newspaper in Kabul, 1 May 2017

${ }^{99}$ Author interview with Afghan media lawyer and press freedom advocate based in Kabul, 7 May 2017
} 
media laws and regulations, the government has failed to properly implement the law in its entirety."

The editor-in-chief of the Kabul-based daily ascribed the haphazard implementation of the law to the fledgling state of Afghanistan's independent media: "Given the fact that freedom of speech and freedom of the press are new concepts in Afghanistan -- a society in transition -- the sufficient grounds for the full implementation of these laws are not there yet." 100

Another research participant put the challenge this way: "The biggest challenge to freedom of expression, or what leads to limitation of this freedom in practical terms, is lack of enough protection that has to be provided by the government. Law cannot rule on its own, it has to be protected, applied, and enforced." 101

\subsubsection{The right to information is guaranteed in law and respected in practice}

The constitution provides for a right to information from government departments except in cases where this right can "harm the rights of others or public security." 102 The 2005 media law later expanded this definition: "Every individual has the right to request and receive information. The government shall, based on request from the country's citizens, provide the requested information except in cases where the requested information is

\footnotetext{
100 Ibid

${ }^{101}$ Author interview with head of private TV channel based in Kabul, 18 May 2017

${ }^{102}$ Constitution of the Islamic Republic of Afghanistan, Article 50, paragraph 3, Ministry of Justice, Kabul, 2004, Page 14
} 
confidential and its disclosure could jeopardize the country's national interests and territorial integrity or cause harm to the rights of others." ${ }^{, 103}$

A key purpose of the enactment of the law as offered in its article 2 is to "ensure transparency and accountability regarding the actions of government departments." The law provides for a right to information and obligates the government to procure information to those who request it and the general public (article 4). The law also establishes three types of deadlines for government departments to respond to requests for information, ranging from a maximum of ten days and extendable for another three days if there are "justifiable reasons" in cases of general information requests to three days in cases of information requests from the media and 24 hours in cases of personal information requests that concern "the protection of the lives or liberty of individuals" (article 6). The law also obligates government departments to establish access to information focal points with publically accessible contact details (article 10) and provides for a complaints mechanism in cases where unsatisfactory information is provided (article 13). The law also provides a list of the following 8 "prohibitions" where the sharing of information is not allowed including information that may endanger the country's independence, sovereignty, territorial integrity, national security and national interests, may cause the severing of the country's political, economic or cultural ties with other countries, may endanger the life, property or dignity and reputation of an individual, may obstruct a criminal investigation, may prejudice a fair trial, may invade personal privacy and in cases where the information is related to personal business activities

\footnotetext{
${ }^{103}$ Mass Media Law of the Islamic Republic of Afghanistan, Ministry of Justice, 2005, article 5, page 9, http://moj.gov.af/content/files/OfficialGazette/0801/OG_0871.pdf, (Retrieved 15 July 2017)
} 
(article 15). However, a competent court can order the release of personal and business information.

An Afghan journalist with more than a decade of experience writing for domestic and international media outlets such as the New York Times called the enactment of the access to information law "the biggest recent achievement" in the field of media development in the country. "Legally, by having a law for access to information, that is a big achievement," the research participant said. "We're on the right path to put media into a kind of legal framework which will be for the benefit of media organizations and the Afghan people." 104

Most research participants agreed the passage of the access to information law was a substantial step forward for Afghan media in and of itself. However, there was also consensus that lack of implementation of the access to information law was an even bigger issue than in the case of the mass media law.

A media lawyer and press freedom advocate who was part of the independent press organizations' effort to pass the legislation put the lack of implementation of the access to information law down to its novelty and a general lack of a culture of sharing information by the government:

${ }^{104}$ Author interview with Afghan reporter in Kabul, 30 April 2017 
"Right to information is very new in Afghanistan. We recently adopted the right to information law, but still we don't have the culture to provide information. The government believes information is their personal property and don't provide it. It takes days and months for journalists to get information. Information isn't just interview, which can be done easily. But if I go to the Ministry of Higher Education, for example, and ask for their annual budget and get the details of how much they've spent on higher education, they don't provide this information. Also, the government doesn't provide contract details on government expenditures." 105

The head of a major media advocacy organization based in Kabul who had also directly contributed to the effort to secure the passage of the law was disappointed with the slow pace of implementation, especially with regards to the work of the access to information commission. "The commission has not been able to establish its representation in the provinces to secure full cooperation of government entities in the implementation of the law. There are still pervasive challenges with regards to accessing information in Afghanistan."106

However, the media lawyer said the National Access to Information Commission, set up in Kabul in late 2015, is making an effort to implement the law. "The commission is new. It's trying to train government officials to tell them that information isn't their personal

\footnotetext{
105 Author interview with Afghan media lawyer and press freedom advocate based in Kabul, 7 May 2017

${ }^{106}$ Author interview, 8 July 2017
} 
property but belongs to the public, and that it's their job to provide information to anyone who requests it based on the law."107

According to the Afghan media lawyer, the only limitation of the access to information law is that it does not allow foreign citizens working in Afghanistan, including foreign journalists, to directly file information requests. However, this is a limitation that can easily be circumvented as virtually all international media outlets in Afghanistan reply upon Afghan journalists and other support staff for their reporting.

\subsubsection{Editorial independence is guaranteed in law and respected in practice}

Article four of the Mass Media Law (2009) clearly guarantees editorial independence. In addition to guaranteeing "freedom of thought and expression," the article, consisting of two detailed paragraphs, also guarantees the "requesting, receiving and transmitting of information and views within the bounds of the law without any interference, causing of limitation or threat by officials of the government" and provides that "no natural or legal person, including the government and government departments, can prohibit, boycott, censor or limit the free operation of the mass news and information media or otherwise interfere in the affairs of the mass news and information media in any other way."108

\footnotetext{
${ }^{107}$ Ibid

${ }^{108}$ Mass Media Law of the Islamic Republic of Afghanistan, Ministry of Justice, 2009, Article 4, pages 8-9, http://moj.gov.af/content/files/OfficialGazette/0901/OG_0986.pdf, (Retrieved 15 July 2017)
} 
All research participants agreed that the editorial guarantee offered in the law is respected by the government, and practiced by the Afghan media, with some variations between urban and rural areas.

The head of one of the two or three largest national media watchdog organizations said there was "no interference on the part of the government to control or dictate the agenda of media outlets." 109

A veteran Afghan reporter stated that although the government was always careful not to appear to be muzzling independent media outlets directly, "the government does use influence to stop and avoid critical editorials." ${ }^{110}$

At the same time, when discussing editorial independence, nearly all research participants differentiated among media outlets controlled by the government, owned by political parties and powerful individuals, or those private media outlets seen as independent of both government control or any political party affiliation.

Reflecting this shared view, for instance, the head of one of the largest daily newspapers in the country said the government respected editorial independence in the sense that there was no attempt at censorship or any pressure on media outlets to follow a certain line in their editorial views. However, he viewed editorial independence differently

\footnotetext{
${ }^{109}$ Author interview, 8 July 2017

${ }^{110}$ Author interview with Afghan reporter in Kabul, 30 April 2017
} 
depending on whether a media outlet is state-owned, private or affiliated with political entities:

"Government media outlets work in accordance with the policies of the government and function as the propaganda apparatus of the government. The second set of media outlets, which are private outlets, enjoy editorial independence in the context of the mass media law. At the same time, given that there is still no clear definition for private media outlets because many political and ideological media outlets also operate under the umbrella of private media, on occasion these media outlets do not have an independent approach to issues. This legal loophole has allowed for the breach of the media law and nonindependent treatment of issues. This means that we have not yet reached complete editorial independence in the media sector." $" 111$

As noted earlier, there exists a divide between media outlets in the major urban areas that enjoy greater independence versus media outlets in the provinces where journalists are exposed to far greater pressures and problems. As the head of a TV channel based in Kabul put it:

"Editorial independence is more than guaranteed by law but it's not always respected and protected. The situation is much better in Kabul and a few provinces, but in the more remote areas of Afghanistan, it's hard to challenge local authorities and pose fundamental

\footnotetext{
${ }^{111}$ Author interview with Editor-in-Chief of a leading daily newspaper in Kabul, 2 May 2017
} 
questions that undermine the authority of local officials, warlords, and traditionally influential figures."

\subsubsection{Journalists' right to protect their sources is guaranteed in law and respected} in practice

The Mass Media Law guarantees the right of journalists to protect their sources except in cases where a competent court issues an order for the revelation of a source during the prosecution of a case. ${ }^{113}$ All research participants agreed this right was well-protected. The Afghan media lawyer noted that there has only ever been one case where a journalist had to reveal his source after a court order. The major reason for this, the media lawyer pointed out, was the difficulty on the part of the government in obtaining a court order and that the court system, at least so far, has mainly sided with journalists:

"First the government has to go to the media complaints commission. The commission will talk to the journalist if he/she is willing to disclose the source. Then the government can go to the court. Then the court will decide, and the court in most cases will not force journalists to disclose their sources unless the issue is absolutely critical to national security. So this is a very good protection." 114

As another research participant pointed out, the biggest problem with regards to the protection of sources was that younger, less experienced journalists in some cases readily

\footnotetext{
${ }^{112}$ Author interview with head of private TV channel in Kabul, 18 May 2017

${ }^{113}$ Mass Media Law of the Islamic Republic of Afghanistan, Ministry of Justice, 2009, Article 6, page 10, http://moj.gov.af/content/files/OfficialGazette/0901/OG_0986.pdf, (Retrieved 15 July 2017)

${ }^{114}$ Author interview with Afghan media lawyer and press freedom advocate based in Kabul, 7 May 2017
} 
reveal their sources either to the police or a prosecutor often prematurely because they don't know the law or they feel intimidated by government authorities. For example, the newspaper editor-in-chief said: "Professional media outlets follow this rule but nonprofessional media reveal their sources in the initial phase when a case is being looked at by the Media Complaints Commission or the Attorney General's Office, which is against the law."115

Afghan journalists have shown remarkable courage to expose corruption and incompetence within the state structure in the face of significant risks, including in terms of protecting their sources, which are often officials within government agencies. As one research participant put it:

"Journalists are always exposed to intimidation by powerful people, whose influence permeate through the entire state structure. Yet, journalists have in many instances taken risk to expose corrupt officials using sources within the state structure and have done their utmost to protect their sources. There are numerous examples of investigative reports by various media especially those based in Kabul."116

\subsubsection{The public and civil society organisations (CSOs) participate in shaping}

\section{public policy towards the media}

Afghan civil society organizations, particularly independent media associations and prominent individual journalists, have played a key role in developing public policy

\footnotetext{
115 Author interview with Editor-in-Chief of a leading daily newspaper in Kabul, 2 May 2017

${ }^{116}$ Author interview with head of private TV channel based in Kabul, 18 May 2017
} 
toward the media in Afghanistan, especially since the fall of the Taliban regime. For example, according to multiple research participants, independent media organizations came together to support and push the passing of the current mass media law and access to information law. At the same time, these organizations have also played a prominent role in defending journalists and lobbying with the government to institute media-friendly rules and regulations. ${ }^{117}$ As the Afghan media lawyer put it, media support organizations and several individual activists worked alongside sympathetic members of the Afghan parliament "to amend the media law and also the right to information law."

"The general public and also the civil society have been good supporters of the media. They've helped media to grow. Even during the media law working group which journalists were working to amend the media law and also for the right to information law, the civil society were involved and they were supporting and providing different recommendations and input to strengthen the law. Overall, CSOs have played a good role." $" 118$

The editor-in-chief of the Afghan daily, who has actively participated in advocacy for greater press freedom, including with the Afghan parliament, ascribed much of the progress in the field of media development to the dogged efforts of independent media organizations:

\footnotetext{
${ }^{117}$ Author interviews with several media activists based in Kabul during April and July 2017

${ }^{118}$ Author interview with Afghan media lawyer and press freedom advocate based in Kabul, 7 May 2017
} 
"The access to information law was prepared during a six-year period by civil society institutions and media unions and associations until it finally reached the government and was enacted through the legal channels. It is because of this reason that these two laws have created the conditions of journalistic work in favour of the media.",119

A prominent Afghan journalist who has been personally involved in media advocacy for nearly 20 years, said the role of civil society organizations in passing critical pieces of legislation and ensuring their implementation has been critical:

"In fact, civil society was instrumental in drafting different versions of the media law and access to information law. I was personally involved in different committees to revise the media law. Nine years ago, I was part of the Civil Society and Human Rights Network (CSHRN), which launched for the first time the national debate on access to information law. We travelled to different provinces to launch symposiums on what access to information law was and why it was vital to be adopted sooner than later. In fact, media and civil society have been inseparable in their joint efforts to preserve and promote freedom of expression and free media." ${ }^{, 120}$

There are currently more than a dozen independent media support and advocacy organizations in Afghanistan including the following: NAI Supporting Open Media in Afghanistan, Afghanistan Journalists Safety Committee, Media Watch Afghanistan, All-

\footnotetext{
119 Author interview with Editor-in-Chief of a leading daily newspaper in Kabul, 2 May 2017

${ }^{120}$ Author interview with head of private TV channel and member of Afghanistan Journalists and Media Federation, 18 May 2017
} 
Afghanistan Journalists Union, Lawyers Committee Supporting Afghan Media, Internews, Mediothek Afghanistan, Afghanistan Journalists Centre, Afghanistan National Journalists Union, South Asian Free Media Association, South Asian Women in Media, Afghan Women Journalists Union, Afghanistan Independent Journalists Association, Centre for Protection of Afghan Journalists, Kabul Press Club, Afghanistan Independent Radio Association, Afghanistan Independent TV Association, Afghanistan National Journalists and Reporters Union. Most of these organizations are based in the capital, Kabul, but many, such as the Afghanistan Journalists Safety Committee, also have branch offices in the country's other major cities including the four key regional hubs of Kandahar in the south, Herat in the west, Balkh in the north and Nangarhar in the east.

Although the large number of media institutions means there will always be voices in support of the media and it will be difficult to clamp down on all of them at the same time, over the years this dispersal sometimes meant the media sector as a whole was not able to more effectively lobby as a collective for major changes to the media law or get new laws and regulations passed. In order to change this, almost all the major abovementioned institutions came together in January 2013 and launched the Afghanistan Journalists and Media Entities Federation, an umbrella body. ${ }^{121}$ In the judgement of almost all the Afghan research participants, the federation has been able to provide a vast, common and powerful platform for the country's heretofore large but diffuse media community to engage with the government more effectively and stand up for the rights

\footnotetext{
${ }^{121}$ Afghanistan journalists federation is established, Afghanistan Journalists Centre, 20 January 2013 , http://www.afjc.af/index.php/newsmedia/centeral/kabul/532-1391-11-02-05-03-15.html (Retrieved 5 July 2017)
} 
and freedoms of Afghan journalists and the protection of the media sector as a whole, both against abuse by individuals associated with the government or the Taliban. ${ }^{122} \mathrm{~A}$ research participant described the thinking that went behind the formation of the federation in this regard:

"If there is a Taliban attack against a media outlet and just one association stands against this attack, then the Taliban can single out that association. But if the Federation takes the same position, then it will be difficult to target all associations. It's the same in terms of standing up to pressure from the government.",123

According to the media lawyer based in Kabul, the Federation has also taken other notable steps such as the adoption of a code of conduct to improve professional standards among journalists and enhance the credibility of the mass media in the public's eye.

\subsection{Regulatory system for broadcasting}

\subsubsection{Independence of the regulatory system is guaranteed by law and respected in} practice

The media regulatory system in Afghanistan falls under the Mass Media Commission, a legally independent institution whose seven members are supposed to be elected for three-year (four member) and two-year (three members) terms from among "professional individuals with higher education and journalism experience and with consideration

\footnotetext{
${ }^{122}$ Author interviews with several Afghan journalists and media activists in Afghanistan between April and July 2017.

${ }^{123}$ Author interview with Afghan media lawyer based in Kabul, 7 May 2017
} 
given to ethnic and gender balance." 124 The work that the Mass Media Commission overseas falls under the mandate of two separate government ministries, namely the Ministry of Information and Culture, which also pays the budget for the work of the Commission, and the Ministry of Communications and Information Technology, with the former responsible for registering and issuing operating permits to all media outlets and the latter controlling the allocation of radio and TV frequency and spectrum as well as online bandwidth. $^{125}$

In addition to making it easy to register any type of media outlet in Afghanistan, this lax and loose regulatory system also meant that a number of savvy actors bought up most available frequencies available for TV and radio broadcasting in the early years after the fall of the Taliban in 2001. As the editor-in-chief of a major Afghan daily newspaper put it, this created an unexpected challenge in that people who have launched radio or TV channels in recent years "are forced to purchase frequencies on the open market from individuals who bought the rights to these frequencies years ago and still control them." 126

\subsubsection{Regulatory system works to ensure media pluralism and freedom of expression}

\section{and information}

The regulatory system described above makes it seem like it is an elaborate system of regulation spread over one independent and at least two different government institutions,

\footnotetext{
${ }^{124}$ Mass Media Law of the Islamic Republic of Afghanistan, Ministry of Justice, 2009, Article 42, page 34, http://moj.gov.af/content/files/OfficialGazette/0901/OG_0986.pdf, (Retrieved 15 July 2017)

${ }^{125}$ Mass Media Law of the Islamic Republic of Afghanistan, Ministry of Justice, 2009, Articles 32 and 34, pages 26 and 35, http://moj.gov.af/content/files/OfficialGazette/0901/OG_0986.pdf, (Retrieved 15 July 2017)

${ }^{126}$ Author interview with Editor-in-Chief of a leading daily newspaper in Kabul, 2 May 2017
} 
which in theory might provide for a strict regulatory regime. The reality, however, is rather different, with a highly permissive regulatory environment governing - or, more accurately, not governing - a loose and open regulatory system. Some Afghan journalists are happy with this state of affairs. For instance, reflecting the views of many within the media community, the head of a media support organization said, "the Mass Media Council is not fully functional" and that "this makes the regulatory system for broadcasting extremely liberal.",127

However, given the existing complicated and divided nature of the regulatory system and with a long-term view to ensuring its independence, one research participant underlined the need for the government to support the establishment of an independent body outside the framework of the government that would bring together the divided functions and authorities of the two ministries under one roof. Although the research participant said this was "not an easy job," he argued that such a move was necessary to be "better coordinated and more efficient." 128

\subsection{Defamation Laws and other legal restrictions on Journalists}

\subsubsection{The state does not place unwarranted legal restrictions on the media}

The only legal restrictions imposed on the media are contained in article 39 of the Mass Media Law (discussed in pages 2-3).

\footnotetext{
${ }^{127}$ Author interview with head of an independent Afghan media support organization based in Kabul, 8 July 2017

${ }^{128}$ Author interview with Afghan media lawyer based in Kabul, 7 May 2017
} 


\subsubsection{Defamation laws impose the narrowest restrictions necessary to protect the}

reputation of individuals

Afghanistan does not yet have a specific defamation law. The media law, in its article 39, prohibits the publication of anything that causes "defamation to individuals." 129

When it came to the imposition of restrictions writ large - whether in the laws or the regulations that flow from them - research participants were in agreement that the government did not impose any unwarranted curbs on the media.

For instance, the head of a journalists' safety organization which is known for its regular head-butting with government institutions, including the security ministries, had this to say on the topic:

"There are no restrictions imposed on journalists by the state. The state's policies and attitude is extremely liberal towards the media despite the ongoing war and violence. The state is not imposing unwarranted legal restrictions on the media." ${ }^{130}$ On the contrary, he said, "the ultra-liberal attitude of the government towards the media gets criticized sometimes even by the media workers."

Another research participant said restrictions against the media in Afghanistan mostly came from outside the law. "Most restrictions and challenges come in the form of threats

\footnotetext{
${ }^{129}$ Media Law of the Interim Administration of Afghanistan, Articles 39, Ministry of Justice, Kabul, 24 January 2002, http://moj.gov.af/content/files/OfficialGazette/0701/OG_0800.pdf (Retrieved 15 July 2017), page 24

${ }^{130}$ Author interview with head of journalists safety organization based in Kabul, 8 July 2017
} 
and intimidation - not much of a legal restriction. In fact, if journalists and media were able to exercise all of the rights they are currently granted by the law, there would be little left to criticize."131

Another research participant, a veteran war reporter, put the issue thus:

"Let's be honest that, again, the pace of development in the media in Afghanistan is so fast and the pace of regulatory obstacles from the government is slow. Despite that, journalists are under pressure because it's a country of everyday developments, a country of everyday politics and political activities and a lot of fighting. So that's why the pressures on the journalists aren't based in the regulatory basis but it's a kind of pressure outside the law and regulations that happen to them. We're moving very fast on media development and creating media outlets, using social media, using internet-based media but regulation from the government is slow because of its capacity. So not in terms of regulations, but outside the law journalists are under pressure." 132

\subsection{Censorship}

\subsubsection{The media are not subject to prior censorship as a matter of both law and} practice

The Afghan Mass Media Law (article 4) makes censorship an illegal act. The article states that no one, "including the state and state institutions can prohibit, boycott, censor

\footnotetext{
${ }^{131}$ Author interview with head of private TV channel based in Kabul, 18 May 2017

132 Author interview with research participant based in Kabul, 30 April 2017
} 
or limit the free operation of news and information media or interfere in the affairs of mass media in any other way." 133

However, as highlighted by several research participants, the existence of numerous pressures and threats outside the bounds of the legal framework means that many Afghan journalists, in order to ensure their own protection and safety, avoid many sensitive issues and resort to self-censorship.

As one research participant put it:

"There is more self-censorship than censorship by the government. This is more because of the security situation. Journalists and the public can't talk about religious issues, and this is also self-censorship and they can't talk about sensitive issues. But security is the main reason, especially in the provinces where if a journalist wants to talk about local commanders or influential people, he/she can be killed or they'll be forced to flee their place of work." This research participant gave the example of an Afghan reporter for BBC Pashto, killed in Helmand province in 2008, who was working on an investigative report on the opium trade in the province in which most suspected several government officials, including senior leaders of the provincial government, were allegedly involved.

Another research participant noted the strength of the independent media sector in the country as a deterrent against government attempts to impose any type of official

\footnotetext{
${ }^{133}$ Mass Media Law of the Islamic Republic of Afghanistan, Ministry of Justice, 2009, Article 4, pages 8-9, http://moj.gov.af/content/files/OfficialGazette/0901/OG_0986.pdf, (Retrieved 15 July 2017)
} 
censorship. "The government is not very active in terms of media censorship because media outlets and media unions and associations show aggressive reactions in this area. But because of the presence of powerful and law-breaking elements in society, selfcensorship is a phenomenon that exists in Afghanistan's media." 134

At least two other research participants noted another trend whereby state institutions use incentives and indirect threats to try to make journalists refrain from reporting on government weakness and corruption.

An Afghan media lawyer based in Kabul who provides safety advice to journalists and who helps run a media shelter -- temporary housing for journalists who are forced to flee their areas due to threats and intimidation - said there has been a marked increase in the government's use of incentives to cultivate closer ties with the media sector. The research participant said one of the main objectives of this effort was to reduce the amount of negative reporting about the government's performance. The lawyer argued that given the nascent state of independent media in Afghanistan, such "soft" government actions were akin to censorship:

"Unfortunately, in recent years, since the National Unity Government came to power there is a very soft way of influencing the media and how to make them shut down in a soft way. They are actually making connections and making friends in the media and they're hiring some journalists who were critical about government policies and

\footnotetext{
${ }^{134}$ Author interview with head of independent news daily based in Kabul, 1 May 2017
} 
government corruption and other weaknesses of the government. They hired those journalists into the government and that way they shut down criticism. In my opinion, this is another way of censoring the media's role." ${ }^{\prime 135}$ The most prominent example of this approach is the current deputy presidential spokesperson who for years helped run the country's largest daily newspaper, Hasht e Subh, which is usually critical of the government and which is one of very few major media outlets that conduct investigative reporting into government corruption.

A veteran journalist who has carried out investigative reporting characterized such conduct by government officials as an invisible challenge:

"State censorship is invisible and indirectly coercive. The state has tried to stay away from direct censorship, yet officials at individual capacities have applied direct or indirect threats to intimidate journalists and media outlets. For the same reason, journalists have resorted to self-censorship when they have not been sure of their physical security, and where they have felt a potential threat to their lives. The only direct threat has always come from Taliban and other terrorist groups who have deliberately targeted and killed journalists and media personnel."136

Another research participant also singled out journalists' fear for their personal safety as one of the main reasons why journalists often stay away from reporting on issues that might anger powerful officials:

\footnotetext{
${ }^{135}$ Author interview with Afghan media lawyer based in Kabul, 7 May 2017

${ }^{136}$ Author interview with head of private TV channel based in Kabul, 18 May 2017
} 
"The safety of individuals especially journalists is very important for development of media and for development of freedom of speech and freedom of expression but unfortunately in a country like Afghanistan we don't have that kind of safety which helps the development of freedom of speech. Safety of journalists and survival of journalists make them to do self-censorship, as opposed to state censorship. We can't say there is no state pressure on the journalists but it's more self-censorship because of lack of safety and security."137

Also, given much less protection for journalists outside major cities, there is greater selfcensorship in the provinces and rural areas. This is mainly because in many provinces the presence of both Afghan and international forces is thin while the Taliban exert greater influence.

\subsubsection{The state does not seek to block or filter Internet content deemed sensitive or detrimental}

Internet access and the use of the worldwide web is a relatively new phenomenon in Afghanistan. The contrast between 2001 when the Taliban ruled and today is stark, akin to the difference between a dark night and the dawn of a bright day. In July 2001, the Taliban government officially outlawed the internet, arguing that the regime was against "the broadcast of obscene and immoral material" and that it wanted to create a system of

\footnotetext{
${ }^{137}$ Author interview with Afghan war reporter, 30 April 2017
} 
control for incoming and outgoing information. ${ }^{138}$ This changed dramatically after the fundamentalist regime was toppled in October 2001 with the government removing the ban and launching the country's unique internet domain .af in 2003, which the government characterized as "reclaiming part of our sovereignty" and "planting the country's flag on the internet." 139

According to Afghan government data, the number of internet users in the country went from 100 in 2002 to 2.4 million in 2013 with internet traffic growing from 0.02 Gbps in 2002 to 15 Gbps in $2014 .{ }^{140}$ The number of mobile phone users grew from virtually zero in 2001 to more than 20 million subscribers covering nearly 90 percent of the population. ${ }^{141}$ This prompted the then president, Hamid Karzai, to state that in the field of telecommunications and information technology "Afghanistan achieved the same progress in a few years that other countries have gained in several decades." ${ }^{\prime 42}$

For nearly a decade after the fall of the Taliban, there was no government attempt to restrict access to the internet in Afghanistan. However, in June 2010, the Ministry of Communications and Information Technology instructed the 51 internet service providers (ISPs) licensed by the ministry to block sites deemed immoral, such as those promoting alcohol, gambling and pornography. The Committee to Protect Journalists, which reported the ban, also noted that the government had blocked at least one local news

\footnotetext{
138 Taliban 'outlaw internet', BBC News, 13 July 2001, http://news.bbc.co.uk/1/hi/world/south_asia/1437852.stm, (Accessed 25 July 2017)

${ }_{139}$ Afghans plant flag in cyberspace, BBC News, 10 March 2003, http://news.bbc.co.uk/1/hi/technology/2835799.stm, (Accessed 25 July 2017)
} 
website that had incorrectly reported the death of one of the country's vice presidents. ${ }^{143}$

The website in question, benawa.com, is accessible inside the country once again.

Following the introduction of the new regulation, for a while the government began inspecting internet cafes in Kabul city to ensure compliance with the new rule and imposed small penalties on three internet cafes that did not block access to the banned sites in 2011. ${ }^{144}$ As the CPJ noted in its report, most internet users continue to easily bypass the ban using paid and free circumvention software, including virtual private networks (VPNs).

A more serious episode happened during the 2014 presidential election when both of the two run-off candidates, who went on to form a government of national unity, accused each other of massive voting fraud. One of the candidates rejected the provisional results and threatened to form a parallel government. ${ }^{145}$ Social media, especially Facebook, suddenly became a platform for the venting of accusations and counter-accusations, and a

\footnotetext{
${ }^{140}$ Ministry of Communications and Information Technology, Government of Afghanistan, http://mcit.gov.af/Content/images/Eng\%20-\%20Inbound\%20Internet\%20Traffic_png.png, (Accessed 25 July 2017)

${ }^{141}$ Telecom Statistics end of September 2015, Ministry of Communications and Information Technology, http://mcit.gov.af/en, (Accessed 25 July 2017)

${ }^{142}$ Report of the activities and achievements of the Ministry of Communications and Information Technology 2002-2015, http://mcit.gov.af/Content/files/book\%20of\%20coummnication.pdf, (Retrieved 25 July 2017)

${ }^{143}$ Using new internet filters, Afghanistan blocks news site, Committee to Protect Journalists, 6 October 2010, https://cpj.org/blog/2010/10/using-new-internet-filters-afghanistan-blocks-news.php (Retrieved 25 July 2017)

${ }^{144}$ Afghanistan Telecommunications Regulatory Authority fines telecom and internet companies, Ministry of Communications and Information Technology, Kabul, 26 April 2011, http://mcit.gov.af/en/news/1175, (Accessed 25 July 2017)

${ }^{145}$ Abdullah threatens to withdraw from Afghan political process, Voice of America News, 1 September 2014, https:/www.voanews.com/a/abdullah-threatens-to-pull-out-of-afghan-politicalprocess/2434906.html, (Accessed 28 July 2017)
} 
lot of abuse, between the two electoral camps, threatening to polarize the country along ethnic lines. ${ }^{146}$ Some in the government argued for the blocking of social media, particularly Facebook, as a way to tamp down passions on both sides. For instance, the head of the country's premier intelligence agency, the National Directorate of Security or NDS, in public testimony to the Afghan parliament said that he had proposed the blocking of Facebook to Karzai but that the president had rejected the suggestion "for the sake of preserving freedom of expression." ${ }^{\text {147 }}$ This rejection of imposing a ban on Facebook was partly because the media support organizations, including the umbrella Federation, had rallied strongly against any curbing of the media space and had urged Karzai to reject any such proposal from his government ministries. ${ }^{148}$ A meeting of the country's National Security Council, which had rejected the NDS chief's proposal, called on "all Afghan citizens, especially the youth, not to use Facebook to harm national unity and national stability and to use Facebook in a responsible manner."149

Over the years, but especially since the election of 2014, when it played a significant role, social media has become a powerful platform for political discourse, a major source of information and news and a powerful tool for mass mobilization for Afghans. According to Internet World Stats, out of a population of roughly 30 million, Afghanistan had slightly more than 4 million internet users out of which 2.6 million or more than 50

\footnotetext{
${ }^{146}$ Ethnic game and political disunity, BBC Persian News, Kabul, 27 October 2016, http://www.bbc.com/persian/afghanistan-37786153, (Accessed 28 July 2017)

${ }^{147}$ Rustami, Akbar, Where did Facebook take the elections, Hasht e Subh daily, Kabul, 14 July 2014, http://8am.af/1393/04/23/facebook-election-afghanistan/, (Accessed 28 July 2017)

${ }_{148}$ Author interview with Afghan media lawyer based in Kabul, 7 May 2017

${ }^{149}$ Afghanistan's national security council: Use Facebook responsibly, BBC Persian News, 6 June 2014, http://www.bbc.com/persian/afghanistan/2014/07/140706_k04_facebook_in_afghanistan, (Accessed 28 July 2017)
} 
percent used Facebook. ${ }^{150}$ Research participants unanimously agreed that the remarkable growth in the use of social media both by the government and private citizens is a new phase in the development of the media sector in the country. As one research participant put it, social media "is increasingly becoming an influential platform for shaping public discourse and at times shapes the agenda of the traditional media." $" 151$

\subsection{Conclusion}

This chapter showed that when it comes to a formal legal framework providing guarantees and protections for the media sector, Afghanistan is in as good, if not better, place as virtually all of its neighbours in the wider Heart of Asia region. For a country that has endured 40 years of conflict and where press freedom and freedom of expression were banned as recently as 2001 , this represents a tangible achievement and remarkable progress. The legal protections for journalists include editorial independence, the right to protect sources, absence of official censorship and the right to access information.

On the other hand, the chapter identified few but critical limits on press freedom in the form of topics that are off-limit for journalists such as issues related to religious freedom, public morality, etc. The chapter also highlighted ambiguities in the legal framework, such as related to national security and public order, that could potentially be used by a regime opposed to independent media to clamp down on press freedom.

\footnotetext{
${ }^{150}$ Afghanistan, Internet World Stats, http://www.internetworldstats.com/asia.htm, (Accessed 28 July 2017)

151 Author interview with Afghan journalist based in Kabul, 8 July 2017
} 
At the same time, the findings revealed a disorganized, almost non-existent enforcement mechanism or effort on the part of the government to make sure both that journalists enjoy their rights and fulfill their obligations. The chapter showed that this has allowed for a highly permissive environment where few law-based standards or rules are applied, allowing an almost free-for-all media scene.

It is important to note that it is virtually impossible to remove or water down the constitutional guarantees for freedom of expression and press freedom in Afghanistan, as envisioned in the present Constitution itself. This is because the Constitution codifies that "amending fundamental rights of the people," which include freedom of expression and press freedom "shall be permitted only to improve them." 152 Even in a hypothetical scenario where amendments to fundamental rights would be allowed, the mechanism of amendment written into the Constitution itself makes changes to it exceedingly difficult in the country's present circumstances. For instance, the Afghan parliament, unlike in many other countries, does not have the authority to amend the constitution. In Afghanistan's case, that authority rests solely with a so-called Constitutional Loya Jirga, a novel legal creation on the basis of the country's traditional Loya Jirga or grand assembly. Members of a Constitutional Loya Jirga comprise of the following: all members of both houses of the Afghan parliament and chairmen of the elected 34 provincial and 364 district assemblies. ${ }^{153}$ Given that the country has not been able to hold district assembly elections so far since the ratification of the Constitution in 2004, the convening of a Constitutional Loya Jirga remains as remote as ever.

\footnotetext{
${ }^{152}$ Constitution of the Islamic Republic of Afghanistan, Article 149, Ministry of Justice, Kabul, 2004

${ }^{153}$ Constitution of the Islamic Republic of Afghanistan, Article 110, Ministry of Justice, Kabul, 2004
} 
Finally, the chapter showed the significant role that civil society organizations, led by independent media organizations and associations, have played in the growth and development of the modern independent Afghan media, including the shaping and passing of the Mass Media Law and the Access to Information Law. With this level of engagement and advocacy, one would hope that the legal framework and its safeguards for press freedom in the country would sustain for many years in the long term. 


\section{Chapter: PLURALITY AND DIVERSITY OF MEDIA}

This chapter will review and assess the Afghan news media in light of Category 2 of the UN's Media Development Indicators: Plurality and diversity of media, a level economic playing field and transparency of ownership.

The chapter will offer a picture of the level of diversity prevalent in the current media landscape in Afghanistan both in terms of ownership and content. The chapter will seek to identify government policies and regulations that help create a conducive environment for the establishment and operation of a diverse set of media outlets in the broadcast, radio and print sectors. It will also examine the Afghan government's attitude towards the goal of promoting a diverse, pluralistic media sector. This will be done in part by identifying policies and other official government documents aimed at creating a level playing field and a conducive environment for the operation of private, independent media outlets. This review will take into consideration reporting and assessments by various domestic and international independent media watchdog organizations. In addition, the chapter will attempt to identify the key types and categories of Afghan media outlets and whether or not the spread promotes the ideal of a pluralistic and diverse media. The views of primary research participants for this project will inform the discussion.

\subsection{State takes positive measures to promote pluralist media}

'Pluralism' and the promotion of a 'pluralistic society' are familiar words in the lexicon of Afghan government documents over the past 15 years. For instance, one of the 
government's key development documents, the so-called National Development Strategy, underlines the attainment of a "tolerant, united, and pluralistic nation that honors its Islamic heritage and the deep-seated aspirations toward participation, justice, and equal rights for all" as one of its main three goals. ${ }^{154}$ At least in terms of the legal framework, the government's commitment to promoting pluralistic media is also clear. As noted in the previous chapter, the Mass Media Law of Afghanistan calls for the "promotion and development of mass, free, independent and pluralist media." $" 155$

The government's main strategy paper on "culture, media and the youth" states that the government aims to establish media "that are independent, pluralistic and accessible to women and men throughout the country and the creation of an open and democratic society through this." 156 The same strategy document also states that "media pluralism is a key achievement of the country's new democracy in the post-Taliban era" and adds that the government is committed to introducing a "policy and legal framework" that promotes media pluralism. ${ }^{157}$

In response to a question during a discussion at the Council on Foreign Relations in New York in March 2015, the Afghan president, Mohammad Ashraf Ghani, underlined the important role of media in Afghanistan including its diversity. He said "it is extraordinarily important to take account of the media, its diversity, its freedom, and its

154 Afghanistan National Development Strategy, Ministry of Foreign Affairs, Government of Afghanistan, Kabul, page 2, http://mfa.gov.af/Content/files/Volume\%204\%20ENG.pdf, (Retrieved 24 July 2017) 155 Mass Media Law of the Islamic Republic of Afghanistan, Ministry of Justice, 2009, Article 2, page 2, http://moj.gov.af/content/files/OfficialGazette/0901/OG_0986.pdf, (Retrieved 15 July 2017)

156 Culture, media and youth sector strategy, Ministry of Information and Culture, National Development Strategy of the Government of Afghanistan, Kabul, page 3, http://moic.gov.af/fa/page/1326, (Accessed 24 July 2017)

157 Ibid, page 
engagement. We are a debating people, and we like doing it." He said "the media has made a tremendous difference." He in particular emphasized the role that independent TV channels played in the 2014 presidential elections. "Without television, [it] would have been a completely different world.” Speaking to a Western audience, Ghani delved deeper into the 2014 presidential election which he contested against his main rival Abdullah Abdullah, which is a useful illustration of the Afghan people's diverse choices when it comes to media outlets in today's Afghanistan: "I held town hall meetings, and so did Dr. Abdullah. Every single one of our rallies was broadcast at least on five or six television stations. The simultaneity of participation, very old for you, is really novel for us. Because before that, if you're talking to 1000 people, it remained confined to 1000 people. But when 6 million -8 million people routinely watched these, and the debates were really intense, were watched across [the country]. The net result was that 38 percent of women participated in the election."158

\subsection{State ensures compliance with measures to promote pluralist media}

In February 2016, the government, through the Mass Media Commission, passed a detailed bylaw for the registration and operation of private media outlets. The bylaw states that one of its main goals is to "support the free operation of media outlets and organizations for the purpose of the growth and spread of independent and pluralistic media along with social responsibility and ensuring conditions for their free operation." The bylaw also provides protections for journalists and other media workers including standard contracts, pensions, etc. In addition, the bylaw allows Afghan citizens, political

158 President Ghani's remarks in the Council on Foreign Relations (CFR), Office of the President of the Islamic Republic of Afghanistan, Kabul, 26 March 2015, http://president.gov.af/en/speech/presidentghanis-remarks-in-the-council-on-foreign-relations-cfr/, (accessed 23 July 2017) 
parties, unions of political parties, social organizations, companies and non-government organizations as well as foreign citizens and non-government organizations to establish media outlets in the country. Furthermore, in order for journalists to be able "to defend their rights," they can establish "social organizations and independent unions and associations." 159

There is also acknowledgement of the growth of diversity and pluralism in the Afghan media sector from independent observers. For example, the United Nations Educational, Scientific and Cultural Organization (UNESCO) in a 2011 report on lessons learned from media projects said, "In the last decade a diverse media landscape has emerged, bringing voices and opinions to all corners of Afghanistan." 160

In its annual Freedom in the World report for 2015, Freedom House scored Afghanistan as Not Free, largely due to the controversy and tension surrounding the 2014 presidential election and an increase in violence against journalists. Despite this poor mark, the organization noted that "Afghan media continue to expand and diversify, but media workers face major challenges, including physical attacks and intimidation." It added that, "dozens of private radio stations and several private television channels currently operate, conveying a range of viewpoints and criticism of the government" and that "rapidly expanding use of the internet and mobile telephones has broadened the flow of information, particularly for urban residents, but Taliban attacks on mobile phone

159 Bylaw for the operation of private mass media, Articles 3, 7, 49, Bakhtar News Agency, Ministry of Information and Culture, http://bakhtarnews.com.af/dari/culture/item/1355--مقررة-فعاليت-رسانه_هاى_همخانى خصوصى.html?tmpl=component\&print=1, (accessed 24 July 2017)

160 Culture, Education and Media Projects in Afghanistan: what lessons can be learned, UNESCO, page 9, https://www.unesco.nl/sites/default/files/dossier/lessons_learned_afghanistan_1.pdf?download=1, (accessed 23 July 2017) 
infrastructure hinders communications." With regards to the 2014 elections, the report noted that "the election season was replete with robust coverage via radio, television, newspapers, and the web, and the first-ever televised presidential debate."161

Later, in its 2017 Freedom of the Press report, Freedom House upgraded Afghanistan from Not Free to Partly Free in significant measure because of the fact that "the status change also reflects long-term growth in the diversity of private media in Afghanistan." It said that "Afghanistan is home to a large and diverse array of private media outlets, including more than 170 radio stations, and hundreds of print publications." ${ }^{.162}$

A major study of the Afghan media landscape in 2010 noted that, "as a result of [media] diversity, at least urban Afghans now not only have the choice not to watch/listen to media they see as too biased, but also have many more entertainment programs to choose from and less time to filter out the 'noise' generated by this multiplicity of conflicting voices."163

A 2013 assessment on the security threats facing Afghan journalists conducted by the Copenhagen-based International Media Support, noted that "in the last ten years, a vibrant and increasingly professional media sector has grown almost from nothing. Today

161 Afghanistan, Freedom in the World 2015, http://www.freedomhouse.org/report/freedomworld/2015/afghanistan, (accessed 22 July 2017) 162 Afghanistan profile, Freedom of the Press 2017, Freedom House, https://freedomhouse.org/report/freedom-press/2017/afghanistan, (accessed 22 July 2017) 163 Afghan Media in 2010: A Synthesis Report, Altai Consulting, pages 140, http://www.altaiconsulting.com/wp-content/uploads/2016/03/Afghan-Media-in-2010.pdf, (accessed 8 July 2017) 
the country has hundreds of publications, dozens of TV and radio stations and several news agencies." 164

In May 2016, an editorial in Hasht e Subh, the country's leading private independent newspaper, celebrated the "gift" of the country's "free and pluralistic media." It contrasted this modern "gift" with the fact that at least between 1972 (the toppling of the last Afghan king by his cousin in a coup) and 2002 (the collapse of the Taliban regime), "information and the media were wholesale in the hands of the state. These state media sold the ideologies of various governments to the people. However, now independent media operate in relative freedom in the country which also take care of the public interest and the country's security." It went on to point out the public support that exists for the country's independent media. "The people of Afghanistan also recognize the value of this gift," it said. "The widespread support of the society for media and journalists that can be observed in Afghanistan these days is illustrative of the popularity of the media and the work of the media in Afghanistan." $" 165$

In a commentary published on ToloNews.com in Dari in January 2016, the Swedish ambassador to Afghanistan, whose country is a key donor to the war-torn country, praised the growth and diversity of Afghan media. "Today media are playing a prominent role in strengthening transparency, diversity and pluralism in Afghan society," he said.

164 Journalism in Afghanistan: Current and post-2014 threats and journalists safety mechanisms assessment, International Media Support, October 2013, https://www.mediasupport.org/wpcontent/uploads/2013/12/afghanistan-safety-assessment-sept2013-ims.pdf, (accessed 24 July 2017) 165 A few words apropos the world press (freedom) day, Hasht e Subh, 3 May 2016, http://8am.af/1395/02/14/world-press-freedom-day/, (accessed 23 July 2017) 
“Although there is much work to be done, Afghanistan's achievements in the area of freedom of expression and press freedom in recent years have been unprecedented."166

\subsection{A diverse mix of public, private and community media}

One useful way to map out the diversity of the media sector in the country is to look at the growth of broadcast and print media outlets and their ownership over the past decade and a half.

Numerically, the growth of media in Afghanistan, especially non-state media outlets, has been phenomenal since the fall of the Taliban regime. Under the Taliban, media outlets in the country were limited to the state-run Radio Afghanistan (which was renamed Radio Sharia by the Taliban regime) and its local affiliates in some of the major provinces and a few state-run newspapers. On the other hand, the overall number of TV stations, radio stations and print publications since 2001 has exploded into the hundreds. Based on statistics obtained from the Afghan Ministry of Information and Culture, by the end of 2015 there were at least 76 TV stations (38 in the capital Kabul and 38 in the provinces), 166 radio stations ( 37 in Kabul and 129 in the provinces) and a total of nearly 600 print publications (including 50 newspapers and 237 weekly, 182 monthly/bymonthly/quarterly magazines, 20 annual gazettes and 99 government-run print publications, which cover the whole range of bulletins, weeklies, periodicals and professional journals).

166 Anders Sjoberg, Celebrating the 250th anniversary of the passing of the first press freedom law,

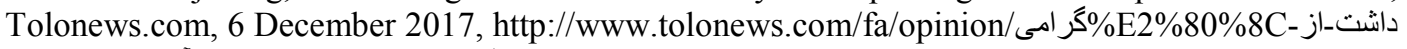
دوصدوينجاهمين-سال-تصويب->(نخستين-قانون-آز ادى-مطبو عات 
In addition to these media outlets, the country boasts 34 registered news agencies. The Afghan government figures on all media outlets provide detailed information on each one, including name, type, ownership (by individuals or organizations), address, telephone number and date of issuance of license for the media outlet. ${ }^{167}$

This unprecedented growth in the number of media outlets available to the Afghan people creates the kind of choice that never existed in the past. It also brings about competition within the media sector over audience shares, which can gradually improve the quality of what the media offer to their audiences.

Most Afghan media outlets produce their content in a mixture of Pashto and Dari, the country's two national official languages, with a small number of broadcast and print outlets catering to the ethnic minority communities in their own languages such as Uzbek, Turkmen, Baluchi, etc. ${ }^{168}$

For instance, RTA, the state-owned broadcaster, provides 80 percent of its content in Pashto and Dari, equally divided between the two languages, with the remaining 20 percent dedicated to minority languages. ${ }^{169}$ In addition to the two national official languages, the country's constitution recognizes six of the country's other languages as official in areas where the speakers of those languages predominate. The constitution

167 Data obtained from Office of Deputy Minister for Administration and Resources, Ministry of Information and Culture, Kabul, 17 November 2015

168 Afghan Media in 2010: A Synthesis Report, Altai Consulting, pages 54, 122, http://www.altaiconsulting.com/wp-content/uploads/2016/03/Afghan-Media-in-2010.pdf, (accessed 8 July 2017)

169 Afghanistan Media in 2014: Understanding the Audience, Altai Consulting, February 2015, page 63, http://www.altaiconsulting.com/wp-content/uploads/2016/05/Altai-Internews-Afghan-Media-in-2014.pdf, (accessed 7 July 2017) 
states that "usage of all current languages in the country shall be free in press publications and mass media." ${ }^{170}$

The number of media outlets that offer content in English partly or fully has also increased in the past decade. Compared to only one English language newspaper in Kabul, the state-owned Kabul Times (founded in 1962), there are now at least 14 newspapers and news agencies that publish either entirely or partly in English. ${ }^{171}$ These include at least two full-fledged private English language dailies published out of Kabul called The Daily Afghanistan and Daily Outlook Afghanistan and a private news agency called Pajhwok Afghan News. ${ }^{172}$ Some TV channels, including the state-owned RTA, also offer short news bulletins in English.

The type of ownership information provided by the government ensures an important level of transparency about media ownership. It also provides useful clues about the editorial orientation and political/ideological bent of each media outlet. For instance, the information shows that Dawat TV is owned by Abdul Rab Rasool Sayyaf, the leader of Etehad-e-Islami, one of the key seven religious armed factions during the decade-long Afghan jehad against the Soviet Union in the 1980s. This information makes it easy to know that Dawat TV is a conservative media outlet which promotes the role of mujahideen in Afghan politics and offers extensive Islamic religious programming in line with the Hannafi school of Islamic jurisprudence.

170 Constitution of the Islamic Republic of Afghanistan, Article 16, Ministry of Justice, Kabul, 2004, Page 4

171 English newspapers, Afghanistan, Newstornado, http://www.newstornado.com/map/, (accessed 25 July 2017)

172 Afghanistan profile - media, BBC News, 18 April 2017, http://www.bbc.com/news/world-south-asia12013942, (accessed 23 July 2017) 
Another example is that of Tamadon TV, which is owned by Sheikh Asef Mohseni, another conservative jehadi leader and religious cleric of the Shia school of Islamic jurisprudence. As a result, his TV channel offers Islamic religious programming in line with the Jafari/Shia school of Islamic jurisprudence.

A further example is Mitra TV, owned by Ata Mohammd Nur, was was governor of the major northern Balkh province for more than a decade until he was replaced in early 2018. Ata is a former Tajik jehadi commander and executive president of Jamiat-e-Islami, one of the largest Islamic/jehadi political parties in the country. Yet another example is Zhwandon TV, owned by Mohammad Ismail Yoon, a prominent Pashtun political activist. Knowing this about these two channels, it becomes fairly straightforward for viewers to be aware of the editorial orientations of both channels, including on issues of ethnicity and language.

Other examples, demonstrating the diversity of TV channels alone, include Taleem-waTarbya (Education) TV run by the Ministry of Education, Ariana Television Network owned by one of the largest mobile phone companies in the country, Tolo TV, perhaps the most popular and influential private TV station in the country, owned by the Mohseni brothers, Afghan-Australians who have made it in the private sector in the post-Taliban Afghanistan, and 1TV, another leading TV channel, owned by Mohammad Fahim Hashimi, another young entrepreneur who has made a fortune in the past decade, including from contracting deals with the U.S. military and other international forces in Afghanistan. 
Although impossible to verify for the purposes of this project, it can be fairly reasonably assumed that not all of the media outlets listed by the Ministry of Information and Culture are active and still in operation. Nevertheless, these sheer numbers on their own demonstrate a sudden and significant flowering of the media scene. The severely restricted environment under the Taliban regime has, over a period of a decade and a half, given way to a situation where pretty much every conceivable state and non-state institution, civil society organization, political party, religious group, social organization and business group and others own and are running their own media outlets.

A prominent journalist and media activist, with long years of experience in promoting journalists' safety, was representative of the positive consensus about the numerical growth in the media sector. "Afghanistan might have the highest number of media outlets per capita in the world," he said. "There is a diverse mix of public, private and community media present in Afghanistan." The research participant added that the country's media landscape represents "various ethnic groups, political groups, and languages. There are also regional and provincial media outlets which mainly cover issues related to the specific region or the province. At the same time, because of the high number of media outlets, there are sufficient news channels, entertainment stations, music, religious TVs, children's television, and women's television."

However, he underlined the government's failure to provide leadership and support in this area. He bluntly stated that "the state does not support pluralism in the media." He 
added, by way of making a distinction, that when it came to the media sector it was the country's constitution that acted as "a strong guarantor of pluralism."173

The editor-in-chief of a leading newspaper in Kabul said "the media sector in Afghanistan in terms of content is not very diverse at the moment but in terms of types of media, it is diverse." He gave the following example: "Most media outlets focus on political and current affairs issues. The space for professional media in niche areas is still empty. Although there are some TV and radio channels exclusively focusing on music, films or sports, this process is not a general trend and this trend has not spread to other areas. In other words, we don't have professional media outlets focusing on particular topics."

The research participant added that the media sector growth had not progressed in a balanced manner. For example, "print publications have not managed to break into the rural areas and villages and urban radio stations have not been able to establish themselves as primary media outlets." He argued that this "unusual progress has resulted in a varied level of understanding of the media sector by the public. In other words, in general terms, the understanding of a villager about the media is linked to radio and that of a city dweller to TV."

Lamenting the passive attitude of the government in promoting diversity and pluralism in the media sector, the editor-in-chief said "the government has not even been able to make its own media outlets available widely." He said that in addition to the legal guarantees

\footnotetext{
${ }^{173}$ Author interview with research participant based in Kabul, 8 July 2017
} 
for media diversity and pluralism, "the only factor that has created media pluralism is a commercial perspective towards the media as a private institution." 174

Another veteran journalist who has worked in print, radio and TV journalism in Afghanistan since 2001 said "media has never been as diverse as it is today in Afghanistan." The hundreds of media outlets "represent different languages, tastes, cultures as well as political and cultural agendas," he said. "While many of them pursue conflicting agendas, nevertheless they provide a medium for plurality of views and reflecting the realities of Afghanistan society."

In terms of government support, this research participant said "the state has been supportive in general." However, he immediately contrasted that with the negative attitude of many senior government officials toward non-state independent media. He gave the example of a former culture and information minister who in 2008 had labelled "freedom of expression" as "a nonsense matter."175

Another research participant referred to ideological diversity among media outlets. "We have media outlets with a past of communist ideology and we do have media which follow more of a kind of Islamist ideology. We also do have media which are in the hands of different political parties. It's a very diverse media sector."

At the same time, this research participant also bemoaned the government's support for the promotion of diversity and pluralism in the media sector was mostly "on paper." "If you're talking about the current government, in their slogans and words, they believe in

\footnotetext{
${ }^{174}$ Author interview with research participant based in Kabul, 1 May 2017

${ }^{175}$ Author interview with research participant in Kabul, 18 May 2017
} 
media pluralism," he said. "But in other instances, it restricts media outlets" or tolerates attempts at restriction by other powerful figures.

In this connection, the journalist mentioned the case of the Afghan government's peace agreement with a notorious militant leader, Gulbuddin Hekmatyar, in $2016^{176}$. According to the journalist, the peace agreement resulted in a situation where "as soon as [Hekmatyar] came to Kabul, he did put pressure on the media." The research participant attributed this to the weakness of the government which in the future may be forced to offer concessions or, at the very least, turn a blind eye to such attacks against the media "to appease certain political groups.",177

Illustrating the media community's concern, Hekmatyar, in a public address in April 2017 shortly after his return to Kabul, launched a verbal broadside against the country's independent media. He called the media "accursed" and accused them all of "sowing discord among the different ethnic groups of the country" and "giving the enemy their fighting morale." He said, "I call on all the people to come and shut the mouths of these troublemaker media outlets. ${ }^{, 178}$

It is important to note that this unprecedented, wholesale assault triggered an equally vocal response from journalists, media support organizations and even the Ministry of Information and Culture. All of these actors took a firm stand in defence of press freedom

\footnotetext{
${ }^{176}$ Afghanistan: Hezb-i-Islami armed group signs peace deal, Al Jazeera.com, 22 September 2016, https:/www.theguardian.com/world/2017/may/04/afghan-warlord-gulbuddin-hekmatyar-returns-kabul-20years-call-peace (Accessed 20 September 2017)

${ }^{177}$ Author interview with research participant in Kabul, 30 April 2017

${ }^{178}$ Anisa Shahid, Hekmatyar's second attack against the media after his appearance in public, Tolo News,

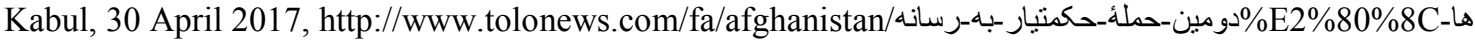
يس-از -ظاهر -شدن-در -انظار _عمومى, (accessed 20 July 2017)
} 
in the country. They variously termed Hekmatyar's assault as “against the country's constitution," "unIslamic," and even against the very peace agreement Hekmatyar had signed with the government, which included respect for Afghanistan's constitution and laws. $^{179}$

In the days after Hekmatyar's extraordinary assault on the media, the deputy minister of information and culture added the government's voice to those of the journalists and press freedom organizations. He said that "malicious and dark words about press freedom will have no effect" and that "no government official, party, group or movement can limit the free activities of the media." 180

A 2012 independent study commissioned by the Center for International Media Assistance and the National Endowment for Democracy noted that ten years after the fall of the Taliban regime, "the media scene in Afghanistan is a lively place." It said, "Afghanistan's main cities are close to media saturation." The study went on to say that, "As might be expected with such a new and varied industry, the quality of content ranges from good to poor.",181

The low quality of media content is something the Afghan government has also complained about. For example, in July 2016, the country’s deputy minister of

\footnotetext{
${ }^{179}$ Nabila Ashrafi, Nai reaction to Hekmatyar's statements about the media, Tolo News, Kabul, 1 May 2017, http://www.tolonews.com/fa/afghanistan/هاى-حكمتيار -در -بار ه-80\% رسانه

${ }^{180}$ Ministry of Information and Culture reacts strongly to Hekmatyar's statements, Ariana News, Kabul, 30

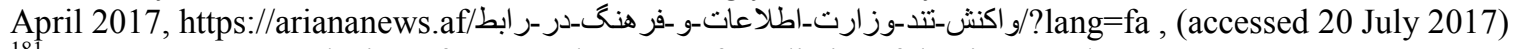
${ }^{181}$ Peter Cray, An Explosion of News: The State of Media in Afghanistan, February 2012, https:/www.internews.org/sites/default/files/CIMA-Afghanistan_\%2002-23-12.pdf, (accessed 20 April 2017)
} 
information and culture said, "the biggest challenge we have in our media law is the question of media content ... and we need to do more in this area." ${ }^{" 182}$

A leading Afghan media lawyer agreed that the numerical growth in the media sector did not extend to diversity of content in media outlets' programming. For example, he said different TV channels based in Kabul "broadcast the same programs under different names. If one TV station has a political show called Ahmad, the other TV station will have a political show called Mahmood, but they'll be the same. There are many media outlets but I don't see a good diversity. There is relative diversity."

The main reason for this lack of content diversity, this research participant contended, was the government's "hands-off approach and not shaping diversity." He argued that in order to promote the type of diversity and pluralism in the Afghan media sector envisaged in the relevant laws, media development policies and regulations should be entrusted to an independent body with professional individuals "who can develop good policies. This is something we are really missing." The current entity tasked with this responsibility is the Media High Council. The research participant said the council is still run by “weak people who don't have much knowledge or experience about the importance of media or know the media landscape." 183 This critique is especially noteworthy as the council has representation from civil society and media support organizations, with the goal that their voices are heard in the formulation of government policies affecting the operation and development of the media sector.

\footnotetext{
${ }^{182}$ Mohammad Halim Karimi, Media as a principal force in democratic governments have great importance, Pajhwok Afghan News, 17 July 2017, https://www.pajhwok.com/dr/2016/07/17/_سانه_ها-بـ/2017) عنوان_قدرت_بنيادين-در -حكومت_از _اهميت_فر اوان-برخوردار اند (accessed 8 July 2017)

${ }^{183}$ Author interview with Afghan media expert in Kabul, 7 May 2017
} 
A 2014 survey showed that in terms of content, Afghan media was dominated by news, drama, entertainment and political programs. ${ }^{184}$ A week-long review of the evening programs of the top three channels over a period of one week (9-16 September 2017) showed that there has been little change in content in the three years since the above survey was conducted.

At least one research participant, from the eastern province of Ghazni, said it was important to assess diversity within the Afghan media from a professional quality perspective. He said that lack of quality journalism, especially in areas outside Kabul and the major capitals hindered the growth of the quality and diversity of media content. This, he said, resulted in a situation where "often times one cannot hear anything but useless noise" from the media. "It is therefore important that we question these matters. Professional people need to be recruited into media outlets."

The research participant added that because of lack of quality on the part of local media, a lot of people in the countryside "still trust foreign media outlets" for their news. ${ }^{185}$ In this context, by 'foreign media outlets,' this journalist mainly referred to the Pashto and Dari language services of the BBC World Service and Voice of America/Radio Liberty, which the Afghan people have been listening to since the early days of the Afghan national resistance against the 1979 Soviet invasion. ${ }^{186}$

\footnotetext{
${ }^{184}$ Afghan Media in 2014: Understanding the Audience, Altai Consulting, February 2015, http:/www.altaiconsulting.com/wp-content/uploads/2016/05/Altai-Internews-Afghan-Media-in-2014.pdf, (accessed 7 July 2017)

${ }_{185}$ Author interview with Afghan journalist in Ghazni, 7 May 2017

${ }^{186}$ Eran Fraenkel et al, Afghanistan Media Assessment: Opportunities and challenges for peacebuilding, United States Institute of Peace, Washington DC, page 16,
} 
On the other hand, despite limitations in content diversity, some research participants still saw the particular role the various media outlets play in raising awareness among the population about different issues, especially in the countryside, as significant. For example, a reporter from the northern city of Mazar-i-Sharif said the growth of media and its penetration into the countryside has had "a constructive role in illuminating people's minds, especially in the villages, about women's rights, the role of literacy in life, political rights such as voting and participation in elections, agriculture, education, etc. $" 187$

Another reporter, from the eastern province of Nangarhar, said that although there is "good diversity" in the media landscape, this was largely because of "the pressures from media organizations on the government." He said such pressure "should be continued."

However, he said the rapid growth in the number and types of media outlets may not be in the best interests of the country. "Factional, party-affiliated and ethnic media outlets have made the people anxious and confused and this is not in the interest of the society." The research participant acknowledgd that it may be impossible to roll back such media outlets without bringing fundamental changes in the legal framework governing the media sector. However, he said it was important to enhance "the process of transparency" to find out the funding sources of partisan media outlets.

The research participant said the best way to ensure such transparency would be through the establishment of "impartial media support organizations." This, he argued, would

https://www.usip.org/sites/default/files/resources/PW68_Afghanistan_Media_Assessment1.pdf, (accessed ${ }_{18}$ July 2017)

${ }^{187}$ Author interview with Afghan journalist in Mazar-i-Sharif, 8 May 2017 
have the added benefit of protecting the country from the "propagation of foreign cultures and instead help reflect the pains of Afghan society." 188

The diversity of Afghan media is also reflected by the fact that two of the previously most deprived segments of Afghan society - namely women and the disabled - today have multiple media outlets, primarily radio stations, addressed to them.

For example, of the 166 radio stations in Kabul and in the provinces cited above, at least 16 are owned by women, mostly journalists or social activists. These outlets have names such as Voice of Woman, Sunrise, Light, Torch, Rabia Balkhi (a famous historical figure and stateswoman who lived in the $10^{\text {th }}$ Century and who is a popular role model among Afghan women today) and specifically cater to a female audience.

Also, in May 2017, a group of Afghan journalists launched the country's first full-fledged TV channel called Zan (Woman) targeted at a female audience. Of its initial 70 staff members, 48 were women. ${ }^{189}$ Two months later, another group of 50 journalists, mostly women, launched the country's second women's TV channel called Banu (Lady), which also launched an eponymous radio channel. ${ }^{190}$ Although it is too early to say whether these steps will enhance the role of Afghan women in the media sector in the long term, it would be fascinating to follow the evolution of such initiatives that are breaking new ground in Afghanistan's conservative society.

\footnotetext{
${ }^{188}$ Author interview with Afghan journalist in Jalalabad, 8 May 2017

${ }^{189}$ Zan: Afghanistan's First TV dedicated to the women of Afghanistan, The Daily Afghanistan, Kabul, 22 May 2017, http://www.dailyafghanistan.com/national_detail.php?post_id=140046, (accessed 22 July 2017)

${ }^{190}$ F. Makhdoom, Second women TV channel to go on air in Kabul, The Kabul Times, 23 July 2017 , http://thekabultimes.gov.af/index.php/opinions/social/14537-second-women-tv-channel-to-go-on-air-inkabul.html, (accessed 22 July 2017)
} 
In terms of the disabled, the United Nations Development Program and, later, Internews, a US-based NGO supporting the development of Afghanistan's independent media sector, helped establish a special radio program to cater to the special needs of Afghanistan's disabled population of nearly one million. The program was run by a disabled young woman who had lost one of her legs to a landmine, most likely a remnant of the dark period of Soviet invasion of Afghanistan from 1979-1989. ${ }^{191}$

According to Nai Supporting Open Media in Afghanistan, the overall number of Afghan journalists in March 2017 was 12,553 of whom 17 percent or 2,366 were women. The number of female journalists in 2017 showed a notable increase of 12 percent over 2016, which is a very promising sign for the prospects of women's participation and role in the country's media sector. ${ }^{192}$

Based on the findings so far, a survey of the media landscape already outlined shows that in terms of diversity, media outlets in Afghanistan can be divided into the following three broad categories: state-owned, independent, and partisan or party-affiliated.

State-owned media, predictably, serve to promote the government line. The main players in this category are Radio Television Afghanistan (RTA), which has local affiliates in virtually all of Afghanistan's 34 provinces, the state-run Bakhtar News Agency and a handful of government newspapers. With regards to RTA, its claim to fame is the

\footnotetext{
${ }^{191}$ Patricia Chadwick, Amina Azimi - Raising the voices of the disabled in Afghanistan, Internews, 25 March 2016, https://www.internews.org/story/amina-azimi-raising-voices-disabled-afghanistan, (accessed 21 September 2017)

${ }^{192}$ Zahra Nazari, Nai speaks about an increase in the number of women journalists in the media, Pajhwok Afghan News, 20 March 2017, https://www.pajhwok.com/dr/2017/03/20/نى-از -افز ايش-تعداد-خبرنخار ان-زن-در رسانه_ها-خبر_-داد, (accessed 20 July 2017)
} 
channel's main daily evening news bulletin which offers a wall-to-wall coverage of the daily meetings and activities of key government leaders and departments, thus offering an official account of the government's activities both on the domestic and international fronts.

The strict requirement for RTA and other state-owned media outlets to stick to the official line has even caused disaffection within the organizations themselves, including at the highest levels of their management. For instance, in January 2017, the Director General of both RTA and the deputy director of the official Bakhtar News Agency publicly voiced their frustration about interference into their work both from the Afghan presidential palace and parliament. Mary Nabardayeen, the official from Bakhtar, told local media that she lacked independence in her editorial decision making. "Every day our news bulletin is filled with news of killings, news of suicide bombings, news of explosions. We have taken away people's hope in the future with our news." She took a direct jab at the highest levels of government power. "How can I bring change? Give me some independence. When news from the presidential palace arrives to me, I am told not to touch it. Professionally, I have no independence to touch that news."

The head of RTA, in a similar vein, complained that "there is still interference in our professional activities or in matters that we should be deciding. Sometimes officials are upset with us. Interferences into our professional work has slowed down our work.”193

\footnotetext{
${ }^{193}$ Homaira Alokozai, Officials of National Radio Television and Bakhtar News Agency: We don't have professional independence, Azadi Radio, Kabul, 15 January 2017, https://da.azadiradio.com/amp/28234441.html (accessed 19 August 2017)
} 


\begin{tabular}{|l|l|l|l|}
\hline No. & Channel Name & Main language(s) & Audience share \\
\hline
\end{tabular}

There are also a number of government newspapers published in Kabul and in the major provincial capitals that largely publish news from Bakhtar News Agency and generally provide pro-government accounts on the important issues of the day. ${ }^{194}$

Although the vast majority of the broadcast media outlets in operation in Afghanistan today are privately-owned commercial independent stations, there are only a dozen or so channels that dominate the market. The following two tables respectively show the audience share and daily reach of the leading TV channels and radio stations in Afghanistan:

Table $1^{195}$ : Leading $10 \mathrm{TV}$ channels in Afghanistan by percentage of audience share (average of rates in the August 2013 - November 2014 period)

\footnotetext{
${ }^{194}$ Afghan Media in 2010: A Synthesis Report, Altai Consulting, pages 63-64, http://www.altaiconsulting.com/wp-content/uploads/2016/03/Afghan-Media-in-2010.pdf, (accessed 8 July 2017)

195 Adapted from Afghanistan Media in 2014: Understanding the Audience, Altai Consulting, February 2015, page 93, http://www.altaiconsulting.com/wp-content/uploads/2016/05/Altai-Internews-AfghanMedia-in-2014.pdf, (accessed 7 July 2017)
} 


\begin{tabular}{|l|l|l|l|}
\hline 1 & Tolo & Dari and Pashto & 49.8 \\
\hline 2 & Lemar & Pashto & 9.7 \\
\hline 3 & Khorshid & Pashto and Dari & 8.5 \\
\hline 4 & Ariana Television Network & Dari and Pashto & 5.6 \\
\hline 5 & RTA & Pashto and Dari & 2.9 \\
\hline 6 & Tolo News & Dari and Pashto & 2.6 \\
\hline 7 & Shamshad & Pashto and Dari & 2.2 \\
\hline 8 & 1TV & Dari and Pashto & 1.5 \\
\hline 9 & Noor & Dari & 1.3 \\
\hline 10 & Tamadon & Dari & 1.2 \\
\hline
\end{tabular}

Table 2: ${ }^{196}$ Leading 11 radio channels in Afghanistan by percentage of average daily reach (average of rates in the August 2013-November 2014 period)

\begin{tabular}{|l|l|l|l|}
\hline No. & Channel Name & Main language(s) & Audience share \\
\hline 1 & Azadi & Dari and Pashto & 17.4 \\
\hline 2 & Arman FM & Dari & 11.1 \\
\hline 3 & BBC & Pashto and Dari & 6.9 \\
\hline 4 & Arakozia & Pashto & 5.5 \\
\hline 5 & Ashna & Pashto and Dari & 3.5 \\
\hline 6 & Bayan & Dari & 3 \\
\hline 7 & Killid & Dari and Pashto & 2.3 \\
\hline 8 & Ariana & Dari and Pashto & 2.3 \\
\hline 9 & Shamshad & Pashto and Dari & 1.4 \\
\hline 10 & Sanga & Pashto & 1.1 \\
\hline 11 & Kabul & Pashto and Dari & 1 \\
\hline
\end{tabular}

${ }^{196}$ Adapted from Afghanistan Media in 2014: Understanding the Audience, Altai Consulting, February 2015, page 92, http://www.altaiconsulting.com/wp-content/uploads/2016/05/Altai-Internews-AfghanMedia-in-2014.pdf, (accessed 7 July 2017) 
In the above two tables, only RTA and Kabul radio are state-owned channels. This clearly shows that independent media outlets represent the vast majority and most influential segment of the media sector in Afghanistan today, which heavily dominate audience shares.

As noted previously, partisan or party-affiliated media, which are represented by Noor and Tamadon TV channels in Table 1 above (there is no party-affiliated radio represented in Table 2), are owned and operated by powerful individuals or political parties.

A major 2010 study of the Afghan media conducted by an international consulting firm, Altai Consulting, noted that many of these party-affiliated channels might be receiving financial backing from neighbouring countries that aim to exert their political and cultural influence into Afghanistan. And although journalists working for these media outlets may also enjoy a certain degree of freedom in their day-to-day work, "the overall political orientation is obviously in accordance to that of the founder.",197

The study cautioned that many of these partisan media - what it also called "gang media" - presented a threat to the positive diversity in the Afghan media landscape. It said the strong political and ethnic agendas of many if not all of these outlets create "a risk for the political landscape in general, in terms of transforming the media into a platform for political campaigns more than for debate, one for voicing resentment and partisan

\footnotetext{
197 Afghan Media in 2010: Synthesis Report, Altai Consulting, page 56, http://www.altaiconsulting.com/wp-content/uploads/2016/03/Afghan-Media-in-2010.pdf, (accessed 8 July 2017)
} 
opposition rather than diversity and one focusing on clienteles rather than the nation at large."198

No survey has yet been done on audience shares among print media outlets to date. One reason, perhaps the main reason, for this is the low penetration rate and audience preference for print media in general (see Table 4 below). The main reason for the low penetration rate and audience preference for print media is the literacy rate in Afghanistan, one of the lowest in the world. According to the United Nations, the average national literacy rate in the country in 2011 stood at just 32 percent, with a male literacy rate of 45 percent which precipitously drops to a dismal 18 percent for women. ${ }^{199}$

However, based on an observation of various sources, the following table shows the top ten newspapers in the country.

Table $3^{200}$ : Print media audience shares

\begin{tabular}{|l|l|l|l|}
\hline No. & Newspaper & Main language(s) & Circulation \\
\hline 1 & Hasht e Subh & Dari and Pashto & 15000 \\
\hline 2 & Wesa & Pashto & 6000 \\
\hline 3 & Mandegar & Dari & 5000 \\
\hline 4 & Mehwar & Pashto & 4000 \\
\hline 5 & The Afghanistan Daily & English & $\mathrm{n} / \mathrm{a}$ \\
\hline
\end{tabular}

\footnotetext{
${ }^{198}$ Afghan Media in 2010: A Synthesis Report, Altai Consulting, page 167, http://www.altaiconsulting.com/wp-content/uploads/2016/03/Afghan-Media-in-2010.pdf, (accessed 8 July 2017)

${ }^{199}$ Literacy rate among the population aged 15 years and older, United Nations Educational, Scientific and Cultural Organization Institute for Statistics, http://uis.unesco.org/en/country/af, (accessed 23 July 2017)

${ }^{200}$ Kabul newspapers, Pajhwok Afghan News, http://www.elections.pajhwok.com/en/content/kabulnewspapers and Kabul newspapers, Afghanistan Journalists Centre, http://afjc.af/index.php/info/centeral/kabul/2015-07-25-13-11-11.html, (accessed 23 July 2017)
} 


\begin{tabular}{|l|l|l|l|}
\hline 6 & Afghanistan Times & English & n/a \\
\hline 7 & $\begin{array}{l}\text { The Kabul Times (state- } \\
\text { owned) }\end{array}$ & English & n/a \\
\hline 8 & Afghanistan Express & English & n/a \\
\hline 9 & Hewad (state-owned) & Pashto & n/a \\
\hline 10 & Islah (state-owned) & Dari and Pashto & 3500 \\
\hline 11 & Etilaat Roz & Dari & 3000 \\
\hline 12 & Anis (state-owned) & Dari & $2200-2500$ \\
\hline 13 & Sokhan e Jadid & Dari & 2500 \\
\hline 14 & Arman e Milli & Dari & 2000 \\
\hline 15 & Open Society & Dari & 2000 \\
\hline
\end{tabular}

The circulation numbers above are not significant but what is noteworthy is that newspaper readers usually read the paper to others who cannot read and write, including children. $^{201}$

Another more significant factor that increasingly helps newspapers - and, for that matter, other print publications - reach much larger audiences is the fact that most print publications have established their own websites and use social media sites such as Facebook extensively to promote their content. For example, the largest newspaper, Hasht e $\mathrm{Subh}^{202}$, has a Facebook following of 1.7 million users which compares with over 300,000 followers for the $11^{\text {th }}$ ranked Etilaat $\operatorname{Roz}^{203}$ and the much smaller following of

\footnotetext{
201 Afghan Media in 2010: Synthesis Report, Altai Consulting, page 102, http://www.altaiconsulting.com/wp-content/uploads/2016/03/Afghan-Media-in-2010.pdf, (accessed 8 July 2017)

${ }^{202}$ Hasht e Subh Facebook page, https://www.facebook.com/hashtsubhdaily, (accessed 22 July 2017)

${ }^{203}$ Etilaat Roz Facebook page, https://www.facebook.com/dailyetilaatroz, (accessed 22 July 2017)
} 
170,000 for Mandegar ${ }^{204}$, the second largest newspaper by print circulation. Given the above numbers and the fact that the number of internet users went from 100 in 2002 to 2.4 million in 2013, it seems reasonable to assume that most newspaper readers in Afghanistan have moved online. ${ }^{205}$

In terms of audience preferences, until 2010 radio was the dominant medium through which the majority of Afghans got their news and information, followed by TV and print media. However, a clear trend in favour of TV viewership is evident. Table 4 below illustrates audience preferences in 2010 and Table 5 shows comparative TV and radio audience preferences over a four-year period (2013-2016):

Table $4^{206}$ : Percentage of media penetration rates in June 2010

\begin{tabular}{|l|l|}
\hline Media type & Penetration rate \\
\hline Radio & 63 \\
\hline TV & 48 \\
\hline Print & 13 \\
\hline
\end{tabular}

\footnotetext{
${ }^{204}$ Mandegar Facebook page, https://www.facebook.com/mandegardailynews, (accessed 22 July 2017)

${ }^{205}$ Internet users, Ministry of Communications and Information Technology, Kabul, http://mcit.gov.af/Content/images/Eng\%20-\%20Internet\%20Users.png, (accessed 23 July 2017)

${ }^{206}$ Adapted from Afghan Media in 2010: Synthesis Report, Altai Consulting, page 98, http://www.altaiconsulting.com/wp-content/uploads/2016/03/Afghan-Media-in-2010.pdf, (accessed 8 July 2017)
} 
Table $5^{207}$ : Percentage of audience preferences for TV and radio as sources of information in a four-year period (2013-2016)

\begin{tabular}{|l|l|l|l|l|}
\hline $\begin{array}{l}\text { Media } \\
\text { Type } \backslash \text { Year }\end{array}$ & 2013 & 2014 & 2015 & 2016 \\
\hline Radio & 78 & 77 & 76 & 70 \\
\hline TV & 55 & 58 & 62 & 66 \\
\hline
\end{tabular}

It is straightforward to note from the last two tables that television has been steadily gaining ground over radio as the preferred source of news and information over the past years. Given improvements in broadcast technologies and the decision of the Afghan government to digitize all television broadcasting in the future, one could make a fairly firm prediction that TV will soon surpass radio as the most preferred news and information medium in the country. ${ }^{208}$ Digitization will remove frequency limitations on TV broadcasting, and thus solve the challenge of saturation in the TV market.

\subsection{License and spectrum allocation}

The government's 10-year telecommunications and information technology policy framework states that "media plays an important role in mass communication, entertainment, education, public participation and strengthening democracy." It offers three main policy objectives for the period 2015-2024: 1) To "encourage the growth and development of broadcasting and media industry that is efficient, competitive and

\footnotetext{
${ }^{207}$ Adapted from A Survey of the Afghan People: Afghanistan in 2016, The Asia Foundation, Kabul, page 133, https://asiafoundation.org/wp-content/uploads/2016/12/2016_Survey-of-the-Afghan-People_fullsurvey.Apr2017.pdf, (accessed 8 July 2017)

${ }^{208}$ Priorities of MCIT for the next three years, Ministry of Communications and Information Technology, Government of Afghanistan, Kabul, http://mcit.gov.af/en, (accessed 25 September 2017)
} 
responsive to the needs of the people of Afghanistan," 2) To "create an enabling environment to increase investment into broadcasting, increase competition and adoption of modern technologies to provide top rated services at affordable prices, and 3) To "encourage the growth and development of digital social media" with a focus on developing domestic social media platforms in order to "accelerate the growth of responsible social media in the country.,"209

The government's separate telecommunications and internet policy states that “Afghanistan's spectrum policy is intended to maximize benefits for spectrum use by fostering competition, controlling harmful interference and stimulating the deployment of innovative services and technologies." The document goes on to add that "award of radio frequencies will be subject to an open, transparent and competitive tendering process."210

The 2016 bylaw on the operation of private media outlets specifies licensing fees for the establishment of various types of media outlets, which, even by Afghan standards, are affordable. For example, calculating by the exchange rate of \$1 USD to 68.5 Afghanis in September 2017 in Kabul, the licensing cost for establishing a print publication is the equivalent of \$29 USD, for a radio station \$43 USD and for a TV channel \$72 USD, which is the highest licensing fee in the bylaw. Each license is valid for a period of five years at the end of which it can be extended for another five years for half the amount of the original licensing fee or for ten years if the full licensing fee amount is paid. The

\footnotetext{
${ }^{209}$ ICT policy for Afghanistan: A digital agenda for development and social change (2015-2024), Ministry of Communications and Information Technology, Kabul, pages 31-32, http://mcit.gov.af/Content/files/Draft-ICT\%20Policy\%20Document.pdf, (accessed 23 July 2017)

${ }^{210}$ Telecommunications and internet policy, Ministry of Communications, Islamic Transitional Government of Afghanistan, November 2003, page 7, http://mcit.gov.af/Content/files/AfghanistanTelecomPolicy_English29112010235311722.pdf, (accessed 23 July 2017)
} 
bylaw also exempts print publications and media outlets run by non-profit organizations from paying any taxes. ${ }^{211}$ This practically means that virtually any Afghan citizen has an affordable path to establishing their own private, independent media outlet.

However, a research participant pointed out two major flaws in the licensing and spectrum allocation system. As noted previously, operating licensing is handled by the Ministry of Information and Culture whereas spectrum allocation is in the hands of the Ministry of Telecommunications and Inforamtion Technology. The research participant said the first problem is that there is poor coordination between the two departments. The second problem, he said, was patronage and nepotism in spectrum allocation. He described a typical license and spectrum allocation process for setting up a TV station. "What happens is if you want to establish a TV station, you first apply to MOIC and they issue you with a broadcasting license right away. However, when you go to ATRA, which issues the spectrum license they say, 'well, we're sorry there is no spectrum available anymore.' This clearly shows lack of coordination between ATRA and MOIC. Now in Kabul you can't get license for a radio station because all frequencies have been allocated," he said. "Even when spectrum was available in past years, it was not easy to get spectrum allocation unless you were friends with the president or the minister of information and culture." ${ }^{212}$

\footnotetext{
${ }^{211}$ Bylaw for the operation of private mass media, Articles 20, 22, 23, 55, Bakhtar News Agency, Ministry of Information and Culture, http://bakhtarnews.com.af/dari/culture/item/1355--مقررة-فعاليت-رسانه_هاى_همكانى خصوصى.html?tmpl=component\&print=1, (accessed 24 July 2017)

${ }^{212}$ Author interview with Afghan journalist in Kabul, 7 May 2017
} 


\subsection{Taxation and business regulation}

The Mass Media Law mandates taxation on the revenues of media outlets operating in Afghanistan. However, the law exempts all print publications from paying taxes. ${ }^{213}$ However, the country's Ministry of Finance for years used its powers to exact taxes from print publications "in violation of the Mass Media Law despite persistent efforts by print media outlets." 214

To rectify this legal violation belatedly and help create a more economic level playing field in the media sector, including for financially vulnerable print and radio outlets, the Afghan government took a significant step in August 2016. It waived all outstanding tax dues of print and radio media outlets, news agencies and publishing houses, which had been a long-standing demand of the country's media sector. The decision was announced during a meeting of the Afghan president with journalists and media activists. In a statement about the meeting, the government said the decision was made in order to "remove challenges, prevent bankruptcy and support and strengthen print and audio media, publishing houses and news agencies in the country.",215

The most recent overarching government development strategy called the National Peace and Development Framework, which is a five-year plan (2017-2021) intended to achieve "self-reliance" for the country in the areas of security, social and economic development,

\footnotetext{
${ }^{213}$ Mass Media Law of the Islamic Republic of Afghanistan, Ministry of Justice, 2009, Article 44, page 45, http://moj.gov.af/content/files/OfficialGazette/0901/OG_0986.pdf, (Retrieved 15 July 2017)

${ }^{214}$ Author interview with Afghan journalist in Kabul, 2 May 2017

${ }^{215}$ President Ghani, through an order, waives previous outstanding tax dues of print and audio media, news agencies and publishing houses, Office of the President of the Islamic Republic of Afghanistan, 29 August 2017, http://president.gov.af/fa/news/333231, (accessed 22 September 2017)
} 
acknowledges the role of Afghan media and civil society groups in the country's development. "Both as watchdogs and as partners, civil society organizations (CSOs) and the media make significant contributions to Afghanistan's stability and development." The document also commits the Afghan government "to support direct donor financing for human rights workers, press and media development."216

\subsection{Advertising}

In 2010, the total advertising market in Afghanistan was estimated to be around $\$ 37$ million. ${ }^{217}$ According to a 2009 study, up to 90 percent of advertising expenditure came from banks, telecommunications companies and construction firms. However, the study also noted, "Businesses are slowly starting to advertise consumer products.",18

Given the small size of the proverbial pie, competition for advertising dollars is intense. "Although trade and economic activities in Afghanistan have been on a growth parth in the last 15 years, the advertising market has not grown in tandem with the growth of economic activities," said a research participant who works in print media. "Afghan media outlets are in stiff competition among themselves over the small sums in the advertising market. This is especially true in the case of independent private media outlets that solely rely on advertising revenue for their operations."

\footnotetext{
${ }^{216}$ Afghanistan National Peace and Development Framework (ANPDF) 2017 to 2021, Afghanistan Permanent Mission to the United Nations, Government of the Islamic Republic of Afghanistan, page 31, http://afghanistan-un.org/wp-content/uploads/2016/10/ANPDF.pdf, (accessed 23 July 2017)

${ }^{217}$ Afghan Media in 2010: A Synthesis Report, Altai Consulting, pages 68, 69, http://www.altaiconsulting.com/wp-content/uploads/2016/03/Afghan-Media-in-2010.pdf, (accessed 8 July 2017)

${ }^{218}$ Jean Fairbairn, Community media sustainability guide: The business of changing lives, Internews, 2009, page 69, http://www.amarc.org/documents/manuals/InternewsCommunityMediaGuide2009.pdf, (accessed 25 July 2017)
} 
The research participant said the government could not interfere in advertising revenue allocation among media outlets. "The government cannot interfere in the private advertising market or institute a law for the fair distribution of advertising," he said. "That's because revenue amounts going to media outlets is determined by the performance and audience size of each outlet.",219

The Altai 2010 assessment estimated total revenues in the Afghan media sector that year to be between $\$ 75$ million and $\$ 95$ million, about half of them coming from advertising. ${ }^{220}$

The advertising pie has gotten smaller with the marked deterioration in the security situation starting in 2014, which coincided with the withdrawal of the bulk of foreign troops from the country. A research participant said this has resulted in fewer and fewer businesses spending money on advertising. "The reason is because security is the main problem, which doesn't allow for investments and business activities and trade," he said. "When this happens, there is no need for ads. When security improves, then the economy will grow and ads will come."221

Another research participant said advertising for traditional media had also dwindled because of the loss of some audience numbers to web-based platforms. "The rapid rise of the internet brought down rates of advertising for conventional media globally. This is happening here, too. Few years ago, people didn't get information from the internet but

\footnotetext{
${ }^{219}$ Author interview with Afghan journalist in Kabul, 2 May 2017

${ }^{220}$ Afghan Media in 2010: A Synthesis Report, Altai Consulting, pages 79, http://www.altaiconsulting.com/wp-content/uploads/2016/03/Afghan-Media-in-2010.pdf, (accessed 8 July 2017)

${ }^{221}$ Author interview with Afghan journalist in Kabul, 7 May 2017
} 
mainly from TVs, radios and papers. But these are now struggling to get advertising," he said. "You must have massive investments in the country to have advertising for media. Right now, media outnumber investors and businesses starting up in the country."222

The evidence shows that Afghanistan has yet to develop a mature media advertising market. "The advertising market in Afghanistan has never been stable in the past 16 years," said a research participant. "This is because of the instability of the economy and the fluctuating levels of international aid." ${ }^{223}$

Looking at the bigger picture, advertising, which is dominated by a small number of major media outlets, constitutes only one source of funding for media outlets in Afghanistan's peculiar economic environment. The Altai 2010 study identified "political parties, ethnic groups, the military and neighbouring countries, as well as international donors" as the other major sources of funding and financial assistance for media outlets, depending on their ownership and editorial bent. ${ }^{224}$

Grant assistance provided by Western donor countries constitutes a major portion of funding for independent print media and community radio stations. It is impossible to tally the total amount of donor money invested in this sector since 2002 because no consolidated reliable statistics exist in this area.

\footnotetext{
${ }^{222}$ Author interview with Afghan journalist in Kabul, 30 April 2017

${ }^{223}$ Author interview with Afghan journalist in Kabul, 8 July 2017

${ }^{224}$ Afghan Media in 2010: A Synthesis Report, Altai Consulting, page 26, http://www.altaiconsulting.com/wp-content/uploads/2016/03/Afghan-Media-in-2010.pdf, (accessed 8 July 2017)
} 
However, at least some figures are available about the largest donor in this area, the United States Agency for International Development. According to a 2005 assessment of USAID assistance to the media sector, the agency had invested some $\$ 15$ million "in the development of free and independent media in Afghanistan." 225 In subsequent years, USAID increased its support substantially. For example, the agency granted \$22 million to various media development projects in 2010 alone. ${ }^{226}$ Extrapolating from this, it is easy to assume that the total figures are not insignificant at all.

A research participant said because of the drop in other revenue sources, such as advertising, independent Afghan media outlets will require years of international donor support. "The international community should continue assisting the media sector especially by providing funds for programming production in independent free media whose news and current-affairs programming may not generate enough revenue," he said. $^{227}$

The third stream of funding for media outlets comes from owners and other political supporters of partisan media. These include powerful local strongmen and their regional backers, especially neighbouring countries that have long interfered in the country's

\footnotetext{
${ }^{225}$ Colin Soloway and Abubakar Siddigue, USAID's assistance to the media sector in Afghanistan, October 2005, PPC evaluation paper No. 3, Bureau for policy and program coordination, USAID, page 11, http://pdf.usaid.gov/pdf_docs/PNADC219.pdf, (accessed 14 August 2017)

${ }^{226}$ Afghan Media in 2010: A Synthesis Report, Altai Consulting, page 34, http://www.altaiconsulting.com/wp-content/uploads/2016/03/Afghan-Media-in-2010.pdf, (accessed 8 July 2017)

227 Author interview with Afghan journalist in Kabul, 18 May 2017
} 
affairs. ${ }^{228}$ Altai estimated these figures to be $\$ 14$ million - \$19 million and \$6 million $\$ 7.5$ million each in 2010 , respectively. ${ }^{229}$

\subsection{Conclusion}

Based on this evidence, it is fair to say that Afghanistan does possess a diverse media sector with dozens of TV channels, radio stations and hundreds of print publications. However, views in Afghanistan on this phenomenal growth in the number of media outlets and the diversity and pluralism that they represent and advance, though broadly positive and supportive, are mixed. There is a consensus that the overall growth is a net gain for press freedom and freedom of expression and, as a result, for the promotion of the goal of an open and democratic country.

On the other hand, it was easy to detect during the course of the research, especially in many of the research interviews, a current of concern about the polarization of the broadcast media largely on account of the entry of highly partisan/party-affiliated TV channels onto the media scene, the lack of diversity and variety in media content throughout the entire spectrum of the media sector as well as an absence of proactive support from the government in promoting content pluralism and diversity.

It is also important to note the choice that this diversity presents to the Afghan public who until a mere fifteen years ago had to largely endure state propaganda from the

\footnotetext{
${ }^{228}$ The media of Afghanistan: The challenges of transition, BBC Media Action, March 2012, page 9, http://downloads.bbc.co.uk/mediaaction/policybriefing/bbc_media_action_afghanistan_is_in_transition.pdf , (accessed 4 July 2017)

${ }_{229}$ Afghan Media in 2010: A Synthesis Report, Altai Consulting, pages 79, http://www.altaiconsulting.com/wp-content/uploads/2016/03/Afghan-Media-in-2010.pdf, (accessed 8 July 2017)
} 
limited state-media outlets that existed in the country. At the same time, the current Afghan government, despite its numerous shortcomings with regards to more proactively supporting media pluralism and diversity, is starting to push for a more level playing field and better working conditions for journalists and media workers, especially when it comes to the financially more vulnerable media outlets in the print and radio sectors. In general, however, the challenge of dwindling advertising revenues and declining international assistance pose a formidable challenge to the continued survival and further development of independent media outlets. If the overall economic situation in Afghanistan does not improve in the years to come, this challenge can become increasingly acute.

At the same time, the findings highlighted the absence of a real diversity of content in the Afghan media landscape, which is a matter that requires ongoing work on the part of the media sector, the government and international donors. The chapter also underlined the threat posed to the independent media sector's credibility by partisan media outlets that are much less objective in their coverage. However, as pointed out by several research participants, it is encouraging to note the Afghan public is increasingly able to distinguish the political and ideological orientation of partisan media outlets and take them more as official information channels instead of considering them as independent media outlets. 


\section{Chapter: MEDIA AS A PLATFORM FOR DEMOCRACY}

This chapter will review and assess the Afghan news media in light of Category 3 of the UN's Media Development Indicators: Media as a platform for democracy. As such, the chapter will examine one of the essential roles of an independent media, i.e. its role as a platform for democratic debate and its impact on strengthening the tenets and foundations of democratic governance and an open society. It will assess the Afghan media's specific role in responding to the Afghan public's key concerns, perceptions and needs, for example on issues related to the population's social and political needs such as healthcare, education, political participation, tackling of government corruption, etc. It will also assess the role of the media in supporting the struggles of Afghan women, who still do not enjoy equal status with men when it comes to their social, economic and political role in the country, for a better deal. This will be done in part by taking into consideration evaluations of the level of public trust in the media. In doing so, the chapter will also look at how representative the Afghan media sector itself is of the diversity of Afghan society in terms of hiring practices, the safety and security environment for journalists in the country as well as the existence and extent of adherence to standards of impartiality and fairness as well as self-regulation rules. The chapter will also look at the success or failure of efforts so far aimed at the establishment of a credible public broadcasting service, unencumbered by direct government control.

\subsection{Media reflects diversity of society}

The National Media Summit, a major gathering of Afghan journalists in Kabul in July 2007 demanded that, among others, Afghan government policy towards journalism and 
the media be guided by the principle "that media, whatever the mode of dissemination, are independent, tolerant and reflect the diversity of opinion enabling full democratic exchange within and among all communities, whether based on geography, ethnic origins, religious belief or language.,"230

It can be argued that Afghan media has played a significant role in the developments and changes that have occurred in the country since the fall of the Taliban regime. As a 2013 study on civil society development in the country noted, "Assisted by civil society organizations and international donors, Afghanistan has developed a functioning independent media, able to act as a government watchdog, inform Afghans on important topics, provoke social debate and help increase civic engagement."231

In the past 15 years, members of Afghan civil society organizations have often participated at international conferences on Afghanistan as guests, and given a chance to present the views and demands of the country's civil society. At a major global economic development conference in Tokyo in 2012, the civil society activists spoke about the role of media in the country's development. "The free and independent media, as the voice of civil society, supporter of democracy and defender of human rights, has played a crucial role in development of a democratic Afghanistan."232

\footnotetext{
${ }^{230}$ Media for democracy in Afghanistan, International Federation of Journalists, page 26, http://www.ifj.org/uploads/media/110-Afghanistan-media_for_democracy.pdf, (accessed 15 August 2017) ${ }^{231} 2013$ Afghanistan civil society assessment, Langer Research Associates for Counterpart International, January 2014, page 102, http://www.langerresearch.com/wp-content/uploads/IPACS_II_Report_Web_Final.pdf, (accessed 18 July 2017) ${ }^{232}$ Demands of Afghanistan civil society on the occasion of Tokyo Conference on Afghanistan, 8 July 2012 ,
} 
A prominent and important example of this is the media's role in the country's political processes over the past fifteen years, especially during elections.

Freedom House, in its 2015 annual report, said the presidential election campaign in 2014 "was replete with robust coverage via radio, television, newspapers, and the web, and the first ever televised presidential debate.,"233

In order to ensure coverage of issues important to the electorate, the country's largest news agency, the independent Pajhwok News Agency, issued a detailed "journalists" guide about reflecting the demands and views of the people" ahead of the 2014 elections. Pajhwok said the guide's purpose was "to identify people's problems, inform candidates about people's problems and the country's next president solve these problems." The guide advised reporters to ask questions such as 'what change has occurred in your life compared to five years ago,' 'in the area where you live, what is the major and top problem of the people,' 'how much do you trust the upcoming elections,' 'if you meet with the president, what will be your top request, message and criticism,' etc. To ensure reporters canvassed the diversity of Afghan society, the guide specifically advised reporters that "for interviews experts, politicians, poor people, farmers, school students,

https://www.boell.de/sites/default/files/assets/boell.de/images/download_de/worldwide/AfghanistanCivilSo cietytoTokyo.pdf, (accessed 15 July 2017)

${ }^{233}$ Freedom in the World 2015: Afghanistan, Freedom House, https://freedomhouse.org/report/freedomworld/2015/afghanistan (Accessed 22 August 2015) 
housewives, liberate and entrepreneurs should be selected. Also, interviews should not neglect minorities and people of various ethnic groups should be interviewed."234

One of the main independent election monitoring organizations in the country, the Transparent Election Foundation of Afghanistan, wrote a detailed assessment of the 2014 presidential election. In it, the organization credited the role of the media for the high voter turnout. "No doubt, the media played a notable and prominent role in publishing and broadcasting election-related news, increasing public awareness about the elections and introducing the candidates and their programs to the people. The media reflect and analyze the views of different political parties, groups and factions which is a prominent symbol of a democratic system and approach, and which facilitates public participation." TEFA said. "This issue is a factor in the increase in people's participation in the elections. ${ }^{, 235}$

Afghanistan's current president, Mohammad Ashraf Ghani, who won the contested 2014 elections, spoke about the media's role during the campaign. In a speech to the New York-based Atlantic Council on 30 May 2014 during the height of the run-off election campaign, presidential Ghani said he was "struck - dumbstruck -- by the extent to which the presidential debates were watched across the country and weighed, and on that basis

\footnotetext{
${ }^{234}$ Journalists guide about reflecting the demands and views of the people, Pajwok Afghan News, 2014, http://www.elections.pajhwok.com/dr/content/رنمود-خبرنغار ان-درمورد-انعكاس-خو استه_ها-و -نظريات_مردم, (accessed 2 August 2017)

${ }^{235}$ Report on lessons learned in the elections, Transparent Elections Foundation of Afghanistan, Kabul, 8 June 2014, http://www.elections.pajhwok.com/dr/node/15036, (accessed 4 July 2017)
} 
decisions were made. A free media of course also has rough edges, but by and large the nature of public discourse in Afghanistan has been remarkable."236

A research participant said the diversity of media outlets in the country allowed for the population to get exposed to a diversity of views. "You have to switch the different channels that exist to understand different parts and tribes of the country and their political views," he said. "This diversity reflects the country.",237

Another research participant said "the only institution that can well represent and reflect the diversity of Afghan society is the media. Media outlets are established and operate in different languages, according to diverse majority and minority cultures and the size of their audience groups." The research participant said Afghanistan's independent media sector constitutes "one of the strongest pillars of democracy and freedom in Afghan society." "Freedom of expression and freedom the press are phenomena in Afghanistan that have granted dignity and a good name to the country and have placed Afghanistan in a better light. This achievement must be preserved."238

Remote rural populations that do not have or cannot afford easy access to broadcast media centred in the major cities can instead rely on the network of local radio stations throughout the country. A good example of this is a network of nearly 40 radio stations which Internews launched in 2002 that reaches more than one third of the population. In

\footnotetext{
${ }^{236}$ A conversation with Afghanistan Presidential Candidate Dr. Ashraf Ghani, Atlantic Council, 20 May 2014, http:/www.atlanticcouncil.org/news/transcripts/dr-ashraf-ghani (Accessed 20 August 2017).

${ }^{237}$ Author interview with research participant in Kabul, 30 April 2017

${ }^{238}$ Author interview with research participant based in Kabul, 2 May 2017
} 
addition to dealing with local news and issues, radio stations in the network receive programming on "development and democracy" from a central production house set up in Kabul called Salam Watandar. By 2009, radio stations in this network received 14 hours of programming daily. ${ }^{239}$

A research participant who helped Internews set up many of the local radio stations described the process. "For example, we established a radio station in Badakhshan and we went there and told the people we want to establish a community radio but that they should contribute the land and half the building costs of the station. We also told them the community should appoint a director and there should be a community board to make sure programming responds to the needs of the people," he said.

The research participant said these local outlets required ongoing government support for their long-term survival. "The government should provide subsidies for example electricity subsidy, for solar power or from the national grid. This will help local and community media outlets a lot. Also, the urban development and rural development ministries should go to local media outlets and give them their public service ads to help local media outlets to survive. This will encourage further diversity and everybody will see themselves reflected in the media sector." 240

\footnotetext{
239 Jean Fairbairn, Community media sustainability guide: The business of changing lives, Internews, 2009, page 67, http://www.amarc.org/documents/manuals/InternewsCommunityMediaGuide2009.pdf, (accessed 25 July 2017)

${ }^{240}$ Author interview with research participant based in Kabul, 7 May 2017
} 


\subsection{Media, women's participation and hiring practices}

Afghan women were banned from participation in public life under the Taliban. This has significantly changed in the years since the Taliban regime was toppled in 2001. And Afghan media have played an important role in promoting women's participation in society by changing public perceptions. Research has shown that people who get their information from the media hold more liberal views towards women's role outside the confines of the home. For example, the Asia Foundation survey in 2017 found that 90 percent of internet users and 93 percent of TV viewers "believe women should be allowed to vote" while 50 percent of internet users and an equivalent percentage of TV viewers "say positions of political leadership should be filled by both men and women. By comparison, 80 percent of radio listeners said women should have the right to vote and another 40 percent supported women's participation in leadership positions.",241

These figures may be in response to the prominent focus media outlets have put on promoting the cause of women's rights. For instance, virtually all of the major TV channels in the country run prominent programs devoted to women's needs and the challenges and problems they continue to face in Afghanistan's conservative, maledominated society. According to an independent survey of the Afghan media in 2015, programs featuring women's issues ranked fourth in terms of audience preferences after

\footnotetext{
${ }^{241}$ A survey of the Afghan people 2017, The Asia Foundation, Kabul, page 13, 14 November 2017, https://asiafoundation.org/wp-content/uploads/2017/11/2017_AfghanSurvey_report.pdf, (accessed 18 November 2017)
} 
soap operas, news and entertainment programs. ${ }^{242}$ Tolo TV, the largest private channel, runs several women-focused programs such as Banu (Lady), a live call-in show. According to the same survey cited above, Banu is "by far the most consistently watched and liked program by women.,243

Afghan women have played an increasingly important role as journalists, too. As reported in the previous chapter, 2,366 or 17 percent of the 12,553 journalists who worked in Afghanistan in March 2017 were women. As one research participant pointed out, "this is a new phenomenon - for women to work in the media sector."244

As reported in the previous chapter, there are a number of media outlets that focus on issues related to social minority groups such as the disabled. However, based on research for this project, the representation of other ethnic and social minority groups as journalists is largely symbolic. The research also revealed a difference in terms of the ability of women journalists to work in cities versus rural areas.

For example, a research participant said that "media outlets are not observant in ensuring diversity in their hiring practices because most media outlets cater to specific social groups. Large media outlets and those that cover the entire country adhere to balanced hiring but media outlets that operate in specific geographical and linguistic spheres

\footnotetext{
${ }^{242}$ Afghanistan Media in 2014: Understanding the Audience, Altai Consulting, February 2015, page 160, http://www.altaiconsulting.com/wp-content/uploads/2016/05/Altai-Internews-Afghan-Media-in-2014.pdf, (accessed 7 July 2017)

${ }^{243}$ Afghanistan Media in 2014: Understanding the Audience, Altai Consulting, February 2015, page 149, http://www.altaiconsulting.com/wp-content/uploads/2016/05/Altai-Internews-Afghan-Media-in-2014.pdf, (accessed 7 July 2017)

${ }^{244}$ Author interview with research participant based in Kabul, 7 May 2017
} 
usually hire their workers from their own areas and languages." The research participant also said the main reason for the low participation of women in the media sector was cultural restrictions on the movement of women that still persist. "Given the nature of media work, Afghan women cannot stay at work late or go to insecure areas for reporting," he said. ${ }^{245}$

Another research participant said "the participation of women in the media is good only in Kabul and in the northern provinces. In Pashtun areas, the rate is very low."246

As an example, a research participant familiar with the situation said there is only one female journalist working in the south-central province of Uruzgan who is employed by the local RTA station.

This research participant also said "I don’t see much diversity in hiring." However, he distinguished lack of diversity in two ways. He said media outlets in areas where the speakers of one of Afghanistan's many languages predominated, lack of diversity didn't have a negative effect. He mentioned the Pashto-majority eastern province of Khost and the Dari-majority northeastern province of Badakhshan as examples. "In Khost, there is no need to have ethnic diversity. All journalists working there can be Pashtun. The same in Badakhshan where most speak Dari."

\footnotetext{
${ }^{245}$ Author interview with research participant based in Kabul, 2 May 2017

${ }^{246}$ Author interview with research participant based in Kandahar, 9 May 2017
} 
Lack of diversity in hiring at national media outlets, on the other hand, especially those in Kabul and other major cities, he said, undermined the country's unity. "This is a problem. I mean diversity in any area will help the country to develop. You'll have wider thinking and development. When there is diversity, it shows there is no problem among the ethnic groups but now we can see the opposite."

However, the research participant said this lack of diversity in hiring wasn't limited to the media. "If you go to NGOs and businesses, there is no diversity in hiring. This is a big challenge. If we can address this, Afghanistan will become calm and peaceful," he said. "Even with the government, if a minister belongs to one ethnic group, most senior people will be from his ethnic group. And when he goes from one ministry to another, most of his people will follow him there.,247

Another research participant said ownership played the biggest role in why media outlets don't recruit diverse pools of journalists. "A lot of media outlets are in the hands of politicians and tribal leaders and businesspeople," he said. "Some are trying to bring some balance but overall it is not balanced., 248

Another research participant said the only media outlets that ensure a level of diversity in their hiring are the independent ones. "Ethnic and ideological media give preferences to those they think are of their caste or group or ideology."249

\footnotetext{
247 Author interview with research participant based in Kabul, 7 May 2017

${ }^{248}$ Author interview with research participant based in Kabul, 30 April 2017

${ }^{249}$ Author interview with research participant based in Kabul, 18 May 2017
} 


\subsection{Public service broadcasting model}

The Mass Media Law of Afghanistan states that Radio Television Afghanistan (RTA), the state-owned broadcaster, is "a mass media outlet belonging to the Afghan nation which functions as an independent department within the executive branch of the government." The reference in the law to RTA's independence at a time when its management and funding is controlled by the executive branch gives away the inherent contradiction in the law and makes it clear that turning this state-owned entity into a true public broadcaster will not be easy.

Nonetheless, there are two additional stipulations elsewhere in the Mass Media Law that could eventually aid the work of helping RTA gradually evolve into a trusted public broadcaster. The first stipulation is that RTA "shall organize its programming in observance of complete impartiality toward ensuring national unity and strengthening the religious and national values of the country in a way that is reflective of the culture, language and religious beliefs of all the ethnic groups of the country."

The second stipulation, perhaps more significant, establishes an "RTA Commission" comprising a religious scholar, a legal expert, an engineer, a journalist, an artist, a civil society activist and a member of the RTA management team for a total of seven members elected for three-year terms. The commission's duties and authorities include "ensuring the independence, impartiality and professional character" of RTA, monitoring the implementation of RTA's budget and its charter as well as guidance issued by the High 
Media Council and attracting assistance from donor countries for the development of RTA. $^{250}$

The chief obstacle to this evolution of RTA, established as the first TV channel in the country in 1976, into a public broadcaster independent of the whims of the government has been the unwillingness of multiple ministers of information and culture to support such a change. This has led to a long process of delay in this regard. ${ }^{251}$ As stated in the previous chapter, the present-day reality of RTA being seen as a government mouthpiece is even causing frustration and resistance within the institution itself, which might actually be early indications of growing momentum for change. A respected director general of RTA was forced to resign in 2007 mainly because he clashed with the then Minister of Information and Culture over the extent of RTA's independence from government diktat. ${ }^{252}$

There was broad consensus among the research participants on RTA's status as a government-controlled outlet which has a long way to go before it can be regarded as a reliable public broadcaster. For example, a research participant in Kabul said, "We don't have public media. RTA should be a public media, but it's controlled by the government." The research participant said he believed it was eminently possible to rapidly turn RTA

\footnotetext{
${ }^{250}$ Mass Media Law of the Islamic Republic of Afghanistan, Ministry of Justice, 2009, Articles 14, 16, 44, pages 15, 17, 36-38, http://moj.gov.af/content/files/OfficialGazette/0901/OG_0986.pdf, (Retrieved 15 July 2017)

${ }^{251}$ Afghan Media in 2010: A Synthesis Report, Altai Consulting, page 26, http://www.altaiconsulting.com/wp-content/uploads/2016/03/Afghan-Media-in-2010.pdf, (accessed 8 July 2017)

${ }^{252}$ Ramin Anwari, Director general of RTA resigns, BBC Persian, 24 July 2007, http://www.bbc.com/persian/afghanistan/story/2007/01/070124_ram-roshan-resign.shtml, (accessed 5 August 2017)
} 
from a media outlet seen by everyone as a government mouthpiece to a respected, professional public broadcaster. He said: "RTA has good technical resources. What it needs are good human resources and the regulatory framework to allow it to function as an independent public broadcaster but there hasn't been any political will [on this] going back to 2002." He said there was keen interest among many donor countries to support this process; however, "no one in the government was interested in this.",253

Another research participant agreed, calling RTA "pure government." "Sometimes it's used as a tool of propaganda by the government, always by the government." He also lamented the missed chance of the past several years when international support could have turned RTA around. "There was a lot of talk and debate a few years ago to turn RTA into a public broadcaster but it didn't work. Most of the time the government doesn't want to lose this kind of tool that they have," he said. "No model of BBC here right now." The research participant underlined the role of civil society and country-wide consultations to exert the necessary pressure for creating a public broadcaster. "We have to have this debate so that we aren't just business-oriented or government-controlled. We should have a true public broadcaster. This needs society-wide discourse and this needs to include the government for it to see the need for this kind of outlet., ${ }^{254}$

Another veteran Afghan journalist who has been part of civil society efforts to lobby for the establishment of a public broadcaster also expressed his dismay at the result of such efforts so far. "Public service broadcasters never came into being. The so-called national

\footnotetext{
${ }^{253}$ Author interview with research participant based in Kabul, 7 May 2017

${ }^{254}$ Author interview with research participant based in Kabul, 30 April 2017
} 
broadcasters (RTA main and local stations) are literally controlled and abused by the government officials. ${ }^{255}$

Another research participant noted that the country doesn't have a public broadcaster 'in the true meaning of the word," elaborating that "RTA has not been able to turn itself into a good public broadcaster and only focuses on broadcasting government news as the government's propaganda apparatus." He said that among other things RTA must become much more representative of the diversity of the country to become a public broadcaster. "Public broadcasters must be able to reflect, in a balanced way, the languages, cultures and characteristics of the society, which is something that we don't yet have in our statefunded media outlets. ${ }^{, 256}$

A research participant based in the eastern city of Jalalabad pointed to the challenge of self-censorship even within the RTA. "The national broadcaster is in the monopoly of the government and its broadcasts on many occasions is unbalanced and one-sided. Selfcensorship can also be observed among national broadcasters because of interference from the government. ${ }^{, 257}$

However, an Afghan independent journalist and media activist who has worked closely with the government on a variety of issues related to press freedom drew a distinction between RTA being an out of date media outlet and its efforts to at least represent the

\footnotetext{
${ }^{255}$ Author interview with research participant based in Kabul, 18 May 2017

${ }^{256}$ Author interview with research participant based in Kabul, 2 May 2017

${ }^{257}$ Author interview with research participant based in Jalalabad, 8 May 2017
} 
various segments of Afghanistan's diverse population. "The public service broadcasting model is old-fashioned and ineffective. The news they produce mainly reflects activities of the government. The entertainment content they produce is also old-fashioned and best suits the tastes of the older generation. These are the main reasons behind their failure to attract audiences," he said. However, he said RTA stations throughout the country "do not discriminate against any particular group. They have made an effort to accommodate content in various languages of the country." ${ }^{, 258}$ As noted in the previous chapter, RTA allocates 20 percent of its broadcast time to the country's minority languages such as Uzbek, Turkmen, Pashai and Baluchi, while 80 percent of airtime goes equally to the country's two national official languages, Pashto and Dari, respectively.

Another journalist drew an interesting contrast between the partisan and state-owned TV channels where he favoured the latter model. "There are many media outlets that promote regional and linguistic prejudice but the media outlets that are funded by the government are to a large extent restrained [in this regard]," he said. ${ }^{259}$

A veteran journalist and media activist questioned the government's use of public money for its narrow propaganda purposes. "This is an issue which we have to address because in a democratic society, a state shouldn't have a media outlet carrying out propaganda for it," he said. "RTA is funded through public taxes so the question is why should people's money be spent on government propaganda?"260

\footnotetext{
${ }^{258}$ Author interview with research participant based in Kabul, 8 July 2017

259 Author interview with research participant based in Kabul, 9 May 2017

${ }^{260}$ Author interview with research participant based in Kabul, 7 May 2017
} 
In September 2017, Mohammad Sarwar Danesh, the Second Vice President of Afghanistan, spoke at a public event celebrating the $90^{\text {th }}$ and $40^{\text {th }}$ anniversaries of Radio Afghanistan and Television Afghanistan, respectively, in Kabul. In a major speech on press freedom and media development in the country, Danesh also conceded that RTA has yet to fulfil its mission as a credible public broadcaster. Urging the management of RTA to enhance the channel's "attractiveness" to audience groups, Danesh said RTA "as is clear from its name, must also be national in practice." "Although this institution, in terms of its budget and structure, is a government institution and should reflect the government's programs and official reports sufficiently, it should not act like a government outlet," he said. "It must put the interests of the nation and people of Afghanistan at the top of its priorities and should deal with events in the country in an inclusive national, non-ethnic and impartial manner. This institution is a wide mirror for the common history, culture, civilization and values of all the people of Afghanistan.",261

\subsection{Media self-regulation}

Several attempts were made over the past decade or so to institute some form of selfregulation within the Afghan media sector. These included attempts to write various codes of conduct and ethics, mainly led by independent Afghan journalists and media support organizations. Some of these documents were distributed to limited numbers of media outlets. For example, in 2009, Internews, an international media support

\footnotetext{
${ }^{261}$ Speech of Sarwar Danesh, Second Vice President, at the 90th anniversary of the establishment of Radio Afghanistan and the 40th anniversary of the establishment of Television Afghanistan, Office of the Second Vice President, 21 September 2017, https://vpo.gov.af/18-بيانيه_استاد_سرور-دانش-معاون-دوم-رئيس/, (Accessed 25 September 2017)
} 
organization with offices in Kabul, put together a code of ethics and distributed it widely among journalists, mainly in the capital. ${ }^{262}$ Still others were drafted but never implemented. ${ }^{263}$ However, between 2013 and 2016, the Afghanistan Journalists Federation led the drafting of a consensus code of ethics for use by journalists throughout the country. Following widespread consultations across several provinces and media outlets with more than 400 journalists, the Federation finally launched a uniform National Code of Ethics for Afghan journalists in May $2016 .^{264}$

The code covers topics ranging from accountability, impartiality and balance in reporting to reduction of risk, authenticity and professional behavior in the field. For instance, the code specifies that journalists must identify their sources clearly, never distort facts, refuse all types of bribes and acknowledge mistakes and correct them promptly. The code also advises journalists not to bow to pressure from the government, other individuals or groups, and to publish news only after confirming the credibility of their information and sources. It also underlines the need for reporters to protect individuals' privacy and to avoid interviewing underage children, especially when they are victims of violence,

\footnotetext{
${ }^{262}$ Internews Afghanistan: Risk management toolkit, code of ethics and a new radio station, Internews Network, 30 April 2009, https://reliefweb.int/report/afghanistan/internews-afghanistan-risk-managementtoolkit-code-ethics-and-new-radio-station, (accessed 16 September 2017)

263 Joint committee drafts code of ethics for Afghan journalists, United Nations Assistance Mission to Afghanistan, 23 April 2013, https://unama.unmissions.org/joint-committee-drafts-code-ethics-afghanjournalists, (accessed 16 September 2017)

${ }^{264}$ Draft of code of journalism ethics is approved, Radio Azadi, 26 May 2016, https://da.azadiradio.com/a/27756461.html, (accessed 16 September 2017)
} 
without first obtaining the permission of an adult family member. The code also calls for the creation of safe working environments, especially for women journalists. ${ }^{265}$

The national code of ethics was announced days after the country's president, Mohammad Ashraf Ghani, renewed his call on the media sector to devise a code of ethics. Ghani had said the government would not interfere in the writing of the code as that could be seen as an attempt to censor or influence the document. ${ }^{266}$

The fact that more than 400 Afghan journalists from the four corners of the country managed to participate in a consultative process and finalize a uniform set of ethics rules is a significant achievement in and of itself. Nevertheless, based on the interviews conducted for this research project both in Kabul and in some of the country's provinces, it was quite clear that the code's implementation, at least so far, has lagged.

A research participant, who was part of the national consultation process for the ethics code, said "the only rule that media outlets have themselves is media ethics, which is not a binding rule." He went on to say that even today "every media organization has their own set of internal regulations but we don't yet have any type of self-regulation rules that all media outlets have created which they would follow." 267

\footnotetext{
${ }^{265}$ Afghan journalists approve national code of ethics, Afghanistan Journalists Centre, 25 May 2016, http://afjc.af/english/index.php/af-media-news/central-provinces/kabul/597-afghan-journalists-approvenational-code-of-ethics.html, (accessed 16 September 2017)

${ }^{266}$ Ghani asks journalists to determine the limits of freedom of expression, BBC Persian, 4 May 2016, http://www.bbc.com/persian/afghanistan/2016/05/160504_k04_ghani_to_address_press_freedom_day_cere mony, (Accessed 16 August 2017)

267 Author interview with research participant based in Kabul, 2 May 2017
} 
Another research participant said some media outlets are developing their own codes of conduct "which regulates their professional work in terms of news and content production," but that most outlets still lack such "self-regulatory mechanisms." However, he thought that having an editor review all of the content before being broadcast is another safety mechanism. ${ }^{268}$

A veteran Afghan war reporter said the main reason for the patchy adherence of Afghan journalists to self-regulating codes of conduct and journalism ethics was mainly a question of time. By this he meant that despite 15 years of development, the independent Afghan media sector is still nascent and needs a few more years to mature in this regard. "Definitely I do hope there will be self-regulation. The beginning of the independent media in Afghanistan was such that many people jumped into it without any experience or expertise but now progress will be more normal and there will more self-regulation," he said. "We hope that the journalists community will bring better self-regulation by practicing the ethics of journalism. We have to bring up the culture of respecting ethics of journalism in Afghanistan. This is something that is lacking right now."269

\footnotetext{
${ }^{268}$ Author interview with research participant based in Kabul, 8 July 2017

${ }^{269}$ Author interview with research participant based in Kabul, 30 April 2017
} 
In a similar vein, a former journalist and media activist who was directly involved in the drafting of the national code of ethics said more and more media outlets are adopting the code, but that there was still a long way to go. "Still there is need for more improvement in the code of conduct and journalists should be encouraged and their awareness raised about following the code of conduct," he said. ${ }^{270}$

\subsection{Requirements for fairness and impartiality}

Apart from the Mass Media Law itself, the scant reference to rules pertaining to journalists' obligations with regards to upholding impartiality and fairness appear in the bylaw on the registration and operation of private media introduced in 2016 (see Chapter 4). The bylaw states that reporters have an obligation toward their employers for "observing the principle of impartiality." ${ }^{271}$ The only other reference in official government sources found was an almost passing reference to the need for maintaining "balance" in reporting in a Ministry of Information and Culture press release in the summer of 2017. The roughly page-long press release stated in a single sentence: "All journalists are requested to prepare their news and reporting in a professional and balanced manner." 272 Further extensive research for this project did not find any other official document that outlines clear principles and requirements for ensuring the principles of impartiality and fairness.

\footnotetext{
${ }^{270}$ Author interview with research participant based in Kabul, 7 May 2017

${ }^{271}$ Bylaw for the operation of private mass media, Article 40, Bakhtar News Agency, Ministry of Information and Culture, http://bakhtarnews.com.af/dari/culture/item/1355--مقررة-فعاليت_رسانه_هاى_همخانى خصوصي.html?tmpl=component\&print=1, (accessed 24 July 2017)

272 Press release of the Ministry of Information and Culture's commission on assessing media violations, 4 June 2017, http://moic.gov.af/fa/news/301632, (accessed 17 August 2017)
} 
Research interviews showed that views on impartiality and fairness in the Afghan media vary significantly. An Afghan media lawyer well versed in the country's media legal framework said that despite the lack of clear guidelines and regulations, at least some media outlets are starting to observe the principles of fairness and impartiality in their reporting. "There are media outlets which follow fairness and impartiality but there are media outlets that don't have any impartiality and they take sides on behalf of certain political parties or ethnic groups."273

A research participant based in the southeastern city of Ghazni pointed to challenges in this area and said the best way to address them was to codify "codes of ethics into the legal framework so that everyone cannot trample these principles easily." 274

A research participant from the eastern city of Jalalabad said "in a lot of cases media outlets put out seemingly balanced but unfair or even false reports due to ethnic, partisan or linguistic grudges." The solution in the view of this research participant was "strict monitoring by an independent and impartial commission. ${ }^{275}$ Another research participant too underlined the need for close monitoring of the media in terms of the observance of fairness and impartiality. However, this research participant drew a distinction between the conduct of private independent media outlets and partisan outlets in terms of their level of commitment to these principles. "Independent media outlets (i.e. those not backed by powerful individuals, political groups, parties and others) are the only media

\footnotetext{
273 Author interview with research participant based in Kabul, 7 May 2017

${ }^{274}$ Author interview with research participant based in Ghazni, 8 May 2017

${ }^{275}$ Author interview with research participant based in Jalalabad, 8 May 2017
} 
outlets that adhere to the principles of balance and impartiality in their reporting. These independent media outlets constantly strive to reflect the views of different sides in their reporting and to provide fair space to all and they pursue an unbiased approach," he said. "Other political and factional media outlets do not follow this principle. No doubt this situation is not positive for the future of the media and journalistic work. Principles of journalism and independent reporting must become common throughout the media sector and we must have active media monitoring institutions."276

A senior media activist in Kabul said that although the Mass Media Law and the National Code of Ethics include requirements for fairness and impartiality in reporting, these "are not being sufficiently exercised by journalists." "At the same time, Afghanistan lacks an independent, non-government intra-media supervisory body or mechanism to ensure impartiality and fairness are observed by journalists in their reporting," he said. "We need a strong independent, non-government supervisory mechanism to improve fairness and impartiality.",277

The veteran war reporter also agreed that Afghan media reporting falls short in terms of impartiality and fairness. However, he attributed this in large measure to the pressures of the dangerous security situation and political turmoil in the country. "The majority of [journalists] are not fair and impartial," he said. "A handful of them are trying to be impartial. The rest are under the influence of what's happening in the country. For example, a journalist in Kunduz in the heat of violence cannot be 100 percent

\footnotetext{
${ }^{276}$ Author interview with research participant based in Kabul, 2 May 2017

${ }^{277}$ Author interview with research participant based in Kabul, 8 July 2017
} 
impartial." 278 The reporter was referring to the northeastern city of Kunduz which saw intense violence in 2015 and 2016 when the city twice fell to the Taliban briefly. ${ }^{279}$ Several local journalists were forced to flee the city as a result of the fighting and sought shelter in Kabul, an episode discussed further below.

\subsection{Levels of public trust and confidence in the media}

Repeated surveys of public opinion in Afghanistan have shown a solidly high level of public trust in the country's independent media. This is a clear indication of the public's reliance on the media in their lives on a daily basis. Moreover, it could also be safely interpreted as a source of strong and continuing public support for the media sector.

The Asia Foundation has conducted an annual Survey of the Afghan People since 2004. This makes it a very useful yardstick to measure the population's views about a broad array of issues ranging from their views about the overall direction of the country and the security situation to levels of confidence in the government, judiciary and security forces. The survey also measures levels of public confidence in the Afghan media. The survey has shown consistent very high levels of trust and confidence among the Afghan people towards the country's media as a whole, as shown over an eleven-year period in Table 6 below.

\footnotetext{
${ }^{278}$ Author interview with research participant based in Kabul, 30 April 2017

${ }^{279}$ Karima Amini, Officials: Taliban are turning civilian houses into fighting positions in the battle of

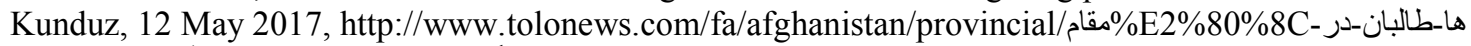

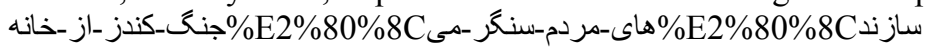


Table $6^{280}$ : Afghan peoples' levels of confidence in the country's media (2007-2017)

\begin{tabular}{|l|l|l|l|l|l|l|l|l|l|l|l|}
\hline Year & 2007 & 2008 & 2009 & 2010 & 2011 & 2012 & 2013 & 2014 & 2015 & 2016 & 2017 \\
\hline $\begin{array}{l}\text { \% of } \\
\text { confide } \\
\text { nce }\end{array}$ & 62 & 63 & 62 & 57 & 69 & 71 & 67 & 73 & 67 & 65 & 66 \\
\hline
\end{tabular}

According to the Asia Foundation survey for 2015, "media still remains the most trusted institution alongside religious leaders, and ahead of the government and non-government organizations. ${ }^{, 281}$ However, the media sector has relinquished the top position to religious leaders in the 2016 and 2017 surveys, which is perhaps not so surprising in a still largely religious and conservative society. However, there is a wide margin that separates confidence in the media in 2017 (66) percent versus confidence in members of parliament (35 percent), government ministers (35 percent) and the parliament as a whole (36 percent). ${ }^{282}$ There is no doubt this high rate of public confidence and support will be crucial for the long-term development and further entrenchment of independent media and its role in Afghanistan in the years to come.

Views among research participants were broadly in line with the findings of the Asia Foundation survey, with one significant difference, which became a recurrent theme

\footnotetext{
${ }^{280}$ A survey of the Afghan people 2017, The Asia Foundation, Kabul, page 98, 14 November 2017, https://asiafoundation.org/wp-content/uploads/2017/11/2017_AfghanSurvey_report.pdf, (accessed 18 November 2017)

${ }^{281}$ A survey of the Afghan people 2015, The Asia Foundation, Kabul, page 119, 17 November 2015, https://asiafoundation.org/resources/pdfs/Afghanistanin2015.pdf, (accessed 20 August 2017)

${ }^{282}$ A survey of the Afghan people 2017, The Asia Foundation, Kabul, page 10, 14 November 2017, https://asiafoundation.org/wp-content/uploads/2017/11/2017_AfghanSurvey_report.pdf, (accessed 18 November 2017)
} 
throughout the research period. Most research participants differentiated between independent media outlets which they noted enjoy much higher levels of trust and confidence on the one hand and partisan and state-owned media outlets which rank much lower on the trust and confidence scale, on the other.

For instance, a research participant based in Kabul said there was "good amount of public trust in the media." In the next breath, he added that "there is a major difference" between people's trust in independent media outlets versus state-owned ones. "This is because state-owned media outlets are seen as propaganda machinery of the government by most people," he said. ${ }^{283}$ A research participant from the southern Kandahar province said "there is confidence in the media but it differs. People trust those media outlets that express facts and realities. There is no trust in government media outlets because they promote the government's interests and hide the reality." 284

Another research participant said the Afghan public has become adept at differentiating between state-owned, partisan and independent media outlets, with independent media outlets enjoying the highest level of trust among the people. "The good thing is that a lot of people in Afghanistan can easily identify governmental media with which they don't agree. Among the private ones, which they also don't blindly agree with, some of them have earned respect and trust of the people," he said. "Once the public understands the nature of the media, they find their own outlets they trust."285

\footnotetext{
${ }^{283}$ Author interview with research participant based in Kabul, 8 July 2017

${ }^{284}$ Author interview with research participant based in Kandahar, 9 May 2017

${ }^{285}$ Author interview with research participant based in Kabul, 30 April 2017
} 
A research participant who has worked with community media outlets said "there is good confidence and trust in the media." He then gave examples of why people trust the media so highly in general. "There are cases where people had problems with the government in a local community and instead of going to the local police that person had gone to the media outlets with their complaint and had asked the reporters to do a report. In that way they wanted higher government authorities to address the issues. So the level of trust is very good. People trust the media because media has played a vital role in people's lives - during elections, through education programs, etc. People can distinguish between fair and impartial, independent media and partisan media outlets. They don't like partial media much."

The research participant also elaborated on the difference between state-owned and private outlets in this regard. "Yes, of course there is a difference in level of trust and confidence between state-owned and private outlets. People don't trust state-owned media because they say it's government propaganda. But they trust private media. That's true throughout the country. It's a very clear distinction," he said. "State media outlets don't have anything of value to broadcast - nothing in terms of education programs or anything else. People just watch state outlets for the news program so they find out about government policies, appointments, announcements of public holidays, etc. But other than that, people don't trust the state media for news or anything else."286

\footnotetext{
${ }^{286}$ Author interview with research participant based in Kabul, 7 May 2017
} 
According to the Afghanistan Journalists Centre, media has had a significant role in people's lives and in the country's development. It a commentary published in 2011 , it said "in the past ten years, media in Afghanistan have played a very important and effective role in the areas of bringing information to the people, raising awareness, education and critiquing the activities of the government and the international community [in Afghanistan], strengthening the process of democratization, analyzing the country's situation and providing entertainment to the population." 287

Reflecting the people's growing trust in the country's independent media, and their frustration with the government, increasing numbers of citizens voice their complaints through the media. Tolo TV reported that at least ten people visit its offices in Kabul "on a daily basis to raise their voices." It added that people did this "to make sure their voices are heard as they fail to do this through government institutions due to some certain problems, including corruption.",288

Touting the government's support for media development in the post-Taliban era, an Afghan vice president, Mohammad Karim Khalili, once went so far as to claim that the growth in the Afghan media sector had played an important role in ensuring what he

\footnotetext{
${ }^{287}$ Faisal Karimi, Media in Afghanistan: Achievements, challenges and responsibilities, Afghanistan Journalists Centre, Kabul, 17 December 2011, http://afjc.af/index.php/11/416-1390-09-26-04-48-25.html, (accessed 20 August 2017)

${ }^{288}$ Gulabduddin Ghubar, People find media last option to raise their voices, Tolo News, 24 November 2017, http://www.tolonews.com/index.php/afghanistan/people-find-media-last-option-raise-their-voices, (accessed 24 November 2017)
} 
called "informational justice." Khalili said this had "allowed the country's entire

population no matter which province they live in to benefit equally" from the media. ${ }^{289}$

\subsection{Safety of journalists}

Afghanistan is certainly one of the most, if not the most, dangerous places to work for journalists. A total of 47 journalists have been killed in the country between 1994 and 2017,45 of them killed since the toppling of the Taliban regime in 2001 . The number of journalists killed in 2017 as of November of that year alone was eight. The Committee to Protect Journalists reports that the motive for 32 of these killings is confirmed to be directly related to the work of the journalists. ${ }^{290}$ These are shocking figures. To put them in perspective, these figures show that greater violence has been inflicted against journalists in Afghanistan than journalists in all next-door neighbouring countries, combined.

The killing of civilian, unarmed journalists, even in a war zone, is one of the most horrifying and despicable acts imaginable. Nevertheless, as far as Afghanistan is concerned, the killing of journalists is not the only type of violence Afghan journalists are exposed to. Other forms of violence against them include physical abuse and intimidation at the hands of government officials, individual strongmen and militia commanders and Taliban insurgents.

\footnotetext{
289 Digital television broadcasting inaugurated in Kabul, Ministry of Communications and Information Technology, Kabul, 1 September 2014, http://mcit.gov.af/fa/news/mcit--opens-digital-tv-broadcasting, (accessed 20 August 2017)

${ }^{290}$ Thirty two journalists killed in Afghanistan, motive confirmed, Committee to Protect Journalists, https://cpj.org/killed/asia/afghanistan/, (accessed 25 August 2017)
} 
Freedom House, in its Freedom of the World 2015 report, said Afghan journalists "face major challenges, including physical attacks and intimidation. Despite a 2007 media law intended to clarify press freedoms and limit government interference, a growing number of journalists have been arrested, threatened, or harassed by politicians, security services, and others in positions of power. ${ }^{291}$

NAI Supporting Open Media, a non-government independent Afghan media support organization that tracks violence against journalists in the country, said "journalists in Afghanistan work under extremely difficult circumstances and routinely face violence, threats, and intimidation that prevent them from carrying out their work."292

NAI tracks incidents of violence against journalists on a daily basis and produces monthly as well as annual reports. Its reporting shows that Taliban insurgents are by far the biggest perpetrators of all types of violence against journalists in the country. For instance, the NAI annual report for 2016 shows a total of 415 cases of violence against journalists. These include 8 murders, 23 physical injuries and 40 cases of verbal abuse against journalists. The data also include a total of nearly 300 cases of what the organization called 'general threats,' including threats by the Taliban after the group temporarily overran cities or towns in different parts of the country. Out of the total, NAI

\footnotetext{
${ }^{291}$ Freedom in the World 2015: Afghanistan, Freedom House, https://freedomhouse.org/report/freedomworld/2015/afghanistan (Accessed 22 August 2017)

${ }^{292}$ Project overview, NAI Supporting Independent Media in Afghanistan, Kabul, http://data.nai.org.af, (accessed 24 August 2017)
} 
attributed 326 of the cases to the Taliban, 63 to the Afghan government and 26 cases to 'unknown men. ${ }^{293}$

The Afghanistan Journalists Safety Committee, an umbrella organization specializing in providing safety support to journalists working in the country, said 2016 "has been the deadliest year for journalists in the history of Afghanistan." However, unlike NAI, AJSC ascribed the blame to "individuals linked with the government for the majority of cases of violence and intimidation." Nevertheless, it also noted that the cases of violence where the Taliban were identified as perpetrators had "dramatically increased" over previous years. The AJSC noted: "The increase in violence and intimidation against journalists by the Taliban and other extremist groups marks a significant shift in the nature of threats and risk against journalists, making the environment more dangerous and lethal."${ }^{294}$

One of the reasons why 2016 was so deadly was because of a Taliban attack against a popular TV channel in Kabul. It was the first such deliberate attack against the country's independent media by the insurgent group. On 19 January 2016, a van carrying journalists from Tolo TV who were returning home at the end of a working day was hit by a Taliban suicide car bomb. The attack resulted in the killing of seven journalists. ${ }^{295}$

\footnotetext{
${ }^{293}$ Instances of journalists' murder, injuries, beaten, detain, insult and threat in 2016 in Afghanistan, NAI Supporting Open Media in Afghanistan, http://nai.org.af/files/documents/mw/Media\%20Watch\%20annual\%20brief\%20report\%202016.pdf, (accessed 24 August 2017)

${ }^{294}$ Six months report (Jan-Jun 2016) 15 years of reporting in Afghanistan, Afghanistan Journalists Safety Committee, Kabul, 11 July 2016, http://ajsc.af/six-months-report-january-june-2016-15-years-of-reportingin-afghanistan-exclusive/, (accessed 24 August 2017)

${ }^{295}$ Seven journalists of Moby media group killed in Taliban attack, BBC Persian, Kabul, 20 January 2017 , http://www.bbc.com/persian/afghanistan/2016/01/160120_fm_kabul_sucide_attack, (accessed 18 August 2017)
} 
The group had previously labelled Tolo TV and one other independent TV channel, 1TV, as "legitimate military targets" because of their reporting on Taliban abuses during the group's brief capture of the northern city of Kunduz in September $2015 .^{296}$

The attack was widely condemned in the country and internationally. NAI Supporting Open Media in Afghanistan called the attack a war crime. In a defiant statement, it said, "Through this criminal and barbaric act, the Taliban have shown that all civilian people are military targets for them." ${ }^{297}$ The Afghanistan Journalists Federation named the day of the attack as “the Dark Wednesday in the History of Afghanistan's Media."298

The United Nations Security Council issued a rare statement condemning the attack, underlining the universal shock the attack against such a soft target had caused. In its statement, the Security Council called the attack "a heinous crime" that had targeted "the right of all Afghans to freedom of expression." 299

\footnotetext{
${ }^{296}$ Frud Bezhan, Taliban declares Afghan TV networks legitimate 'targets,' Radio Free Europe/Radio Liberty, 12 October 2015, https://www.rferl.org/a/taliban-declare-afghan-tv-networks-legitimatetargets/27302358.html, (accessed 20 August 2017)

${ }^{297}$ Attack against Tolo TV workers a war crime that the people of Afghanistan will not forget, NAI Supporting Open Media in Afghanistan, 24 January 2016, http://nai.org.af/dr/-حله-به_كار مندان-تلويزيون_طلوع 2-بك-جناى/, (accessed 18 August 2017)

${ }^{298}$ Afghanistan Journalists Federation names 30 Jadee as black Wednesday in the history of Afghanistan's media, Bakhtar News Agency, Kabul, 20 January 2017, http://bakhtarnews.com.af/dari/social/item/59393فدر اسيون-زور ناليستان-ورسانه_هاى_افغانستان-جهارشنبه-30-جدى-ر ا-جهارشنبه_سياه_درناريخ-رسانه_هاى_افغانستان-نام_كذارىكرد.html, (accessed 20 August 2017)

${ }^{299}$ Security Council press statement on terrorist attack in Kabul, United Nations Security Council, 21 January 2017, https://www.un.org/press/en/2016/sc12215.doc.htm, (accessed 20 August 2017)
} 
The attack had a chilling effect on many journalists, especially those working at Tolo TV and 1TV. Many stopped coming to work. Others were kept away by family members. The editor-in-chief of 1TV spoke of the fear the attack had caused. "Not only are journalists living in fear. Their families are affected as well. My mother is not sleeping and I need to report to my wife every hour for her peace of mind." 300

An Afghan media lawyer based in Kabul painted a bleak picture of safety for Afghan journalists. "There is no safety in Afghanistan for journalists, especially journalists who are living and working in local and remote areas where the Taliban have influence or control, and they do not have any safety or protection," he said. "I don't see any safety for journalists." The lawyer gave an example about the violence journalists faced during the fighting in the northern city of Kunduz in 2015 and 2016 (referenced above). "All media outlets were either burned down or ransacked by the Taliban or damaged by them and the journalists had to flee to Kabul and stayed there and many of them received death threats," he said. "The Taliban did this because they oppose independent media. Even before the Taliban took over Kunduz briefly, they had threatened the local journalists not to report anything from the government or about women or anything related to democracy because they oppose these things." The research participant said the Taliban insurgents had destroyed the premises and equipment of at least seven media outlets in Kunduz. These local outlets, he said, were Roshani TV, Roshani Radio, Zohra Radio, Khawar TV, Khawar Radio, Kaihan Radio and Radio Jaihoon. However, he said all of these media outlets were back and up and running with support from the Afghanistan

\footnotetext{
${ }^{300}$ Helle Wahlberg, What next for media in Afghanistan?, International Media Support, 18 February 2016, https://www.mediasupport.org/next-media-afghanistan/, (accessed 20 July 2017)
} 
Journalists Safety Committee and Internews shortly after government forces retook Kunduz. ${ }^{301}$

The AJSC had managed to help more than 70 journalists through emergency assistance including "providing accommodation, transportation by air and cash handouts to cover emergency expenses for the displace journalists. Female journalists fled under the cover of their burqas." 302

The AJSC annual report for 2016 showed that incidents of violence against journalists were spread out throughout Afghanistan and no part of the country was left unaffected. For instance, of the 54 cases of violence the committee had recorded, four cases had occurred in the country's west, five in the southeast, three in the south, four in the east, eight in the central region, seven in the northeast, three in the north and 20 in Kabul and some northern provinces. ${ }^{303}$

Reflecting this reality, a research participant from the eastern province of Ghazni said "a safe working environment for journalists does not exist at all and this is one of the serious reasons for self-censorship on the part of journalists in this province."304

Another research participant from the Western province of Herat said "no journalist in Afghanistan is safe." The research participant added that there was great disparity in terms of the availability of safety support to journalists in Kabul and in the provinces. ${ }^{305}$

\footnotetext{
${ }^{301}$ Author interview with research participant based in Kabul, 7 May 2017

${ }^{302}$ Helle Wahlberg, What next for media in Afghanistan?, International Media Support, 18 February 2016, https://www.mediasupport.org/next-media-afghanistan/, (accessed 20 July 2017)

${ }^{303}$ Six months report January - June 2016, Afghanistan Journalists Safety Committee, Kabul, page 3, 1 July 2016, http://ajsc.af/wp-content/uploads/2016/07/JAN-JUN2016SixMonthsReportENGLISH.pdf, (accessed 18 August 2017)

${ }^{304}$ Author interview with research participant based in Ghazni, 8 May 2017
} 
A research participant from the eastern province of Nangarhar also said that despite improvement in safety support provided by organizations such as the Afghanistan Journalists Safety Committee, there was need for more work in this area. "The work environment for journalism in Afghanistan is unfortunately dangerous and lethal. The Afghanistan Journalists Safety Committee has made efforts to help journalists but the current situation in the country still has its challenges."306

A research participant who has dealt with issues of safety and protection for journalists in the country said "Afghanistan is one of the most dangerous countries for journalists in the world."

Referring to the steady increase in fighting between government forces and Taliban insurgents since 2014, the research participant said, "with the deterioration of security and escalation of violence, journalists and media outlets could face more violence and intimidation," he said. "The dangers and risks facing media ranges from violent attacks to kidnappings, to threats and intimidation delivered verbally, through threat letters or through digital communication."

According to this research participant, media support organizations such as the Afghanistan Journalists Safety Committee and NAI Supporting Open Media in Afghanistan make an effort to provide various types of safety support to journalists. This ranges from hostile environment training and first aid training to counseling support, legal advice, advocacy to improve the legal environment for journalists' safety,

\footnotetext{
${ }^{305}$ Author interview with research participant based in Herat, 8 May 2017

${ }^{306}$ Author interview with research participant based in Jalalabad, 9 May 2017
} 
emergency support through a 24/7 hotline that AJSC operates and advocacy with the Afghan government and parliament to strengthen safety and protections for Afghan journalists. $^{307}$

A veteran Afghan war reporter said that in a highly unsafe and insecure environment for media such as Afghanistan, the government had a greater responsibility to ensure the safety and security of journalists. The media sector "is not a safe industry or a safe profession for anybody to work at this moment. It has a lot of risks not only from the groups fighting against the government. There are a lot of risks within the country. This will be the biggest problem for the community of journalists in Afghanistan and we might lose more good journalists," he said. "Unfortunately, this industry doesn't have any other sources except to call on the government to help the safety of journalists." ${ }^{308}$

Another research participant, reflecting a similar assessment, said "Afghan journalists are exposed to the highest level of risk at the global level." Therefore, he said the Afghan government "must also pursue cases of violence and murder against journalists seriously with seriousness so that through this approach it can demonstrate its resolve in support of journalists. ${ }^{\text {309 }}$

Another research participant said that the government should provide better security information to media outlets. "Security organizations, particularly the National Directorate of Security needs to work closely with media organizations on delivering

\footnotetext{
307 Author interview with research participant based in Kabul, 8 July 2017

${ }^{308}$ Author interview with research participant based in Kabul, 30 April 2017

${ }^{309}$ Author interview with research participant based in Kabul, 2 May 2017
} 
information regarding threats against media and taking necessary measures to nullify the threats and enhance protection of media outlets." 310

In October 2016, the Afghan government set up a joint safety committee with the Afghanistan Journalists Federation. It is called the Committee for Ensuring the Security of Journalists and Media Outlets. During the committee's inaugural meeting, the country's second vice president, Mohammad Sarwar Danesh, underlined the government's commitment to protecting press freedom and noted the important role of the new committee in the "institutionalization of press freedom." "Freedom of expression is the product of several interconnected principles that form the political and legal foundation of Afghanistan's system and these principles have no use in isolation from one another," Danesh said. "Democracy, pluralism, human rights, equality, social justice and freedom are among the principles upon which is founded the political and legal system of Afghanistan.”

Danesh called the media "the symbol of freedom of expression," adding that "the government is obliged to ensure and protect it." ${ }^{311}$ Subsequently, in January 2017, the joint committee instructed the Independent Directorate of Local Governance, which oversees the appointment of officials to the country's 34 provinces, to establish

\footnotetext{
${ }^{310}$ Author interview with research participant based in Kabul, 8 July 2017

311 Joint committee on the security of journalists and media outlets begins work, Afghanistan Journalists' Centre, 2 October 2016, http://afjc.af/index.php/newsmedia/centeral/kabul/908-2016-10-04-12-55-33.html, (accessed 5 August 2017)
} 
provincial branches of the committee between local officials and journalists in each province. $^{312}$

In reaction to the establishment of this consultation and coordination mechanism, Reporters Without Borders said Afghanistan was "the only country in the world to have created 'committees for the safety of journalists' made up of representatives of the state and journalists' associations." ${ }^{313}$

According to government figures, by September 2017 the committee had identified 172 cases of violence against journalists as "warranting investigation" while 60 cases had been identified as incomplete. These deficient cases were referred to the Afghanistan Journalists Federation for completion. ${ }^{314}$

In September 2016, Danesh led the Afghan government delegation to the annual United Nations General Assembly in New York. In his statement to the General Assembly, Danesh returned to the theme of safety and security for journalists. Danesh said, "currently, more than ten terrorist groups who are sent from outside Afghanistan with the goal of creating obstacles for our state-building efforts and preventing the establishment of peace and stability, are fighting against Afghanistan." He added that "one of (the terrorist groups') main objectives is to suppress democracy, freedom of speech, and our

\footnotetext{
312 Joint committee for coordination on the security of journalists and media outlets chaired by second vice president, Independent Directorate of Local Governance, 25 January 2017, http://idlg.gov.af/fa/news/211030, (accessed 5 August 2017)

${ }^{313}$ Victims of the civil war, Reporters Without Borders, https://rsf.org/en/afghanistan, (accessed 22 July 2017)

${ }^{314}$ Speech of Sarwar Danesh, Second Vice President, at the 90th anniversary of the establishment of Radio Afghanistan and the 40th anniversary of the establishment of Television Afghanistan, Office of the Second Vice President, 21 September 2017, https://vpo.gov.af/18-بيانيه_استاد-سرور-دانش-معاون-دوم-رئيس/, (Accessed 25 September 2017)
} 
free and independent media." In a reference to the high levels of violence against journalists in Afghanistan, Danesh said, "That is why our journalists are subject to serious threats while reporting from the battlefields, and also during terrorist attacks."

Danesh then made an extraordinary request to the United Nations organization. "Afghanistan requests the United Nations to appoint a special representative for the safety of journalists, focused on protecting all journalists, including those serving in Afghanistan. ${ }^{315}$

The United Nations had not appointed such a special envoy as of late 2017. However, Danesh's statement at the largest assembly of governmental leaders in the world showed the sensitivity with which the Afghan government feels it must address the safety and security requirements of the Afghan media sector.

\subsection{Conclusion}

It is clear that the development of Afghanistan's independent media sector represents the creation of an unprecedented platform for information dissemination as well as dialogue at different levels throughout the country. The nascent Afghan media has played a crucial role in educating the public about the importance and technicalities of elections processes. They provide vital information to rural communities. And they act as important pressure

\footnotetext{
${ }^{315}$ Statement by his excellency Sarwar Danesh, Vice President of Islamic Republic of Afghanistan in the 71st session of the UN General Assembly, Office of the Second Vice President of Afghanistan, Kabul, 24 September 2016, https:/vpo.gov.af/en/2016/09/24/statement-by-his-excellency-sarwar-danesh-vicepresident-of-islamic-republic-of-afghanistan-in-the-71th-session-of-the-un-general-assembly/, (accessed 24 August 2017)
} 
valves for citizens frustrated with the government to vent their frustration and complaints peacefully.

At the same time, Afghanistan is clearly a highly dangerous country for journalists to work in. This is tragically illustrated by the high numbers of murders and other types of violence and intimidation involving journalists there. However, the Afghan media sector seems undeterred and remains defiant.

This defiance was clear in the aftermath of the Taliban attack against Tolo TV in 2016. It was also on full display in November 2017 after the Taliban had attacked yet another independent TV channel.

On 7 November 2017, two heavily armed militants attacked the headquarters of Shamshad TV in a brazen, day-time assault. The attackers killed a security guard working for the TV channel before entering the main building where they continued to gun down journalists. At least during part of the attack, the TV channel carried on with its live broadcast. The attackers were finally subdued by local security forces. The final toll was three killed and 21 wounded, most of them journalists working at the channel. The terrorist group ISIS took responsibility for the attack. ${ }^{316}$

Just as in the case of the attack against Tolo TV, this assault was widely condemned. For example, in a statement the head of the Afghanistan Journalists Centre said, "We strongly

\footnotetext{
${ }^{316}$ Three killed, 21 injured in attack on TV station in Kabul, Ariana News, 7 November 2017, https://ariananews.af/three-killed-21-injured-in-attack-on-tv-station-in-kabul/, (accessed 7 November 2017)
} 
condemn the attack; this attack is a brazen assault not just on one TV station but on the entire media [community] and free expression in Afghanistan."317

However, perhaps the most remarkable thing to note about the attack is that the channel was back up and running within hours, even before the smoke had settled and as the injured were being taken to the hospital. The channel's director of news said, "we have all come back [to work], all our journalists and colleagues are back on duty. This is an attack on freedom of media but they cannot silence us. ${ }^{, 318}$

Also, more than a decade and a half after the dawn of a new open era for press freedom in Afghanistan and a debate on turning RTA into a true public broadcaster, RTA remains perceived mainly as a government propaganda mouthpiece. However, the recent statements of the country's political leadership may offer some hope. For example, the admonishment that the RTA management received from the country's vice president in September 2017 could indicate greater future government support to a process that could see the birth of a well-regarded, popular, credible public broadcaster for the first time in the country. Given its presence in each of the country's 34 provinces, RTA remains the only truly national broadcaster that has the potential to transform into a true public service broadcaster in the years to come covering the entire country.

The chapter also identified the need for the Afghan media sector as a whole to improve diversity within their ranks through better hiring practices.

\footnotetext{
${ }^{317}$ Gunmen storm TV station in Kabul, Afghanistan Journalists Centre, 7 November 2017 , http://afjc.af/english/index.php/af-media-news/central-provinces/kabul/636-gunmen-storm-tv-stationkabul.html, (accessed 7 November 2017)

${ }^{318}$ Afghan television channel Shamshad TV back on air after attack, BBC News, 7 November 2017, http://www.bbc.com/news/world-asia-41898011, (accessed 7 November)
} 
Finally, the chapter also showed a high degree of public trust and confidence in the media. This reflects a consensus about the role the media has played in connecting Afghans to each other and about its function as a platform for democratic discourse. As a research participant put it, despite high levels of violence and other major problems in the country including poverty and government corruption, Afghan media at least help people stay informed. "To be honest, it's the media that helps a lot of Afghans to bear the difficult conflicts, especially in the past four or five years," he said. "The concept of people being aware of what's happening in their country helps people. So I believe media development has been a success of the past 16 years."319

\footnotetext{
${ }^{319}$ Author interview with research participant in Kabul, 30 April 2017
} 


\section{Chapter: PROFESSIONAL CAPACITY BUILDING AND SUPPORTING INSTITUTIONS}

This chapter will review and assess the Afghan news media in light of Category 4 of the UN's Media Development Indicators: Professional capacity building and supporting institutions that underpin freedom of expression, pluralism and diversity. It will survey the availability and diversity of professional media training in Afghanistan. As such, it will look at the professional training programs offered at the university level (both public and private) as well as other types of capacity building programs conducted by nongovernment organizations and media outlets themselves. The chapter will assess Afghan journalists' ease of access to training and capacity building programs they deem necessary for their work not only in the capital and other big cities. It will also look at the situation out in the provinces where it can reasonably be assumed that training and capacity building resources and opportunities would be more limited. The chapter will explore the question of whether or not media trade unions and professional associations play any significant role in journalism capacity building. Critically, the chapter will study whether or not the training and capacity building programs available in Afghanistan promote democracy and values such as pluralism and diversity.

\subsection{Availability of professional media training}

A 2010 report on the state of Afghan media noted that "Afghanistan is one of the most trained countries as far as media is concerned." The report added that "training opportunities for media outlets in Afghanistan abound." It noteed that various Afghan 
and international organizations such as NAI Supporting Open Media, Mediothek, the Institute for War and Peace Reporting (IWPR), Equal Access, International Media Support, Media Support Systems (MSS), International Foundation for Electoral Systems (IFES) and others are active in this field. It further noted that training courses include “anything from principles of journalism to peace and war reporting, investigative journalism, safety training, election reporting, media law training and video journalism. ${ }^{320}$ In other words, it is reasonable to say that the Afghan media sector does not suffer from a shortage of media training programs and courses.

A research participant said it was easy for most journalists in Afghanistan to access training opportunities, especially in the bigger cities such as Kabul. "Many amateur journalists who started after 2001 found opportunities to study, many got scholarships around the world and became more professional," he said. Because of the growing institutionalization of the media industry, "the focus of training is more on-the-job training and experience. The industry is big now. A lot of young people who graduate from journalism schools, they can go and work in a TV or radio station and learn on the job.",321

Another research participant said training and capacity building courses offered by NGOs played a critical role in the early years following the collapse of the Taliban regime. “Back in 2003 and 2004, many journalists didn't know how to use a computer or write a

\footnotetext{
${ }^{320}$ Afghan Media in 2010: A Synthesis Report, Altai Consulting, page 45, http://www.altaiconsulting.com/wp-content/uploads/2016/03/Afghan-Media-in-2010.pdf, (accessed 8 July 2017)

${ }^{321}$ Author interview with research participant in Kabul, 30 April 2017
} 
report. NGOs started working in this area, and many journalists went through short and long courses and enhanced their skills," he said. "This is mainly how the journalists got their training." This research participant also pointed to an important transition that has taken place in recent years in terms of journalism education and training in Afghanistan. He said training programs, including both theoretical and practical elements, are today increasingly provided by Afghan institutions and media organizations.

The research participant gave the example of NAI Supporting Open Media. NAI provides free short-term courses to young journalists who have access to its on-site radio and TV studios for training. In addition, NAI established a private Media Training Institute in 2012 where it offers both short courses and a two-year diploma program. ${ }^{322}$ The short courses cover topics such as journalism essentials, radio journalism, video journalism essentials, radio package production and investigative journalism. ${ }^{323}$ On the other hand, the two-year diploma course includes a much more comprehensive set of topics. These range from presentation skills, operating and editing, broadcast laws, regulations and compliance, production, reporting and interviewing to copywriting, sales, programming, multimedia and online broadcast skills, marketing and management and business skills. The program also includes practical broadcast courses and a final internship. ${ }^{324}$

NAI also provides training to Afghan journalists in the provinces outside Kabul. For example, according to the United Nations Assistance Mission in Afghanistan, NAI

\footnotetext{
${ }^{322}$ Author interview with research participant in Kabul, 7 May 2017

${ }^{323}$ Nai Media Institute, Short courses, http://nmi.edu.af/short-courses, (accessed 23 November 2017)

${ }^{324}$ Nai Media Institute, Diploma in Media, http://nmi.edu.af/diploma-media, (accessed 23 November 2017)
} 
provided 54 training programs in the country. An example the UN cited in 2011 was the training of some 50 reporters from the state-owned media outlets in the eastern province of Nangarhar that was sponsored by the UN and conducted by NAI trainers. A UN officer at the time said the training "improves access to information and promotes the status of journalists in Afghanistan. ${ }^{, 325}$

A research participant in the southern city of Kandahar said access and availability of training opportunities and resources for journalists there was good. "The system of professional training for journalists is effective here," he said. "As a result, a greater number of journalists is now professional. The role of nongovernment organizations has been key. ${ }^{, 326}$ He said media support organizations and professional associations had organized numerous "training, professional capacity building programs, workshops and seminars which have improved from day to day" in Kandahar. The research participant referred to the Afghanistan Journalists Safety Committee as an example of nongovernment organizations that have made a difference in professional media capacity building and training in the south of the country. The committee mainly provides safety trainings but it also offers training programs in first aid, photojournalism, media law, ethics of journalism, conflict sensitive reporting, etc. ${ }^{327}$

\footnotetext{
${ }^{325}$ Afghanistan media training fosters freedom of expression, United Nations Assistance Mission for Afghanistan (UNAMA), 12 January 2011, https:/unama.unmissions.org/afghan-media-training-fostersfreedom-expression, (accessed 24 November 2017)

${ }^{326}$ Author interview with research participant in Kandahar, 9 May 2017

${ }^{327}$ Afghanistan Journalists Safety Committee, Training, http://ajsc.af/advocating-media-rights/, (accessed 30 October 2017)
} 
Another research participant in Nangarhar province said at least three organizations (IWPR, NAI and AJSC) provided training programs there. The research participant said some foreign embassies also organize occasional training programs for local journalists. ${ }^{328}$

A research participant in the western province of Herat said there was easy access to the many training programs that are regularly offered to journalists there. The research participant said journalist trainees also had good access to reporting equipment during training, especially where NAI conducted the trainings. ${ }^{329}$

As pointed out in the previous chapter, much of the funding for the media sector in Afghanistan over the past 15 years has come from foreign assistance budgets. Apart from the establishment of private universties and other training institutions, such as the NAI Media Institute, much of the funding for media training programs also comes from international donor sources. A research participant said Afghan media outlets themselves must start to allocate more financial resources to capacity building and training programs for their journalists, similar to media outlets in other countries. "In Afghanistan, all the training has been free training because there was international aid and international support. Now that this aid is reducing, media outlets should invest their own resources," he said. "Also, if there is competition in the market, then you should be able to provide

\footnotetext{
${ }^{328}$ Author interview with research participant in Jalalabad, 8 May 2017

${ }^{329}$ Author interview with research participant in Herat, 8 May 2017
} 
good products. And who will provide good media products? Of course, the journalists. So, the outlets should invest more in this area." 330

Another research participant said although international funding for training and capacity building programs has declined in recent years, "internships offered by private media to students have increased substantially." 331

Over the past several years, NGOs such as IWPR and Mediothek, a German-funded Afghan media support organization based in Kabul, have established media hubs across the country. These hubs provide safe working spaces for journalists where they can access basic reporting and, in some areas, editing equipment as well as internet connections so they can send out their reports from the field. A study conducted in 2010 showed that IWPR had established such facilities in Helmand, Herat and Mazar-e-Sharif cities whereas Mediothek has set up similar hubs in Kunduz, Jalalabad, Khost, Kabul, Peshawar and Mazar-e-Sharif. The study noted that "these hubs represent an innovative initiative in places like Helmand, where there used to be no alternative voice to those of international journalists embedded in the military. ${ }^{, 332}$

In addition to providing training and support to journalists in Afghanistan, Mediothek aims to foster closer people-to-people ties between Afghanistan and Pakistan across the

\footnotetext{
${ }^{330}$ Author interview with research participant in Kabul, 7 May 2017

${ }_{331}^{33}$ Author interview with research participant in Kabul, 18 May 2017

${ }^{332}$ Afghan Media in 2010: A Synthesis Report, Altai Consulting, page 32, http://www.altaiconsulting.com/wp-content/uploads/2016/03/Afghan-Media-in-2010.pdf, (accessed 8 July 2017)
} 
Durand Line. The Durand Line, named after a British colonial official, was drawn in 1893 that separated certain parts of Afghanistan from the mainland and which Pakistan has claimed as its official border with Afghanistan since its emergence as an independent country during the partition of the Indian subcontinent in 1947. The matter is still disputed between the two countries. The organization says it "encourages the people in both sides of the Durand Line to come together by sharing ideas, experiences and journalistic writings with each other. ${ }^{, 333}$ For example, Mediothek conducted more than 40 training sessions between January 2009 and February 2014 for Afghan journalists on topics ranging from journalism ethics, media and rule of law, and peace journalism to video editing, effective report writing, feature writing, documentary film editing and election reporting. ${ }^{334}$

A research participant said journalism training must go beyond the teaching of basic journalism skills where Afghanistan has already made significant gains. Instead, he argued the focus should move more towards investigative journalism and the teaching of better technological and cyber skills. The research participant argued this would allow journalists to report on complex issues and dig deeper into areas of public interest and concern. "We should focus more on investigative reporting. This doesn't mean we should just focus on government corruption and insecurity," he said. "I would be interested to know, for example, how much is the education budget for a province in Afghanistan, how many students there are, how many toilets are available for girl students, how many for

\footnotetext{
${ }^{333}$ Media houses, Mediothek, Afghanistan, http://mediothek-afghanistan.org/MediaHouses.html, (accessed 8 December 2017)

${ }^{334}$ Capacity building, Mediothek Afghanistan, http://mediothekafghanistan.org/?q=en/CapacityBuilding.html, (accessed 8 December 2017)
} 
boys, to find out how many teachers there are and what their level of education is, how many hours each teacher works. This kind of investigative reporting will improve our education system and government policy., ${ }^{335}$

\subsection{Availability of academic courses in media practice}

Given the phenomenal growth in the media sector in Afghanistan, interest among young students in journalism studies across the country has spiked over the past years. Until 2001, the Faculty of Journalism at Kabul University was the only university program that granted bachelor degrees in journalism. Established in 1961, the faculty offers undergraduate degrees through its two departments, namely Press Department, and Radio and Television Department. The faculty currently has a library, radio, TV, computer and photojournalism labs. The journalism discipline is currently one of the most popular at Kabul University, on par with medicine, engineering, law and economics. Because of high interest among both male and female students, the faculty emphasizes gender balance in accepting new students. ${ }^{336}$ As of 2017 , there were 650 journalism students at Kabul University. ${ }^{337}$ Also as of 2017, no university offered Master's or PhD level journalism degrees in the country.

\footnotetext{
${ }^{335}$ Author interview with research participant in Kabul, 7 May 2017

${ }^{336}$ Short history of the Journalism Faculty at Kabul University, Kabul University, Kabul, http://ku.edu.af/fa/page/social-science/880/history, (accessed 12 December 2017)

${ }^{337}$ Current state and achievements of the Faculty of Journalism, Kabul University, Kabul, http://ku.edu.af/fa/page/social-science/880/current-situation, (accessed 12 December 2017)
} 
As of the academic year 2017, there were at least ten government universities across Afghanistan that offered degrees in journalism. As shown in Table 7 below, these universities together admitted a total of 1689 students in the 2017 academic year alone through the annual university entrance exam called kankor. ${ }^{338}$

Table 7: Total number of students enrolled in journalism programs in Afghanistan in 2017

\begin{tabular}{|l|l|l|}
\hline No. & Name of university & $\begin{array}{l}\text { Number of students } \\
\text { admitted }\end{array}$ \\
\hline 1 & Kabul University & 200 \\
\hline 2 & Herat University & 150 \\
\hline 3 & Balkh University & 201 \\
\hline 4 & Nangarhar University & 150 \\
\hline 5 & Alberoni University & 150 \\
\hline 6 & Kandahar University & 150 \\
\hline 7 & Baghlan University & 150 \\
\hline 8 & Jawzjan University & 60 \\
\hline 9 & Khost Sheikh Zayed University & 150 \\
\hline 10 & Parwan University & 119 \\
\hline & TOTAL & 1689 \\
\hline
\end{tabular}

At the same time, of the 139 private universities and institutions of higher learning registered with the Ministry of Higher Education of Afghanistan, at least 11 offer

\footnotetext{
${ }^{338}$ Konkor results for all of Afghanistan by discipline in 1396 (2017), Kankor Exam, Afghanistan, https://konkor.ooyta.com/?pg=1395\&res=1\&lang=fa\&lang=fa, (accessed 12 December 2017)
} 
journalism programs. ${ }^{339}$ Private universities do not take their students through the annual kankor university entrance exam. Private universities generally do not provide their enrollment numbers. However, given that the number of journalism programs offered at private universities are similar to those offered by state universities, it is reasonable to assume that the number of students who study journalism at private universities would be equivalent, too. These are indeed impressive numbers, especially for a country where independent journalism was banned and only one or two journalism programs existed until a mere 15 years ago.

The main reason for the high level of interest in journalism, especially among Afghan youth, flows from the phenomenal growth in the media sector following the fall of the Taliban regime in 2001. The entry of large numbers of young Afghans into the media sector was in significant part facilitated by the infusion of substantial international donor funding into the creation of media outlets and media training programs.

Many young journalists are also motivated by a sense of service, and feel they can help give the downtrodden and underprivileged in society a platform to have a voice. ${ }^{340}$

Research participants uniformly celebrated this growth in the availability and accessibility of academic journalism programs. For example, a research participant said

\footnotetext{
${ }^{339}$ Universities and institutions of higher learning, Ministry of Higher Education, Afghanistan, https://mohe.gov.af/prs/universities, (accessed 12 December 2017)

${ }^{340}$ The motivation for more women in journalism, Pajhwok Afghan News, 11 September 2017, https:/www.pajhwok.com/en/2017/09/11/motivation-more-women-journalism, (accessed 17 February 2018), and Lina Rozbeh Haidari - VOA Ashna TV anchor on state of journalism and digital media in Afghanistan, 17 September 2013, http://www.bitlanders.com/blogs/lina-rozbeh-haidari-voa-ashna-tvanchor-on-state-of-journalism-and-digital-media-in-afghanistan/71483, (accessed 17 February 2018)
} 
the increase in the number of degree programs had opened opportunities for more comprehensive journalism education. "We used to have some NGOs working on quick training programs for young people to become photographers and videographers," he said. "Now university programs are more focused on actual journalism training and education." 341

However, some were quick to point out the continuing low quality of education materials, especially at private universities.

A research participant in Kabul said government universities still maintained a certain "credibility" in the eyes of the public. "Government universities, through some changes they have introduced in recent years, have been able to train good journalists through academic programs," he said. "Private universities, on the other hand, have been slower in this area and have not been able to introduce good talent to society in this field." This research participant also said that similar to training provided by nongovernment organizations, most university programs also impart "basic reporting skills." When it comes to advanced skills and education, he said, "most senior journalists try to attend journalism courses outside the country.",342

Another research participant agreed that more work is required to improve journalism education quality across the board in the country. "In general, the quality of education in the field of journalism is poor in Afghanistan," he said. "Therefore, media has not

\footnotetext{
${ }^{341}$ Author interview with research participant in Kabul, 30 April 2017

${ }^{342}$ Author interview with research participant in Kabul, 2 May 2017
} 
acquired the expected amount of professional development and maturity in the past fifteen years." ${ }^{343}$ Another participant said even the majority of graduates from university programs lack many of the necessary skills for high quality journalism. However, this participant, similar to a few others, was quick to add that the growing tradition of internships offers a rapid path to the acquisition of more practical skills. ${ }^{344}$

One of the main reasons for the prevailing weakness in the academic training of journalism in Afghanistan is the absence of sufficient high quality teaching staff. For example, of the 22 teachers at the Journalism Faculty at Kabul University, only one holds a $\mathrm{PhD}$ while eight have master's degrees and all the remaining 13 - the majority - only hold BA degrees. However, since 2011, every year the faculty sends five of its instructors to Nebraska University in the United States to build their English language skills and teaching methods. ${ }^{345}$ The absence of highly educated faculty is even more dire in the provinces outside Kabul. For instance, of the 13 faculty members at Herat University journalism faculty, only five hold master's degrees while the remaining nine have BA degrees. $^{346}$

The situation at private universities is not any better. Indeed, in many cases, it's worse. For instance, Kardan University, the first and largest private university in the country which offers an undergraduate degree in journalism, only has three faculty members on

\footnotetext{
${ }^{343}$ Author interview with research participant in Kabul, 8 July 2017

${ }^{344}$ Author interview with research participant in Ghazni, 8 May 2017

${ }^{345}$ Current situation of Journalism Faculty, Kabul University, http://ku.edu.af/en/page/socialscience/880/current-situation, (accessed 12 December 2017)

${ }^{346}$ Introduction of Faculty of Journalism and Communication, Herat University, https://hu.edu.af/en/journalism, (accessed 12 December 2017)
} 
its teaching staff. One of these three holds a medical degree from Kabul University but has worked as a journalist for many years. The other two are graduates of the journalism program at Kabul University. ${ }^{347}$

\subsection{Conclusion}

The chapter findings make it clear that Afghanistan truly is one of the most saturated countries when it comes to journalism training and education. The research discovered three categories of major players in the field of journalism training and education: 1) government universities, 2) private universities and other institutions of higher learning that have emerged in the last decade, and 3) NGOs and media support organizations. The research showed that the decrease in international funding for the media sector (discussed further in Chapter 7) has not affected media training and education. The job has shifted to local organizations such as NAI, AJSC and others while media outlets themselves increasingly provide opportunities for internship and practical training. Above all, this chapter showed the enduring high level of interest among young Afghans for journalism in the country.

\footnotetext{
${ }^{347}$ Curriculum vitae of instructors, Journalism Department, Kardan University, http://www.kardan.edu.af/data/uploads/files/ختصر -سو انح-استادان.pdf, (accessed 12 December 2017)
} 


\section{Chapter: INFRASTRUCTURAL CAPACITY}

This chapter will review and assess the Afghan news media in light of Category 5 of the UN's Media Development Indicators: Infrastructural capacity is sufficient to support independent and pluralistic media. The chapter will study the state of infrastructure capacity in the Afghan media sector, focusing particularly on its growth and development since the fall of the Taliban regime. The chapter will look at the availability of modern and effective infrastructure for print, radio and TV broadcasting throughout the country. As part of that, it will examine the level of access to information and communication technology, especially among marginalized groups such as people living in rural areas and women. The chapter will survey the level of Information and Communication Technology (ICT) penetration in the country. It will also look at the growth in the use of social media platforms.

\subsection{Availability of technical resources for the media}

Media organizations have access to modern technical facilities for news gathering, production and distribution

Between 1992 when the Mujahideen took over power and 2001 when the Taliban regime was toppled, there was no investment in media or ICT infrastructure in Afghanistan. The country suffered in painful isolation from the rest of the world. There was also no upgrading to telecommunications and radio and TV technology that mostly dated back to 
the 1970 s. ${ }^{348}$ However, in 2001 the country all of a sudden jumped right into $21^{\text {st }}$ century technology. As a research participant described it, "fifteen years ago, we started with the latest technology, more advanced than our neighours because they still had old technologies. Our radio and TV stations have the latest technology for production, broadcasting, editing, etc."349

A 2014 report on the media sector in Afghanistan said, "The media sector has dramatically changed in the past decade, and is likely to change further still in the subsequent one. The development of the country, and better access to infrastructure and resources give increasing number of Afghans access to a much more complex offer, while new technology can lower barriers to entry in the sector for small actors." 350

A research participant in Nangarhar said ten years ago he and many journalists in the province didn't even have access to basic equipment such as voice recorders or editing equipment. Today, he said, "in terms of technical equipment and technology, we have witnessed very good progress." 351

In terms of TV infrastructure, most private stations today operate out of their own buildings. For example, Tolo TV, the largest private TV network, operates out of a series

\footnotetext{
${ }^{348}$ Information and communication sector strategy, Afghanistan Telecommunications Regulatory Authority, page 11, http://atra.gov.af/Content/files/ICT\%20Sector\%20Strategy-English.pdf, (accessed 20 July 2017)

349 Author interview with research participant in Kabul, 7 May 2017

${ }^{350}$ Afghanistan Media in 2014: Understanding the Audience, Altai Consulting, February 2015, page 36, http://www.altaiconsulting.com/wp-content/uploads/2016/05/Altai-Internews-Afghan-Media-in-2014.pdf, (accessed 7 July 2017)

${ }^{351}$ Author interview with research participant in Nangarhar, 9 May 2017
} 
of at least three studios in the heart of the diplomatic enclave in Kabul city. ${ }^{352}$ More than 100 reporters, producers and managers work in these studios and adjacent offices. ${ }^{353}$ This team manages the sometime simultaneous broadcast of several programs on Tolo's three main channels, i.e. Tolo TV, ToloNews (a 24-hour news channel) and Lemar TV. Tolo TV currently has the technical capacity to broadcast free-to-air services to viewers in 14 cities in Afghanistan and has plans "to continually expand our reach within Afghanistan.” ${ }^{, 354}$ Moby Group, which owns Tolo TV, ToloNews, Lemar TV and Arman FM, is the only Afghan media group that has expanded into the Middle East and North Africa regions. $^{355}$

Tolo also runs the popular Arman FM radio station and a major production company out of the same premises.

Another popular private TV station, 1TV, also has its own facilities a few streets down the road from Tolo TV in the centre of Kabul city, a stone's throw from the presidential palace. According to the station, it is "equipped with world class high-end digital broadcast equipment... 1TV has over 325 square meters world class studios, modern lighting systems, video switchers, and video recognition capabilities, Sony video cameras, video editing stations, comprehensive dubbing systems and digital audio studios."356

\footnotetext{
${ }^{352}$ Author's observations from personal visits to the various Tolo studios over the years since at least 2010

353 About us, Tolonews.com, http://www.tolonews.com/about-us, (accessed 14 December 2017)

${ }^{354}$ About us, Tolo.tv, http://www.tolo.tv, (accessed 14 December 2017)

${ }^{355}$ Ken Auletta, Afghanistan's first media mogul, The New Yorker, 5 July 2010, https://www.newyorker.com/magazine/2010/07/05/the-networker-2, (accessed 20 October 2017)

${ }^{356}$ About us, 1TV, http://www.1tv.af/en/about-us, (accessed 14 December 2017)
} 
Similar to Tolo TV and its affiliates, and 1TV, virtually all TV stations in Kabul have their own buildings, studios and high-quality equipment. ${ }^{357}$

The state of radio infrastructure and technical resources is on par with, if not better than, what the TV stations have. As noted below, this is mainly because radio equipment and technical resources is more affordable and its operation requires much less space and physical infrastructure than TV stations.

Online:

As seen in the numbers in Table 2 below, internet access has expanded significantly in Afghanistan over the past several years. This has allowed for the blossoming of online media platforms. In addition to a plethora of academic, information and entertainment platforms, countless news websites have also sprung up.

For example, all major media outlets, including Tolo TV, 1TV, Hasht e Subh daily, Mandegar Daily and others, have established their own websites where they often post their entire content free of charge. Most TV stations also upload their programs on Facebook and YouTube, which are among popular online and social media platforms in the country.

As in most other countries, social media has grown quickly in Afghanistan. Today, around 9 percent of the slightly more than 10 percent of the country's population that is connected to the internet are also social media users. An October 2017 study by Altai

\footnotetext{
${ }^{357}$ Based on author observations during visits to the offices and studios of most TV stations based in Kabul between 2011-2014 when he was spokesperson at the Ministry of Foreign Affairs of Afghanistan
} 
Consulting showed that 80 percent of social media users were between 18 and 30 years of age, proving the medium's popularity with the youth. According to the report, most social media users prefer Facebook. The report also noted that "media organizations have invested in social media enthusiastically as a new platform for their content, dominating the pages found online along with government, politics and elections related pages." This nascent sector is still largely unregulated. ${ }^{358}$

In addition to the internet as a wide open source for information, the Afghanistan Centre at Kabul University (ACKU) is the largest online resource centre for both archival and up-to-date academic information as well as other materials. For instance, ACKU holds the largest collection of Afghan newspapers going back decades, which form a part of its 150,000 documents, which include monographs, posters, newspapers, slides, CDs, periodicals and magazines in Dari, Pashto, English and other foreign languages. ${ }^{359}$

At the same time, more than a dozen Afghan government universities today, for example, are connected via internet with each other and with partner universities abroad, mainly in Europe. Supported by the US government and NATO, this allows thousands of students to access valuable research materials and virtually collaborate with foreign scholars and students. ${ }^{360}$

\footnotetext{
${ }^{358}$ Social media in Afghanistan: Users and engagement, Altai Consulting for Internews Afghanistan, October 2017, pages 7-8, Altaiconsulting.com, https://www.internews.org/sites/default/files/201712/Internews_Afghanistan_SocialMediaAssessment_Altai_2017-12.PDF, (accessed 22 December 2017)

${ }^{359}$ About us, Afghanistan Centre at Kabul University, Kabul University, http://acku.edu.af/about-us/, (accessed 21 July 2017)

${ }^{360}$ Afghanistan's universities accelerate on the virtual Silk Road, Geant Project, 5 December 2013, https://geant3plus.archive.geant.net/MediaCentreEvents/news/Pages/Virtual_Silk_Road.aspx, (accessed 20 September 2017)
} 
The country's election commission even developed a website during the 2014 presidential elections that guided voters to their nearest polling stations. ${ }^{361}$

A research participant said foreign assistance had been critical to the establishment of modern media infrastructure in the country. Because of the investments made over the years, "right now, most media outlets have access to new technology and their use of technology and professional expertise in its use has improved significantly." However, he pointed out that continued expansion and upgrading of the infrastructural and technological foundation of the media sector would suffer unless international assistance continued in the coming years. "Investing in the use of technology in the media sector is not high on the agenda for the Afghan government or even media outlets because such investments require a lot of capital and Afghan media outlets cannot afford to make such investments." 362

Another research participant said the investments in infrastructure and equipment since 2002 had allowed many TV channels to produce a diverse set of high quality programs. "Look at the soap operas that now each media outlet is producing or dubbing and subtitling foreign ones. Also, recently we had live broadcast of football matches that were done using drone cameras. What we have now isn't even comparable to what we didn't have 15 years ago," he said. "Some of the media outlets are well-equipped so you can

\footnotetext{
${ }^{361}$ http://www.votehere.af/\#/manual-map, Independent Election Commission of Afghanistan, (accessed 20 December 2017)

362 Author interview with research participant in Kabul, 2 May 2017
} 
have live broadcasts on a daily basis on many of our TV stations which was simply not possible even a few years ago. Also, a lot of our photographers are using professional cameras and the content they produce is used internationally." ${ }^{363}$ Indeed, many Afghan journalists have won international prizes and awards in the past years, including the country's first Pulitzer Prize which was awarded to photographer Massoud Hossaini in $2012 .^{364}$

Similar to other areas, much of the support for technical and infrastructural facilities for Afghan media came from international aid budgets and NGO funds. For example, very early in the post-Taliban period, USAID provided core funding of $\$ 228,000$ for the building of infrastructure for Arman FM radio station in 2003 and \$2.5 million for transmitters and infrastructure for Tolo TV in 2004, respectively. ${ }^{365}$ As shown in chapter 5, both Arman FM and Tolo TV today rank among the most popular media outlets in the country. In total, USAID spent an estimated \$150 million on media development in Afghanistan between 2002 and 2011. ${ }^{366}$ In addition, the agency funded a 3-year $\$ 32$ million project between 2010 and 2013 through Internews. ${ }^{367}$

\footnotetext{
${ }^{363}$ Author interview with research participant in kabul, 30 April 2017

${ }^{364}$ The 2012 Pulitzer Prize winner: Massoud Hossaini, Time.com, 17 April 2012, http://time.com/42536/the-2012-pulitzer-prize-winner-massoud-hossaini/, (accessed 14 December 2017) ${ }_{365}$ Afghan Media in 2010: A Synthesis Report, Altai Consulting, page 29, http://www.altaiconsulting.com/wp-content/uploads/2016/03/Afghan-Media-in-2010.pdf, (accessed 8 July 2017)

${ }^{366}$ Thanassis Cambanis, Foreign aid sustains fragile Afghan media, thanassiscambanis.com, 25 February 2011, http://thanassiscambanis.com/sipa/?p=150, (accessed 14 December 2017)

${ }^{367}$ USAID's Afghanistan media development and empowerment project: audit of costs incurred by Internews network, Special Inspector General for Afghanistan Reconstruction, June 2015, https://www.sigar.mil/pdf/audits/Financial_Audits/SIGAR-15-64-FA.pdf, page 2, (accessed 14 December 2017)
} 
Support to the network of more than 40 community/local radio stations that Internews helped set up (see chapter 5) also included "technical advice, broadcast and production studio equipment, portable field recorders and microphones, a 150-watt FM transmitter, a 30-meter tower and a generator to power the station during power outages."368

As highlighted in detail in Chapter 5, in addition to the emergence of hundreds of media outlets in the past fifteen years, infrastructure support has included the establishment of private news agencies such as Pajhwok Afghan News (the country’s largest news agency overall), press distribution networks (such as Nye Express), radio distribution networks (such Salam Watandar) and journalist associations. ${ }^{369}$

In addition to the US government, the largest donor to Afghanistan since 2001, other countries have also provided significant assistance to the Afghan media sector, with mixed results.

For instance, according to an Organization for Economic Cooperation and Development (OECD), the Canadian government, through the Canadian International Development Agency, spent C\$1.6 million of a total budget allocation of C\$2.1 million in 2004/05 and 2005/06 "to increase the technical capacity and journalistic skills of women and support the development of women's media, using community radio." The report stated that the

\footnotetext{
${ }^{368}$ Jean Fairbairn, Community media sustainability guide: The business of changing lives, Internews, 2009, page 67, http://www.amarc.org/documents/manuals/InternewsCommunityMediaGuide2009.pdf, (accessed 25 July 2017)

${ }^{369}$ Afghan Media in 2010: A Synthesis Report, Altai Consulting, page 30, http://www.altaiconsulting.com/wp-content/uploads/2016/03/Afghan-Media-in-2010.pdf, (accessed 8 July 2017)
} 
implementing organization "failed to provide adequate and appropriate capacity building in planning, technical assistance and training so that these stations could become financially and managerially self-sustainable, and legally constituted under Afghanistan law." The report further noted that only 56 percent of the expected outcomes were actually achieved, including the production of radio programs and the setting up of four radio stations and one newspaper. ${ }^{370}$

To put the above assistance numbers in perspective, the total international aid expenditure in Afghanistan between 2001 and 2010 amounted to a total of $\$ 35$ billion, meaning that the media sector has received modest levels of assistance. ${ }^{371}$

In terms of physical infrastructure, in addition to major media outlets that have established their own robust facilities and offices, smaller media outlets, especially in the provinces, have access to media houses and centers established by media organizations such as Mediothek and IWPR (see Chapter 6).

International development assistance has also gone into the development of infrastructure in the state media sector. For example, USAID provided support to the establishment of a Government Media and Information Centre (GMIC) in Kabul in 2007. Created to "respond to the great information need of the Afghan public, media and other national

\footnotetext{
${ }^{370}$ Review of the Afghanistan program: final version, Organization for Economic Cooperation and Development, May 2007, pages 39-40, http://www.oecd.org/countries/afghanistan/39591223.pdf, (accessed 14 August 2017)

${ }^{371}$ Monitoring the principles of good international engagement in fragile states and situations: country report 1: Islamic Republic of Afghanistan, Organization for Economic Cooperation and Development, 2010, page 3, http://www.oecd.org/countries/afghanistan/44654918.pdf, (accessed 14 August 2017)
} 
and international stakeholders," the centre offers the use of a high-tech, spacious conference hall to journalists as well as its media resource centre. The resource centre is equipped with high-speed internet, books and a digital library that journalists, students and government communications officers can use. The centre also allows access to its modern production studio, which is mainly used for storing recordings of the regular, almost daily, press conferences held there by various government departments. ${ }^{372}$

In addition to the main GMIC in Kabul, provincial media and information centres, called Anaar Multimedia Centres, have also been established in key regional hubs, also with support from USAID. ${ }^{373}$ For example, the Kandahar media and information centre was set up in 2010 with financial support from the Canadian government ${ }^{374}$, whereas similar centres were set up in Mazar-e-Sharif ${ }^{375}$ in the north and Herat ${ }^{376}$ in the west of the country in 2013, also with international financial support. These media centres play important roles in supporting the work of Afghan journalists, especially in the provinces, offering internet access and equipment and facilities. They're also handicap accessible and provide new media training for men and women. ${ }^{377}$ The Centre for the Protection of

\footnotetext{
${ }^{372}$ About us, Government Media and Information Centre, http://www.gmic.gov.af/dari/gmic, (accessed 20 August 2017)

${ }^{373}$ Factsheet, Anaar multimedia centres, United States Agency for International Development, December 2012, https://www.usaid.gov/sites/default/files/documents/1871/Fact\%20Sheet\%20AMCs-AMDEP\%20\%20Dec\%202012\%20-\%20FINAL.pdf, (accessed 13 December 2017)

${ }^{374}$ Government media centre established in Kandahar, Radio Azadi, 14 October 2010, https://da.azadiradio.com/a/2190074.html, (accessed 20 November 2017)

${ }^{375}$ Government media and information centre inaugurated in Balkh, 12 December 2013, Frasi.ru, http://www.farsi.ru/doc/8073.html, (accessed 20 November 2017)

${ }^{376}$ Government media centre in Herat begins work, 18 December 2013, Shafaqna.com,

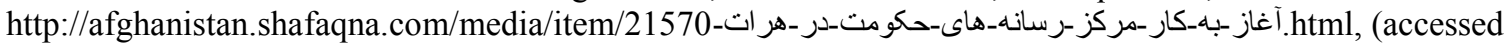
20 November 2017)

${ }^{377}$ Factsheet, Anaar multimedia centres, United States Agency for International Development, December 2012, https://www.usaid.gov/sites/default/files/documents/1871/Fact\%20Sheet\%20AMCs-AMDEP\%20\%20Dec\%202012\%20-\%20FINAL.pdf, (accessed 13 December 2017)
} 
Afghan Women Journalists, siting working women journalists, said in 2017 that facilities dedicated to women journalists in such centres enhance "the interest and presence of female journalists" in the country. ${ }^{378}$

Also, Radio Television Afghanistan, almost totally destroyed during the civil war and Taliban regime years (1992-2001) received a significant infusion of \$26.5 million in Japanese assistance between 2002 and 2003. The assistance specifically included broadcasting equipment and improvement of broadcasting facilities. ${ }^{379}$

Today, with its presence in all of the country's 34 provinces, RTA boasts the widest coverage network in the country. For example, the RTA station in Bamyan, one of the least developed and remotest provinces in the mountains of central Afghanistan, has its own building, radio and TV transmitters, two digital TV cameras and four computers. The station broadcasts 4 hours of news, social and entertainment programming between $6 \mathrm{pm}$ and $10 \mathrm{pm}$ every day to the residents of the capital city and its environs. ${ }^{380}$

In August 2014, the government took the first steps to digitize TV broadcasting in the country. ${ }^{381}$ The completion of this process, still behind schedule as of December 2017,

\footnotetext{
${ }^{378}$ Situation of female Afghan journalists in 8 provinces in 2017 in their own voices, Centre for the Protection of Afghan Women Journalists, 30 December 2017, http://www.cpawj.org/2017/12/31/- سال

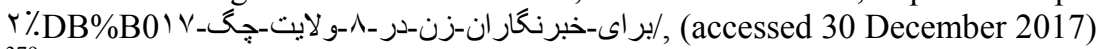

${ }^{379}$ Japan's contributions to Afghanistan: working on the frontline in the war on terrorism, Ministry of Foreign Affairs, Government of Japan, page 2, http://www.mofa.go.jp/region/middle_e/afghanistan/pamph0703.pdf, (accessed 20 September 2017)

${ }^{380}$ Bamyan national radio television, RTA Voice Magazine, second volume, page 34, Kabul, November 2016, http://www.rta.org.af/wp-content/uploads/2016/11/complet.pdf, (accessed 13 December 2017)

${ }^{381}$ Afghanistan official launches digital TV broadcasting, digitaltvnews.net, 1 September 2014, http://www.digitaltvnews.net/?p=24674, (accessed 13 December 2017)
} 
will level the playing field not only for local TV stations such as Bamyan TV but for all TV and radio stations around the country. A research participant in Kabul said the main reason for the slow rollout of the digitization process was "the incapability of ATRA," the national ICT regulator. However, the same research participant added, another noteworthy reason was that "some powerful TV stations are against it," fearing that they'll lose their dominant position in the sector. ${ }^{382}$

\subsection{Press, broadcasting and ICT penetration}

In terms of ICT infrastructure, the Afghanistan National Development Strategy put particularl emphasis on the role of ICT in the country's economic and social development. The main goal of the government's strategy for the information and communication sector is: "To make affordable communication services available in every district and village of Afghanistan through enabling market economy, so that all Afghans, men and women alike, can use ICT to expeditiously improve Government, social services, foster the rebuilding process, increase employment, create a vibrant private sector, reduce poverty and support underprivileged groups." 383 The strategy also specifically aimed to "promote transparency and citizen access to public information." 384 The strategy also established a national ICT Council, which includes one representative from the media

\footnotetext{
382 Author interview with research participant in Kabul, 7 May 2017

${ }^{383}$ Information and communication sector strategy, Afghanistan Telecommunications Regulatory Authority, pages 19, http://atra.gov.af/Content/files/ICT\%20Sector\%20Strategy-English.pdf, (accessed 20 July 2017)

${ }^{384}$ Information and communication sector strategy, Afghanistan Telecommunications Regulatory Authority, page 10, http://atra.gov.af/Content/files/ICT\%20Sector\%20Strategy-English.pdf, (accessed 20 July 2017)
} 
sector as a permanent member. ${ }^{385}$ Additionally, the strategy document was developed in consultation with Afghan government ministries, the United Nations, donor countries, NGOs, civil society and the private sector. ${ }^{386}$

As a result, over the past 15 years as a whole, the sector has grown exponentially. As shown in Table 8 below, the country went from zero mobile phone users in 2001 to more than 21 million mobile phone subscribers in 2016. Given the total population of some 30 million, the mobile phone subscriptions in 2016 show a ratio of 66 mobile phones per 100 inhabitants. ${ }^{387}$

Table $8:^{388}$ Growth of mobile phone subscriptions in Afghanistan (2002-2016)

\begin{tabular}{|l|l|l|}
\hline No. & Year & Number of mobile phone subscribers \\
\hline 1 & 2001 & 0 \\
\hline 2 & 2002 & 25,000 \\
\hline 3 & 2003 & 200,000 \\
\hline 4 & 2004 & 600,000 \\
\hline 5 & 2005 & $1,200,000$ \\
\hline 6 & 2006 & $2,520,366$ \\
\hline 7 & 2007 & $4,668,096$ \\
\hline
\end{tabular}

385 Information and communication sector strategy, Afghanistan Telecommunications Regulatory Authority, page 37, http://atra.gov.af/Content/files/ICT\%20Sector\%20Strategy-English.pdf, (accessed 20 July 2017)

${ }^{386}$ Information and communication sector strategy, Afghanistan Telecommunications Regulatory Authority, page viii, http://atra.gov.af/Content/files/ICT\%20Sector\%20Strategy-English.pdf, (accessed 20 July 2017)

${ }^{387}$ Estimate of the country's population in 2017, page 2, Central Statistics Office, Afghanistan, http://cso.gov.af/Content/files/تخمين/Final\%20Population\%201396.pdf, (accessed 15 December 2017)

${ }^{388}$ Country ICT data (until 2016), mobile-cellular subscriptions, Afghanistan, International Telecommunications Union, https:/www.itu.int/en/ITU-D/Statistics/Pages/stat/default.aspx, (accessed 14 December 2017) 


\begin{tabular}{|l|l|l|}
\hline 8 & 2008 & $7,898,909$ \\
\hline 9 & 2009 & $10,500,000$ \\
\hline 10 & 2010 & $10,215,840$ \\
\hline 11 & 2011 & $13,797,879$ \\
\hline 12 & 2012 & $15,340,115$ \\
\hline 13 & 2013 & $16,807,156$ \\
\hline 14 & 2014 & $18,407,168$ \\
\hline 15 & 2015 & $19,709,038$ \\
\hline 16 & 2016 & $21,602,982$ \\
\hline
\end{tabular}

Similarly, as detailed in Table 9, the percentage of the population using the internet increased from zero in 2003 to 10.6 percent by 2016 .

Table $9:{ }^{389}$ Growth of internet use in Afghanistan by percentage of population (20022016)

\begin{tabular}{|l|l|l|}
\hline No. & Year & Number of internet users (in millions) \\
\hline 1 & 2002 & 0 \\
\hline 2 & 2003 & 0.09 \\
\hline 3 & 2004 & 0.11 \\
\hline 4 & 2005 & 1.2 \\
\hline 5 & 2006 & 2.11 \\
\hline 6 & 2007 & 1.9 \\
\hline 7 & 2008 & 1.84 \\
\hline
\end{tabular}

\footnotetext{
${ }^{389}$ Country ICT data (until 2016), Percentage of individuals using the internet, Afghanistan, International Telecommunications Union, https://www.itu.int/en/ITU-D/Statistics/Pages/stat/default.aspx, (accessed 14 December 2017)
} 


\begin{tabular}{|l|l|l|}
\hline 8 & 2009 & 3.55 \\
\hline 9 & 2010 & 4.0 \\
\hline 10 & 2011 & 5 \\
\hline 11 & 2012 & 5.45 \\
\hline 12 & 2013 & 5.9 \\
\hline 13 & 2014 & 7 \\
\hline 14 & 2015 & 8.26 \\
\hline 15 & 2016 & 10.6 \\
\hline
\end{tabular}

Although still very low by global standards, according to the 2017 International Telecommunications Union report, Afghanistan's ICT Development Index ranked 159 globally. This showed a significant improvement of six points over the 2016 ranking of 165. ${ }^{390}$ Also, the ITU ranked Afghanistan as the country with the highest growth rate of ICT Opportunity Index in the period 2001-2005. ${ }^{391}$

According to a 2012 study of the ICT sector in Afghanistan, there are currently six telecom service providers and at least 44 licensed internet service providers (ISPs), which use a country-wide network of more than 4,400 telecom base stations as "the backbone for mobile services and wireless connectivity" ${ }^{392}$ The report states that "given the growth of both the legal and enabling environment and industry practice, Afghanistan has built a modern telecom sector that has increased access to information, economic opportunities,

\footnotetext{
${ }^{390}$ ICT Development Index, 2017 Ranking, International Telecommunication Union, http://www.itu.int/net4/ITU-D/idi/2017/index.html, (accessed 14 December 2017)

${ }^{391}$ World information society 2007 reprot, Internatioanl Telecommunication Union, page 131, http://www.itu.int/osg/spu/publications/worldinformationsociety/2007/WISR07_full-free.pdf, (accessed 14 December 2017)

392 Javid Hamdard, The state of telecommunications and internet in Afghanistan six years later (20062012), March 2012, pages 8 and 10 https://www.internews.org/sites/default/files/resources/Internews_TelecomInternet_Afghanistan_201204.pdf, (accessed 15 December 2017)
} 
and overall standard of living for ordinary citizens." ${ }^{, 393}$ The Afghan telecom sector has attracted nearly $\$ 2$ billion in private investment, which provides coverage to 85 percent of the population with a penetration rate of 64 percent in all of the country's 34 provinces. Costs have also come down dramatically: a sim card that cost $\$ 250$ in 2003 was available for less than a dollar in 2012 and domestic calling cost went from $\$ 0.36$ to $\$ 0.06$ in the same period, a drop of 500 percent. $^{394}$

A research participant said the investments in this sector had dramatically changed the situation in the country. "Penetration of press, broadcasting and ICT has been significant in Afghanistan. Despite pervasive security challenges and tough geography, the expansion of media and ICT can be considered a remarkable achievement of the past 15 years," he said. "Mobile companies and their attempts in providing cheaper cellular data, particularly for data bundles for Facebook, has played a major role in expanding ICT in the country."395

A research participant in Nangarhar said the main challenges preventing people in rural areas from accessing internet was high prices and lack of electricity, which are also reasons for the dominance of radio in rural communities. ${ }^{396}$

\footnotetext{
393 Javid Hamdard, The state of telecommunications and internet in Afghanistan six years later (20062012), March 2012, pages 46, https://www.internews.org/sites/default/files/resources/Internews_TelecomInternet_Afghanistan_201204.pdf, (accessed 15 December 2017)

394 Report: rapid growth of Afghanistan's ICT sector paves the way for new media and a stronger economy, Internews, 19 April 2012, https:/www.internews.org/updates/report-rapid-growth-afghanistans-ict-sectorpaves-way-new-media-and-stronger-economy, (accessed 16 December 2017)

395 Author interview with research participant in Kabul, 8 July 2017

${ }^{396}$ Author interview with research participant in Nangarhar, 8 May 2017
} 
Despite the phenomenal growth of ICT infrastructure and services over the past fifteen years, penetration rates, especially in terms of internet access, are low. This is a key area where the government must make necessary investments in partnership with the private sector that dominates the ICT market in Afghanistan. As one research participant noted, it is especially critical to extend ICT services to the village level where most Afghans still live. With better internet access, the research participant said, "if I'm a villager in Afghanistan and I want to grow strawberries, I can go online and google that and improve my farming and make a bigger profit. "It will also help students study better. It will also improve access to information which is a basic human right.” The research participant also contended that, as shown in the case of mainstream media outlets in the cities, reliable and affordable internet access will also help local media outlets. "Local media outlets who have good internet connections with low prices can broadcast through the internet and they can also do their research online and expand the quality and coverage of their programming," he said. "The local outlets can have their Facebook page, develop a website and do much more, such as provide news and information to Afghan diaspora communities around the world about news and developments in their home villages." This could create a platform for members of the diaspora communities to contribute to the development of their own communities "through contributions that are small for them but can have large impact in Afghan villages." 397

Internews Afghanistan contributed to the development of a Gender Policy for Community Radio in 2008, which underlined that the "role of media in promoting the

\footnotetext{
${ }^{397}$ Author interview with research participant in Kabul, 7 May 2017
} 
women's equality is vital." The policy noted, "Women need to have access to the airwaves, in terms of the ability to make their own programs about political and social issues and entertainment, and also to have programs that deal with women's issues."398 As noted in Chapter 5, of the 166 radio stations in the country, at least 16 are operated mostly by women. For example, in 2008, Radio Sahar, in the western province of Herat, had a total staff of 16 , out of which 11 were women, which is a very high ratio in the deeply conservative society. ${ }^{399}$ At the same time, many of these radio stations offer programming specific to women's issues and needs.

Other ways in which media outlets, especially community/local radio stations, provide news and information to the rural communities were discussed in detail in chapters 4 and 5.

As detailed in Chapter 4, civil society organizations in Afghanistan have played an important role in promoting press freedom and independent media over the year. Additionally, according to an assessment of civil society organizations in 2005, "the growth of an independent media sector, in particular, has been hailed as one of the country's biggest civil society successes, as well as a key element in its transition to a democratic system." The report noted that roughly a quarter of civil society organizations

\footnotetext{
${ }^{398}$ Gender policy for community radio, Women's International Network, 8 March 2008, pages 2-3, http://www.amarc.org/documents/Gender_Policy/GP4CR_English.pdf, (accessed 15 August 2017)

${ }^{399}$ Survey report: practices of community radios in natural disaster management situations, World Association of Community Radio Broadcasters, 5 October 2008, page 6, http://www.amarc.org/documents/rapports/Survey_Report_CR_Disaster_management.pdf, (accessed 15 August 2017)
} 
undertook activities relevant to promoting press freedom and media development in the country. ${ }^{400}$

\subsection{Conclusion}

The findings in this chapter showed that overall there is adequate infrastructure in the media sector in Afghanistan today, largely thanks to the flow of generous grant assistance from international sources.

This is true both in terms of the rebuilding of physical infrastructure for the media, particularly the state broadcaster RTA and its affiliates in the provinces, but also in terms of the provision of technical equipment to independent media outlets and journalists. The key challenge here of course is the vulnerability of the entire sector in terms of future growth, maintenance and renewal of existing infrastructural and technical resources in the event of a precipitous drop in levels of foreign assistance, especially when the domestic economy is not yet strong.

The growing reach and penetration of internet, so far limited largely to educated and urban segments of society, has also created another powerful platform for the dissemination of information. This platform is also widely used by traditional media outlets to amplify their programming and reach larger audiences. Further expansion of

\footnotetext{
4002013 Afghanistan civil society assessment, Langer Research Associates and Counterpart International for the United States Agency for International Development, January 2014, pages 29-30, http://www.langerresearch.com/wp-content/uploads/I-PACS_II_Report_Web_Final.pdf, (accessed 18 July 2017)
} 
the internet network along with a parallel drop in pricing will certainly make online media, including social media platforms, increasingly significant in the years to come, including for rural residents who have yet to join and enjoy internet connectivity on par with their urban peers. The government will also have to address the lack of regulation for social media as a matter of priority. 


\section{Chapter: FINAL CONCLUSIONS AND RECOMMENDATIONS}

The preceding thesis has been an attempt to test the emergence and development of the Afghan media sector in the post-Taliban period against a clear set of indicators in the form of the United Nations Media Development Indicators, which have been specifically developed for this purpose.

Overall, the research conducted for this thesis showed that the Afghan media sector has gone through an unprecedented, phenomenal phase of growth and development in the past 15 years.

For instance, unlike the frequent fluctuations in the constitutional and legal guarantees for press freedom over several decades, the thesis illustrated the robust nature of the constitutional guarantees for press freedom and freedom of expression, and the largely pro-media legal framework that has developed in the post-Taliban years. Given the near impossibility of amending those sections of the constitution that cover fundamental rights and freedoms, including press freedom and freedom of expression, it is comforting to know that at least when it comes to legal protections, the Afghan media sector faces no significant risks. Indeed, few countries in the region, certainly none of Afghanistan's neighbours, provide the sort of broad freedoms and rights in the media sector, including editorial independence, the right to protect sources, no government censorship, etc. 
In terms of the quantitative growth of media outlets, the thesis showed that the sector went from a handful of Taliban-controlled radio and print outlets (TV having been outlawed by the regime) into a literal explosion of hundreds of media outlets in the aftermath of their ouster from power in late 2001. Under the Taliban, Afghan citizens were forced to either consume regime-controlled propaganda or risk punishment by secretly listening to such foreign media outlets as the BBC and Voice of America. Today, they can choose from a menu of dozens of TV and radio stations throughout the country and - thanks to the power of the internet and satellite TV - across the globe. Indeed, as shown by the research, technological advances in mass media and telecommunications (TV, radio, internet and mobile phones) have been a critical enabler for the spread and reach of private media inside and outside Afghanistan since 2001, thus vastly enhancing and increasing the reach of private media outlets to the people and the people's access to these outlets.

Today, literally every Afghan citizen is legally allowed to establish and run a private, independent media outlet without any sort of prior approval or censorship of their content by government functionaries. The low licensing fees for establishing a media outlet (e.g. $\$ 29$ for a newspaper or magazine and $\$ 43$ for a radio station) also means the initial cost of establishing a media outlet is by no means not prohibitive.

At the same time, the diverse set of media outlets populating the media scene represent the diversity of both the Afghan society and the country's power elite. Today, media owners in the country range from members of Afghanistan diaspora community who 
have returned home after decades, veterans of the country's media sector, overnight millionaires who got rich on the back of foreign military contracting all the way to political parties, former jehadi factions and powerful individuals representing the full spectrum of moderate, religious and conservative ideological orientations. Today, every major language in the country has at least one, two or more print and broadcast outlets to its name.

Also, despite the fact that the significant presence of partisan media outlets on the media scene is a long-term challenge to the growth and development of truly independent media, their presence and the freedom of expression they enjoy acts as a safety valve and peaceful alternative to their more violent methods of settling differences in the country's recent past. At the same time, the influence of such partisan outlets is greatly reduced by the fact that the majority of the population are aware of the partisan ownership and orientation of these outlets. Today, as evidenced by their overwhelming popularity compared to partisan media outlets, millions of Afghan citizens mainly rely on private independent media outlets for information, news and entertainment.

It also emerged that the diversity of the Afghan media extends to and covers underprivileged or minority groups such as women, the disabled and, at least in the case of state-run media outlets, speakers of ethnic minority languages. Given the continuing prominent role of Afghan women in the media sector - not just as reporters but also producers, managers and owners - it would be fascinating to explore the key motivations and factors behind their persistence, especially in the face of ongoing safety and security 
challenges and a conservative cultural milieu that is still not fully comfortable with strong public roles for women.

In addition, a major defining feature of the post-Taliban media development is the fact that the media sector has created a diverse source of information and news, and the broadest ever platform for national dialogue and citizen engagement over the most pressing issues in the country, including war and peace, elections, government performance and service delivery, rule of law and justice. As demonstrated by the research, given the nascence of the country's post-2001 democratic dispensation, the media sector has played an essential role in educating people about elections and reflecting and scrutinizing the programs and views of election candidates.

At the moment, Afghanistan continues to face a full-scale war, is undertaking efforts to strengthen national unity, reach peace with the Taliban and other armed opposition groups, is seeking to further build and develop its state institutions and is trying to revitalize its international relations and deepen its integration into the emerging new regional economic order largely centred around the role of China and India. Given these sensitive, complex and difficult issues, the role of an independent, robust media sector will continue to be vital in the years to come.

The thesis also highlighted the critical role that civil society organizations, primarily indigenous media support organizations have played in strengthening protections and guarantees for press freedom. These organizations have done this both through lobbying 
for a free, open and supportive media legal framework, by defending and enhancing the rights and freedoms of Afghan journalists through constant lobbying and advocacy with the government, parliament and other relevant actors. The role of the media support organizations, and the overall civil society organizations, in sustaining the independence of the media sector and further improving conditions will continue to be significant in the years ahead. The role of independent media in this midst is particularly important given the very high levels of public trust and confidence they enjoy. Parallel to highlighting the gains of independent media development in the country, the research project also outlined the key challenges and threats that independent media outlets and the media sector as a whole face.

Based on the evidence gathered and observation of the current situation of the country, the ongoing war and violence in the country continue to pose the single greatest threat to the media sector. There was a broad consensus on this among the research participants interviewed for this project. A significant number of Afghan journalists have fallen victim to the actions of the key sides in Afghanistan's long war, especially over the past decade, including the Taliban, criminal networks and individuals, national and international security forces and government officials. The fact that, proportionally more journalists have lost their lives and sustained injuries than in all the neighbouring countries combined is a staggering and sobering reality. And it is not just physical violence that Afghan journalists are constantly vulnerable to. They also endure endemic intimidation, pressure and scare tactics by all the above-mentioned parties to the country's conflict. Among other negative implications, this has resulted in a certain level 
of self-censorship, which is clearly detrimental to the ideal of a free, independent media and democratic development. Persistent insecurity and a weak judicial system also perpetuates a climate of impunity on the part of perpetrators of all types of violence against journalists. It is a tribute to the courage, fearlessness and resilience of Afghan journalists that they persist in their dangerous but essential work.

Another key long-term challenge that will persist until Afghanistan develops a developing, mature real economy will be the lack of sources for adequate financial support for the media sector, especially so in the case of independent media outlets.

The financial squeeze, above all, will also mean that a period of consolidation in the media sector will occur sooner or later. A sad but perfect illustration of this change is the dire financial straits in which the country's largest independent newspaper by circulation, Hahst e Subh published out of Kabul, finds itself today. In a public note to its readers via Twitter in April 2018, the paper's editor-in-chief, Parwez Kawa, said that the paper needed urgent financial support in order to maintain its operation and preserve its independence. In the note, he said "Hasht e Subh is an independent newspaper. We are seeking to create a stable, democratic, free and prosperous society." It noted that the advertising market in the country is both small and politicized, independent outlets were sidelined in this sector. The newspaper's note ended with a direct appeal to its readers to donate money to it.

Many quickly responded to the paper's appeal and committed their moral and, in some cases, financial support. For example, a former Deputy Foreign Minister, reacting to the 
appeal on twitter, said "the new Afghanistan cannot be built without free media and Hasht e Subh has already played a pioneering role. We all owe a debt and the least we can do is to ensure (the newspaper's) sustainability."401 Shaharzad Akbar, a prominent women's rights and civic activist who in 2018 joined the government as a senior advisor to the country's president, echoed the sentiment. "Help Hasht e Subh if you can," she wrote. "Independent media have significantly contributed to the social and cultural change, growth of democratic values and an engaged citizenry in Afghanistan. Print media like Hasht e Subh are platforms for important discussions about the present and future of Afghanistan". ${ }^{402}$ Well-meaning as the reaction to Hasht e Subh's financial troubles is, it is not clear whether counting on individual donations in a country that ranks among the poorest of the poor is a viable long-term model for financial sustainment of independent media outlets such as Hasht e Subh.

What would change the situation and help media outlets such as Hasht e Subh to survive and thrive is the revival of the Afghan economy. And the situation there does not inspire a lot of hope, at least for the time being. Although the economy has recovered from its steep slump in the immediate wake of the departure of most foreign forces from the country in 2014 - going from 1.3 percent growth in 2014 to 2.6 percent in 2017 and projected to reach 3.1 percent in 2019 - there is a long way to go in this area. ${ }^{403}$ Only when Afghanistan revives its place in the region as a natural landbridge for physical

\footnotetext{
401 Jawed Ludin, The new Afghanistan cannot be built without free media, Twitter.com/jawedludin, 16 April 2018

${ }^{402}$ Shaharzad Akbar, Help Hasht e Subh if you can, Twitter.com/shaharzadakbar, 14 April 2018

${ }^{403}$ Economic outlook, the World Bank in Afghanistan, World Bank, http://www.worldbank.org/en/country/afghanistan/overview, (Accessed 25 March 2018)
} 
connectivity, transit trade and the flow of people, energy and goods will the economy grow sufficiently large to allow for a big enough advertising pie that could sustain most of today's struggling independent media outlets.

Until the country develops such a mature, robust economy, the scales will continue to be tilted in favour of the politically-connected partisan media outlets, many of which not only receive financial support from domestic political actors but also from neighbouring states with their disparate political, ideological, security, economic and cultural agendas.

An interim solution could be a decision by the major donor countries that have contributed generously to the development of the media sector to pool their resources into a trust fund to be independently governed in accordance with best international practices. The good thing is that there are already well-functioning trust fund models in two other sectors in the country. The Law and Order Trust Fund (LOTFA), managed with help from the United Nations, pools support to the sustainment and development of the Afghan army and police whereas the Afghanistan Reconstruction Trust Fund (ARTF) channels development assistance. Given the significance of media funding and its impact on editorial independence, exploring the current state and future prospects of financial support for the media sector would be a particularly relevant and timely area of further research.

Also, although professional standards have improved over the years through foreignfunded training and trial and error, given the relative youth of the post-Taliban independent Afghan media and the largely archaic journalism curriculae taught at Afghan 
universities, this remains a long-term challenge and goal, including in such crucial areas as investigative journalism, libel and defamation issues, and the development of specialised reporting especially in the fields of economy, health, sports, etc.

Another major challenge that will require focused attention and hard work to overcome is the absence of effective government mechanisms to ensure the implementation of the laws and regulations in the media sector. Without the full and fair implementation of the law, the further development and entrenchment of the values and practices of independent media will face continuous hurdles and ups and downs. The Ministry of Information and Culture in its current form simply lacks the capacity and maybe even the willingness to carry out this vital function. Addressing this yawning gap will be a true test of the Afghan government's commitment to press freedom and freedom of expression because if the commitment is there, nothing could stop the introduction and implementation of necessary reforms. The reforms must either fix up the departments within the Ministry of Information and Culture responsible for media or result in the setting up of an independent arms-length state institution where all functions related to the media sector - from implementation of the laws and regulations to licensing and awarding of frequency and spectrum - can be brought under one roof. This reform, whatever shape it takes in the end, must also aim to take the promotion and enhancement of access to information, diversity in content, investigative journalism, standards for professional conduct, training and educational curriculae and programs throughout the country as its top priorities. 
The above are all rich topics for further research as the post-2001 Afghan media sector continues its growth and evolution. 


\title{
Bibliography or References
}

\section{Books and Articles}

\author{
Ahang, Mohammad Kazim. \\ -- A history of media in Afghanistan, 1977, Kabul, Historical Society of Afghanistan, Ministry of \\ Information and Culture \\ -- Afghan Media in the First Decade of Independence, Afghanistan Journalists Union, Kabul, 1990
}

\section{Chadwick, Patricia and Amina Azimi}

Raising the voices of the disabled in Afghanistan, Internews, 25 March 2016,

Retrieved from: https://www.internews.org/story/amina-azimi-raising-voices-disabled-afghanistan

\section{Colin Soloway and Abubakar Siddigue,}

USAID's assistance to the media sector in Afghanistan, October 2005, PPC evaluation paper No. 3 , Bureau for policy and program coordination, USAID

Retrieved from: http://pdf.usaid.gov/pdf_docs/PNADC219.pdf

\section{Copeland, David A.}

The Idea of a Free Press, Northwestern University Press (2006)

\section{Cray, Peter}

An Explosion of News: The State of Media in Afghanistan, February 2012,

Retrieved from: https://www.internews.org/sites/default/files/CIMA-Afghanistan_\%2002-23-12.pdf

\section{Curran, James.}

-- Media and Democracy, Routledge, (2011), page 47

-- Rethinking the media as a public sphere in: Communication and Citizenship: Journalism and the Public Sphere, edited by Peter Dahlgren and Colin Sparks (1991), Routledge, New York (1991)

\section{Dupree, Louis}

Afghanistan and the Unpaved Road to Democracy, Journal of the Royal Central Asian Society, 56(3), October 1969

\section{Eran Fraenkel.}

Afghanistan Media Assessment: Opportunities and challenges for peacebuilding, United States Institute of Peace, Washington DC,

Retrieved from:

https://www.usip.org/sites/default/files/resources/PW68_Afghanistan_Media_Assessment1.pdf

\section{Fairbairn, Jean}

Community media sustainability guide: The business of changing lives, Internews, 2009

Retrieved from: http://www.amarc.org/documents/manuals/InternewsCommunityMediaGuide2009.pdf

\section{Gurevitch, Miachel and Blumler, Jay G.}

Political Communication Systems and Democratic Values, 1990, pages 24-35

Retrieved from: http://www.csub.edu/ mault/political\%20communication\%20sys.pdf

\section{Hamdard, Javid.}

The state of telecommunications and internet in Afghanistan six years later (2006-2012), March 2012, Retrieved from:

https://www.internews.org/sites/default/files/resources/Internews_TelecomInternet_Afghanistan_201204.pdf 


\section{Javier, Luque}

Pioneer Award aids fight for Afghan journalits' safety, International Press Institute, 21 June 2017, Retrieved from: https://ipi.media/pioneer-award-strengthens-fight-for-journalist-safety-in-afghanistan/

\section{Kovach, Bill and Rosenstiel, Tom.}

The Elements of Journalism (revised and updated third edition), Three Rivers Press, New York, (2014)

\section{Levinson, Nan.}

Outspoken: Free speech stories, University of California Press, Berkeley and Los Angeles, California, 2003

\section{Misdaq, Nabi.}

Afghanistan: Political Frailty and External Interference, Routledge, New York, 2006

\section{Paffenholz, Thania and Spurk, Christoph.}

Civil Society, Civic Engagement, and Peacebuilding, Conflict Prevention and Reconstruction, Social Development Department, World Bank, October 2006, Retrieved from: http://siteresources.worldbank.org/INTCPR/Resources/WP36_web.pdf

\section{Partaw Naderi.}

The condition of media in Afghanistan, Afghanistan Civil Society Foundation, Maiwand Printing Press, 2007, Kabul

\section{Procter, Ann.}

Afghanistan's Fourth Estate: Independent Media, 10 August 2015,

Retrieved from: https://www.usip.org/publications/2015/08/afghanistans-fourth-estate-independent-media

\section{Rashid, Ahmed.}

Taliban: Islam, Oil and the New Great Game in Central Asia, I.B. Tauris, 2002

\section{Rothman, Paul.}

The Politics of Media Development: The Importance of Engaging Government and Civil Society, Centre for International Media Assistance, September 2015,

Retrieved from: http://www.cima.ned.org/wp-content/uploads/2015/08/CIMA-The-Politics-of-MediaDevelopment.pdf

\section{Rubin, Barnett.}

The Fragmentation of Afghanistan: State Formation and Collapse in the International System, Second Edition, Yale University Press, 2002

\section{Rustami, Akbar.}

Where did Facebook take the elections, Hasht e Subh daily, Kabul, 14 July 2014, Retrieved from: http://8am.af/1393/04/23/facebook-election-afghanistan/

\section{Saikal, Amin.}

Modern Afghanistan: A History of Struggle and Survival, I.B. Taurus, London, 2004

\section{Sarajlic, Eldar.}

Media and Diversity in Post-Conflict Countries, The Anna Lindh Foundation, 2014 Report, Retrieved from: http://www.annalindhfoundation.org/report/media-and-diversity-post-conflict-countrieseldar-sarajlic,

\section{Schudson, Michael.}

-- The Power of News, Harvard University Press, Cambridge, Massachusetts, (1995)

-- Discovering the News: A Social History of American Newspapers, Basic Books, New York, (1978), 


\section{Schultz, Julianne.}

Reviving the Fourth Estate: Democracy, Accountability and the Media, Cambridge University Press, (1998)

\section{Sparks, Colin.}

Globalization, Development and the Mass Media, Sage Publications, 2007

\section{Spurk, Christoph.}

Media and Peace Building Concepts, Actors and Challenges, Swisspeace, November 2002,

Retrieved from: http://www.swisspeace.ch/fileadmin/user_upload/Media/Publications/WP1_2002.pdf

\section{Stroehlein, Andrew.}

An Overview of Media Development and Post-conflict Transition, 3 April 2009

Retrieved from: https:/www.crisisgroup.org/global/overview-media-development-and-post-conflicttransition- 0

\section{Thanassis Cambanis,}

Foreign aid sustains fragile Afghan media, thanassiscambanis.com, 25 February 2011, Retrieved from: http://thanassiscambanis.com/sipa/?p=150

\section{Wahlberg, Helle,}

What next for media in Afghanistan?, International Media Support, 18 February 2016, Retrieved from: https://www.mediasupport.org/next-media-afghanistan/

\section{Witchel, Elisabeth.}

Getting away with murder, Committee to Protect Journalists (CPJ), 27 October 2016, Retrieved from: https://cpj.org/reports/2016/10/impunity-index-getting-away-with-murder-killedjustice.php 


\title{
Web:
}

\author{
Afghanistan Journalists Centre \\ -- Afghanistan journalists federation is established, 20 January 2013, \\ Retrieved from: http://www.afjc.af/index.php/newsmedia/centeral/kabul/532-1391-11-02-05-03-15.html \\ -- Afghan journalists approve national code of ethics, 25 May 2016, \\ Retrieved from: http://afjc.af/english/index.php/af-media-news/central-provinces/kabul/597-afghan- \\ journalists-approve-national-code-of-ethics.html \\ -- Faisal Karimi, Media in Afghanistan: Achievements, challenges and responsibilities, 17 December \\ 2011, \\ Retrieved from: http://afjc.af/index.php/11/416-1390-09-26-04-48-25.html, (accessed 20 August 2017) \\ -- Gunmen storm TV station in Kabul, 7 November 2017, \\ Retrieved from: http://afjc.af/english/index.php/af-media-news/central-provinces/kabul/636-gunmen- \\ storm-tv-station-kabul.html \\ -- Joint committee on the security of journalists and media outlets begins work, 2 October 2016, \\ Retrieved from: http://afjc.af/index.php/newsmedia/centeral/kabul/908-2016-10-04-12-55-33.html
}

\section{Afghan Journalists Safety Committee (AJSC)}

-- Six months report: January-June 2016, 1 July 2016

Retrieved from: http://ajsc.af/wp-content/uploads/2016/07/JAN-

JUN2016SixMonthsReportENGLISH.pdf

-- Training

Retrieved from: http://ajsc.af/advocating-media-rights/

\section{Altai Consulting}

-- Afghan Media in 2010: A Synthesis Report,

Retrieved from: http://www.altaiconsulting.com/wp-content/uploads/2016/03/Afghan-Media-in-2010.pdf

-- Afghanistan Media in 2014: Understanding the Audience, February 2015,

Retrieved

from: http://www.altaiconsulting.com/wp-content/uploads/2016/05/Altai-Internews-Afghan-Media-in-

2014.pdf

-- Social media in Afghanistan: Users and engagement, October 2017,

Retrieved from: https://www.internews.org/sites/default/files/2017-

12/Internews_Afghanistan_SocialMediaAssessment_Altai_2017-12.PDF

\section{Arg Presidential Palace of the Islamic Republic of Afghanistan}

-- Decree of President Ghani regarding institutionalization of culture of support for freedom of expression and (freedom of) the press, Afghan Presidential Palace, 22 January 2017

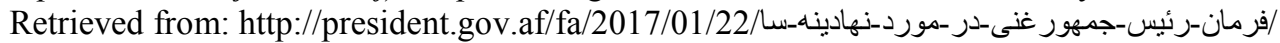

-- Hamid Karzai, Managers of media as the eyes and guides of society carry major responsibilities

towards the people and the country, 21 February 2013

Retrieved from: http://president.gov.af/fa/news/17655

- President Ghani calls freedom of express an important value of society, 16 May 2015,

Retrieved from: http://president.gov.af/fa/news/46280 (Author translation from Dari)

-- President Ghani's address to the U.S. Congress, 25 March 2015,

Retrieved from: http://president.gov.af/en/news/president-ghanis-address-to-the-us-congress,

-- President Ghani's remarks in the Council on Foreign Relations (CFR), Kabul, 26 March 2015,

Retrieved from: http://president.gov.af/en/speech/president-ghanis-remarks-in-the-council-on-foreignrelations-cfr/

-- President Ghani, through an order, waives previous outstanding tax dues of print and audio media, news agencies and publishing houses, 29 August 2017

Retrieved from: http://president.gov.af/fa/news/333231

\section{Asia Foundation}

-- A survey of the Afghan people 2015, November 2015,

Retrieved from: https://asiafoundation.org/resources/pdfs/Afghanistanin2015.pdf

-- A survey of the Afghan people 2017, 14 November 2017, 
Retrieved from: https://asiafoundation.org/wp-content/uploads/2017/11/2017_AfghanSurvey_report.pdf -- Afghanistan in 2014: A survey of the Afghan people

Retrieved from: http://asiafoundation.org/resources/pdfs/Afghanistanin2014final.pdf

\section{Atlantic Council}

A conversation with Afghanistan Presidential Candidate Dr. Ashraf Ghani, 20 May 2014,

Retrieved from: http://www.atlanticcouncil.org/news/transcripts/dr-ashraf-ghani

\section{Centre for the Protection of Afghan Women Journalists}

Situation of female Afghan journalists in 8 provinces in 2017 in their own voices, 30 December 2017,

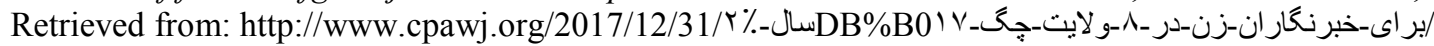

\section{Committee to Protect Journalists}

-- Thirty two journalists killed in Afghanistan, motive confirmed, Committee to Protect Journalists, Retrieved from: https://cpj.org/killed/asia/afghanistan/

-- Using new internet filters, Afghanistan blocks news site, 6 October 2010,

Retrieved from: https://cpj.org/blog/2010/10/using-new-internet-filters-afghanistan-blocks-news.php

\section{Freedom House}

-- Freedom of the Press Report on Afghanistan 2013

Retrieved from: https://freedomhouse.org/sites/default/files/FOTP\%202013\%20Full\%20Report.pdf

-- Freedom in the World 2015: Afghanistan

Retrieved from: https://freedomhouse.org/report/freedom-world/2015/afghanistan

-- Afghanistan profile, Freedom of the Press 2017,

Retrieved from: https://freedomhouse.org/report/freedom-press/2017/afghanistan

\section{Government Media and Information Centre (GMIC) of the Islamic Republic of Afghanistan}

-- About us

Retrieved from: http://www.gmic.gov.af/dari/gmic

-- Brief report on the activities of the national unity government in strengthening freedom of expression, 9 April 2017

Retrieved from: http://www.gmic.gov.af/dari/features/2964-2017-04-11-04-14-59

\section{Heinrich Böll Stiftung}

Demands of Afghanistan civil society on the occasion of Tokyo Conference on Afghanistan, 8 July 2012, Retrieved from:

https://www.boell.de/sites/default/files/assets/boell.de/images/download_de/worldwide/AfghanistanCivil SocietytoTokyo.pdf

\section{Herat University}

Introduction of Faculty of Journalism and Communication

Retrieved from: https://hu.edu.af/en/journalism

\section{Human Rights Watch}

Stop reporting or we'll kill you: Threats to media freedom in Afghanistan, 21 January 2015

Retrieved from: https://www.hrw.org/report/2015/01/21/stop-reporting-or-well-kill-your-family/threats-

media-freedom-afghanistan

\section{International Federation of Journalists}

Media for democracy in Afghanistan,

Retrieved from: http://www.ifj.org/uploads/media/110-Afghanistan-media_for_democracy.pdf 


\section{International Media Support}

Journalism in Afghanistan: Current and post-2014 threats and journalists safety mechanisms assessment, October 2013,

Retrieved from: https://www.mediasupport.org/wp-content/uploads/2013/12/afghanistan-safetyassessment-sept2013-ims.pdf

\section{International Telecommunications Union}

-- Country ICT data (until 2016), Percentage of individuals using the internet, Afghanistan, Retrieved from: https://www.itu.int/en/ITU-D/Statistics/Pages/stat/default.aspx

-- -ICT Development Index, 2017 Ranking

Retrieved from: http://www.itu.int/net4/ITU-D/idi/2017/index.html

-- World information society 2007 report,

Retrieved from: http://www.itu.int/osg/spu/publications/worldinformationsociety/2007/WISR07_fullfree.pdf

\section{Internet World Stats}

Afghanistan, Internet World Stats,

Retrieved from: http://www.internetworldstats.com/asia.htm

\section{Islamic Republic of Afghanistan}

-- Afghanistan National Development Strategy, Ministry of Foreign Affairs, Government of Afghanistan, Kabul,

Retrieved from: http://mfa.gov.af/Content/files/Volume\%204\%20ENG.pdf

-- Afghanistan National Peace and Development Framework (ANPDF) 2017 to 2021, Afghanistan

Permanent Mission to the United Nations,

Retrieved from: http://afghanistan-un.org/wp-content/uploads/2016/10/ANPDF.pdf

-- Bakhtar News Agency, Ministry of Information and Culture,

Retrieved from: http://moic.gov.af/fa/page/1290/2111

-- Culture, media and youth sector strategy, Ministry of Information and Culture, National Development Strategy of the Government of Afghanistan, Kabul,

Retrieved from: http://moic.gov.af/fa/page/1326

-- Conclusions of the Conference on Afghanistan and the International Community: From Transition to the Transformation Decade, Bonn Conference, Bonn, Germany, 5 December 2011, Ministry of Foreign

Affairs, Afghanistan,

Retrieved from:

http://mfa.gov.af/Content/files/Second\%20Bonn\%20Conference\%202011\%20Communique.pdf

-- Digitical television broadcasting inaugurated in Kabul, Ministry of Communications and Information

Technology, Kabul, 1 September 2014,

Retrieved from: http://mcit.gov.af/fa/news/mcit--opens-digital-tv-broadcasting

-- Estimate of the country's population in 2017, Central Statistics Office, Afghanistan,

Retrieved from: http://cso.gov.af/Content/files/تخمين/Final\%20Population\%201396.pdf

-- Independent Election Commission of Afghanistan

Retrieved from: http://www.votehere.af/\#/manual-map

-- Information and communication sector strategy, Afghanistan Telecommunications Regulatory

Authority,

Retrieved from: http://atra.gov.af/Content/files/ICT\%20Sector\%20Strategy-English.pdf

-- Joint committee for coordination on the security of journalists and media outlets chaired by second vice president, Independent Directorate of Local Governance, 25 January 2017,

Retrieved from: http://idlg.gov.af/fa/news/211030

-- Konkor results for all of Afghanistan by discipline in 1396 (2017), Kankor Exam, Afghanistan,

Retrieved from: https://konkor.ooyta.com/?pg=1395\&res=1\&lang=fa\&lang=fa

-- Speech of Sarwar Danesh, Second Vice President, at the 90th anniversary of the establishment of

Radio Afghanistan and the 40th anniversary of the establishment of Television Afghanistan, Office of the

Second Vice President, 21 September 2017,

Retrieved from: https://vpo.gov.af/18-بيانيه_استاد-سرور_دانش_معاون-دوم-رئيس/18 
-- Statement by his excellency Sarwar Danesh, Vice President of Islamic Republic of Afghanistan in the 71st session of the UN General Assembly, Office of the Second Vice President of Afghanistan, Kabul, 24 September 2016,

Retrieved from: https://vpo.gov.af/en/2016/09/24/statement-by-his-excellency-sarwar-danesh-vicepresident-of-islamic-republic-of-afghanistan-in-the-71th-session-of-the-un-general-assembly/ -- Universities and institutions of higher learning, Ministry of Higher Education, Afghanistan, Retrieved from: https://mohe.gov.af/prs/universities

\section{Kabul University}

-- About us, Afghanistan Centre at Kabul University

Retrieved from: http://acku.edu.af/about-us/

-- Current state and achievements of the Faculty of Journalism,

Retrieved from: http://ku.edu.af/fa/page/social-science/880/current-situation

-- Introduction, Siraj-ul-Akhbar Afghani, ${ }^{\text {st }}$ issue, page 1, 5 October 1911, Kabul

Accessed from the archives of the Afghanistan Centre at Kabul University

-- Short history of the Journalism Faculty at Kabul University,

Retrieved from: http://ku.edu.af/fa/page/social-science/880/history

\section{Kardan University}

Curriculum vitae of instructors, Journalism Department,

Retrieved from: http://www.kardan.edu.af/data/uploads/files/مختصر-سو انح-استادان.pdf

\section{Langer Research Associates for Counterpart International}

2013 Afghanistan civil society assessment, January 2014

Retrieved from: http://www.langerresearch.com/wp-content/uploads/I-PACS_II_Report_Web_Final.pdf

\section{Mediothek}

-- Media houses,

Retrieved from: http://mediothek-afghanistan.org/MediaHouses.html

-- Capacity building,

Retrieved from: http://mediothek-afghanistan.org/?q=en/CapacityBuilding.html

\section{Ministry of Communications and Information Technology of the Islamic Republic of Afghanistan}

-- Afghanistan Telecommunications Regulatory Authority fines telecom and internet companies, Kabul, 26 April 2011,

Retrieved from: http://mcit.gov.af/en/news/1175

-- ICT policy for Afghanistan: A digital agenda for development and social change (2015-2024),

Retrieved from: http://mcit.gov.af/Content/files/Draft-ICT\%20Policy\%20Document.pdf

-- Internet users,

Retrieved from: http://mcit.gov.af/Content/images/Eng\%20-\%20Internet\%20Users.png

-- Priorities of MCIT for the next three years,

Retrieved from: http://mcit.gov.af/en

-- Report of the activities and achievements of the Ministry of Communications and Information

Technology 2002-2015,

Retrieved from: http://mcit.gov.af/Content/files/book\%20of\%20coummnication.pdf

--Telecom Statistics end of September 2015,

Retrieved from: http://mcit.gov.af/en

-- Telecommunications and internet policy, Ministry of Communications, Islamic Transitional

Government of Afghanistan, November 2003,

Retrieved from:

http://mcit.gov.af/Content/files/AfghanistanTelecomPolicy_English29112010235311722.pdf

\section{Internews Network}

Internews Afghanistan: Risk management toolkit, code of ethics and a new radio station, 30 April 2009, Retrieved from: https://reliefweb.int/report/afghanistan/internews-afghanistan-risk-management-toolkitcode-ethics-and-new-radio-station 


\section{Ministry of Justice of the Islamic Republic of Afghanistan}

-- Constitution of the Islamic Republic of Afghanistan, Ministry of Justice, Kabul, 2004

-- Mass Media Law of the Transitional Government of Afghanistan, 2004,

Retrieved from: http://moj.gov.af/content/files/OfficialGazette/0801/OG_0824.pdf

-- Media Law of the Interim Administration of Afghanistan, 24 January 2002,

Retrieved from: http://moj.gov.af/content/files/OfficialGazette/0701/OG_0800.pdf

-- Mass Media Law of the Islamic Republic of Afghanistan, 2005,

Retrieved from: http://moj.gov.af/content/files/OfficialGazette/0801/OG_0871.pdf

-- Mass Media Law of the Islamic Republic of Afghanistan, 2009,

Retrieved from: http://moj.gov.af/content/files/OfficialGazette/0901/OG_0986.pdf

\section{Nai Media Institute}

-- Short courses,

Retrieved from: http://nmi.edu.af/short-courses

-- Diploma in Media,

Retrieved from: http://nmi.edu.af/diploma-media

\section{Nai supporting open media in Afghanistan}

-- Attack against Tolo TV workers a war crime that the people of Afghanistan will not forget, 24 January 2016,

Retrieved from: http://nai.org.af/dr/حمله-به-كارمندان-تلويزيون_طلوع-يك_جناى/, (accessed 18 August 2017)

-- Instances of journalists' murder, injuries, beaten, detain, insult and threat in 2016 in Afghanistan, Retrieved from:

http://nai.org.af/files/documents/mw/Media\%20Watch\%20annual\%20brief\%20report\%202016.pdf,

-- Media Watch Report: Monthly report number 141, February 2017

Retrieved from:

http://nai.org.af/files/documents/mw/Nai\%20Monthly\%20Report\%20English\%20141.pdf

-- Project overview

Retrieved from: http://data.nai.org.af,

-- The media community in Afghanistan is tired of the existence of the illegal commission for addressing media violations, 24 February 2013,

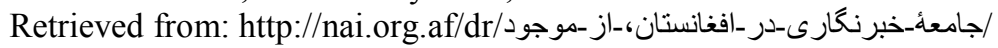

-- Twelve percent increase by women in Afghan media outlets, 20 March 2017,

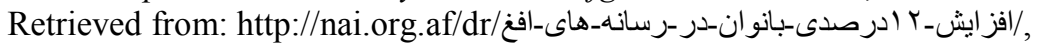

\section{Ministry of Foreign Affairs Japan}

Japan's contributions to Afghanistan: working on the frontline in the war on terrorism,

Retrieved from: http://www.mofa.go.jp/region/middle_e/afghanistan/pamph0703.pdf

\section{Organization for Economic Cooperation and Development (OECD)}

-- Monitoring the principles of good international engagement in fragile states and situations: country report 1: Islamic Republic of Afghanistan, 2010,

Retrieved from: http://www.oecd.org/countries/afghanistan/44654918.pdf

-- Review of the Afghanistan program: final version, May 2007,

Retrieved from: http://www.oecd.org/countries/afghanistan/39591223.pdf

\section{Reporters Without Borders}

Victims of the civil war,

Retrieved from: https://rsf.org/en/afghanistan

\section{Special Inspector General for Afghanistan Reconstruction}

USAID's Afghanistan media development and empowerment project: audit of costs incurred by Internews network, June 2015,

Retrieved from: https://www.sigar.mil/pdf/audits/Financial_Audits/SIGAR-15-64-FA.pdf 


\section{UNESCO}

-- Culture, Education and Media Projects in Afghanistan: what lessons can be learned, Retrieved from:

https://www.unesco.nl/sites/default/files/dossier/lessons_learned_afghanistan_1.pdf?download=1

-- Decision on Media Development Indicators adopted by the IPD C (International Program for the

Development of Communication) Intergovernmental Council at its 26th session, UNESCO Headquarters, Paris, 26 March 2008,

Retrieved from:

http://www.unesco.org/new/fileadmin/MULTIMEDIA/HQ/CI/CI/pdf/ipdc2008_decision_on indicators.p

$\underline{\mathrm{df}}$

-- Literacy rate among the population aged 15 years and older, United Nations Educational, Scientific and Cultural Organization Institute for Statistics

Retrieved from: http://uis.unesco.org/en/country/af

--Media Development Indicators: A Framework for Assessing Media Development, UNESCO, 2008

-- Statement on press freedom

Retrieved from: http://www.unesco.org/new/en/communication-and-information/freedom-of-

expression/press-freedom/)

-- Supporting Media Legislation,

Retrieved from: http://www.unesco.org/new/en/communication-and-information/freedom-of-

expression/dialogue-for-peace/media-in-conflict-and-post-conflict-situation-and-countries-in-transition//

\section{United Nations}

-- Afghanistan media training fosters freedom of expression, United Nations Assistance Mission for Afghanistan (UNAMA), 12 January 2011,

Retrieved from: https://unama.unmissions.org/afghan-media-training-fosters-freedom-expression

-- Joint committee drafts code of ethics for Afghan journalists, United Nations Assistance Mission to

Afghanistan, 23 April 2013,

Retrieved from: https://unama.unmissions.org/joint-committee-drafts-code-ethics-afghan-journalists

-- Security Council press statement on terrorist attack in Kabul, United Nations Security Council, 21

January 2017,

Retrieved from: https://www.un.org/press/en/2016/sc12215.doc.htm

-- Secretary General's Message to Asia Media Summit, Beijing, 25 May 2010,

Retrieved from: https://www.un.org/sg/en/content/sg/statement/2010-05-25/secretary-generals-messageasia-media-summit-beijing

\section{United States Agency for International Development,}

Factsheet, Anaar multimedia centres, December 2012,

Retrieved from: https://www.usaid.gov/sites/default/files/documents/1871/Fact\%20Sheet\%20AMCs-

AMDEP\%20-\%20Dec\%202012\%20-\%20FINAL.pdf

\section{Women's International Network}

Gender policy for community radio, 8 March 2008, Retrieved from:

http://www.amarc.org/documents/Gender_Policy/GP4CR_English.pdf

\section{World Association of Community Radio Broadcasters}

Survey report: practices of community radios in natural disaster management situations, 5 October 2008, Retrieved from:

http://www.amarc.org/documents/rapports/Survey_Report_CR_Disaster_management.pdf 


\section{NEWS online}

A few words apropos the world press (freedom) day, Hasht e Subh, 3 May 2016, Retrieved from: http://8am.af/1395/02/14/world-press-freedom-day/

About us, 1TV

Retrieved from: http://www.1tv.af/en/about-us

Abdullah threatens to withdraw from Afghan political process, Voice of America News, 1 September 2014, Retrieved from: https://www.voanews.com/a/abdullah-threatens-to-pull-out-of-afghan-politicalprocess/2434906.html

Afghanistan: Hezb-i-Islami armed group signs peace deal, Al Jazeera.com, 22 September 2016, Retrieved from: https://www.theguardian.com/world/2017/may/04/afghan-warlord-gulbuddin-hekmatyar-returnskabul-20-years-call-peace

Afghanistan official launches digital TV broadcasting, digitaltvnews.net, 1 September 2014, Retrieved from: http://www.digitaltvnews.net/?p=24674

Afghanistan's universities accelerate on the virtual Silk Road, Geant Project, 5 December 2013, Retrieved from: https://geant3plus.archive.geant.net/MediaCentreEvents/news/Pages/Virtual_Silk_Road.aspx

Amendment of the media law is against the constitution, Ava Press, 29 January 2015, Retrieved from: http://avapress.com/vdccpeqsi2bqxs8.ala2.html

Bamyan national radio television, RTA Voice Magazine, second volume, page 34, Kabul, November 2016, Retrieved from: http://www.rta.org.af/wp-content/uploads/2016/11/complet.pdf

Draft of code of journalism ethics is approved, Radio Azadi, 26 May 2016, Retrieved from: https://da.azadiradio.com/a/27756461.html

F. Makhdoom, Second women TV channel to go on air in Kabul, The Kabul Times, 23 July 2017, Retrieved from: http://thekabultimes.gov.af/index.php/opinions/social/14537-second-women-tv-channel-to-go-onair-in-kabul.html

Frud Bezhan, Taliban declares Afghan TV networks legitimate 'targets, ' Radio Free Europe/Radio Liberty, 12 October 2015,

Retrieved from: https://www.rferl.org/a/taliban-declare-afghan-tv-networks-legitimatetargets/27302358.html

Government media centre established in Kandahar, Radio Azadi, 14 October 2010, Retrieved from: https://da.azadiradio.com/a/2190074.html

Government media and information centre inaugurated in Balkh, 12 December 2013, Frasi.ru, Retrieved from: http://www.farsi.ru/doc/8073.html

Government media centre in Herat begins work, 18 December 2013, Shafaqna.com, Retrieved from: http://afghanistan.shafaqna.com/media/item/21570 آغاز -به_كار_مركز -رسانه_هاى_حكومت_در هر.html

Homaira Alokozai, Officials of National Radio Television and Bakhtar News Agency: We don't have professional independence, Azadi Radio, Kabul, 15 January 2017,

Retrieved from: https://da.azadiradio.com/amp/28234441.html

Ken Auletta, Afghanistan's first media mogul, The New Yorker, 5 July 2010, Retrieved from: https://www.newyorker.com/magazine/2010/07/05/the-networker-2 
Lina Rozbeh Haidari - VOA Ashna TV anchor on state of journalism and digital media in Afghanistan, 17 September 2013,

Retrieved from: http://www.bitlanders.com/blogs/lina-rozbeh-haidari-voa-ashna-tv-anchor-on-state-ofjournalism-and-digital-media-in-afghanistan/71483

Ministry of Information and Culture reacts strongly to Hekmatyar's statements, Ariana News, Kabul, 30 April 2017,

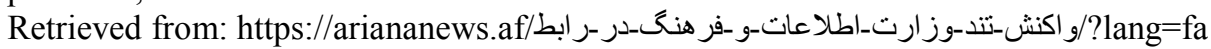

Report: rapid growth of Afghanistan's ICT sector paves the way for new media and a stronger economy, Internews, 19 April 2012,

Retrieved from: https://www.internews.org/updates/report-rapid-growth-afghanistans-ict-sector-pavesway-new-media-and-stronger-economy

Newstornado, English Newspaper

Retrieved from: http://www.newstornado.com/map/

The 2012 Pulitzer Prize winner: Massoud Hossaini, Time.com, 17 April 2012,

Retrieved from: http://time.com/42536/the-2012-pulitzer-prize-winner-massoud-hossaini/

Three killed, 21 injured in attack on TV station in Kabul, Ariana News, 7 November 2017,

Retrieved from: https://ariananews.af/three-killed-21-injured-in-attack-on-tv-station-in-kabul/

Zan: Afghanistan's First TV dedicated to the women of Afghanistan, The Daily Afghanistan, Kabul, 22 May 2017,

Retrieved from: http://www.dailyafghanistan.com/national_detail.php?post_id=140046

\section{Bakhtar News Agency}

-- Afghanistan Journalists Federation names 30 Jadee as black Wednesday in the history of Afghanistan's media, Kabul, 20 January 2017,

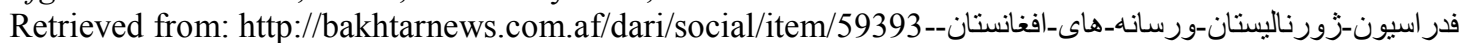

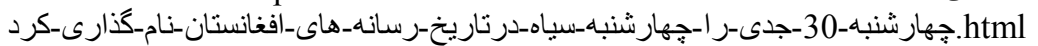

-- Bylaw for the operation of private mass media,

Retrieved from: http://bakhtarnews.com.af/dari/culture/item/1355--مقرره_فعاليت-رسانه_هاى_همخانى

خصوصى.html?tmpl=component\&print=1

\section{BBC}

-- Afghans plant flag in cyberspace, BBC News, 10 March 2003,

Retrieved from: http://news.bbc.co.uk/1/hi/technology/2835799.stm

-- Afghanistan profile - media, BBC News, 18 April 2017,

Retrieved from: http://www.bbc.com/news/world-south-asia-12013942

-- Afghanistan's national security council: Use Facebook responsibly, BBC Persian News, 6 June 2014, Retrieved from: http://www.bbc.com/persian/afghanistan/2014/07/140706_k04_facebook_in_afghanistan

-- Afghan television channel Shamshad TV back on air after attack, BBC News, 7 November 2017 , Retrieved from: http:/www.bbc.com/news/world-asia-41898011

-- Ethnic game and political disunity, BBC Persian News, Kabul, 27 October 2016, Retrieved from: http://www.bbc.com/persian/afghanistan-37786153

-- Ghani asks journalists to determine the limits of freedom of expression, BBC Persian, 4 May 2016, Retrieved from:

http://www.bbc.com/persian/afghanistan/2016/05/160504_k04_ghani_to_address_press_freedom_day_ce remony

-- Ramin Anwari, Director general of RTA resigns, BBC Persian, 24 July 2007,

Retrieved from: http://www.bbc.com/persian/afghanistan/story/2007/01/070124_ram-roshan-resign.shtml -- Seven journalists of Moby media group killed in Taliban attack, BBC Persian, Kabul, 20 January 2017, 
Retrieved from: http://www.bbc.com/persian/afghanistan/2016/01/160120_fm_kabul_sucide_attack

-- Taliban 'outlaw internet', BBC News, 13 July 2001,

Retrieved from: http://news.bbc.co.uk/1/hi/world/south_asia/1437852.stm

-- The media of Afghanistan: The challenges of transition, BBC Media Action, March 2012, page 9, Retrieved from:

http://downloads.bbc.co.uk/mediaaction/policybriefing/bbc_media_action_afghanistan_is_in_transition.p df

\section{Pajhwok Afghan News}

-- Kabul newspapers, http://www.elections.pajhwok.com/en/content/kabul-newspapers

-- Journalists guide about reflecting the demands and views of the people, 2014,

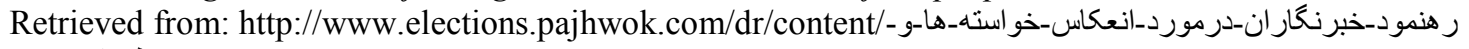
نظريات-مردم,

-- Mohammad Halim Karimi, Media as a principal force in democratic governments have great importance, 17 July 2017,

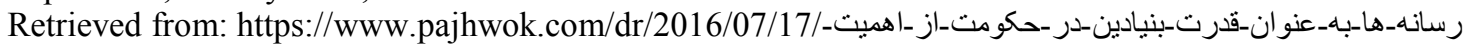

فراوان-برخورداراند,

-- The motivation for more women in journalism, 11 September 2017,

Retrieved from: https://www.pajhwok.com/en/2017/09/11/motivation-more-women-journalism

-- Report on lessons learned in the elections, Transparent Elections Foundation of Afghanistan, Kabul, 8

June 2014,

Retrieved from: http://www.elections.pajhwok.com/dr/node/15036

-- Zahra Nazari, Nai speaks about an increase in the number of women journalists in the media, 20 March 2017 ,

Retrieved from: https://www.pajhwok.com/dr/2017/03/20/از _افز ايش-تعداد_خبرنكار ان-زن_در-رسانه_ها_خبر _داد

\section{TOLO News / TV}

-- About us, Tolonews.com,

Retrieved from: http://www.tolonews.com/about-us

-- About us, Tolo.tv,

Retrieved from: http://www.tolo.tv

-- Afghanistan's press has been free in the past thirteen years, 2 May 2014,

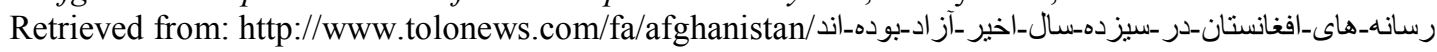

-- Amini, Karima, Officials: Taliban are turning civilian houses into fighting positions in the battle of

Kunduz, 12 May 2017,

Retrieved from: http://www.tolonews.com/fa/afghanistan/provincial/مقا_طالبان_در -جنگ_E2\%80\%

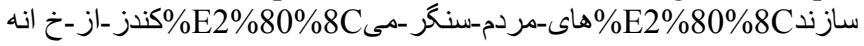

-- Anders Sjoberg, Celebrating the 250th anniversary of the passing of the first press freedom law,

Tolonews.com, 6 December 2017,

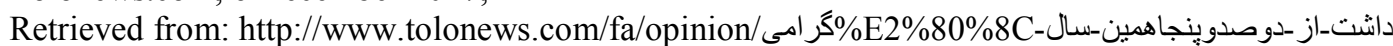

تصويب-ر(نخستين-قانون_آز ادى-مطبو عات

-- Anisa Shahid, Hekmatyar's second attack against the media after his appearance in public, Tolo

News, Kabul, 30 April 2017,

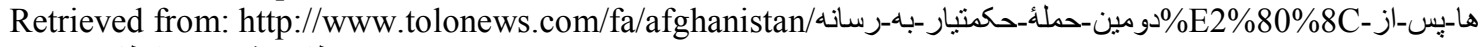

ظاهر -شدن-در -انظار -عمومى : ت

-- Black and White: Ex-president Karzai on his presidential journey, 3 September 2015

Retrieved from: https://www.youtube.com/watch?v=92pYA-EkUhE

-- Karzai: The principle of freedom of expression in Afghanistan is irreversible, 28 January 2014,

Retrieved from: http://www.tolonews.com/fa/afghanistan/كرزى-اصل_آز ادى-بيان-در _افغانستان-بركثت_نايذير -است

-- Gulabduddin Ghubar, People find media last option to raise their voices, Tolo News, 24 November

2017 ,

Retrieved from: http://www.tolonews.com/index.php/afghanistan/people-find-media-last-option-raisetheir-voices

-- Nabila Ashrafi, Nai reaction to Hekmatyar's statements about the media, Tolo News, Kabul, 1 May 2017 , 


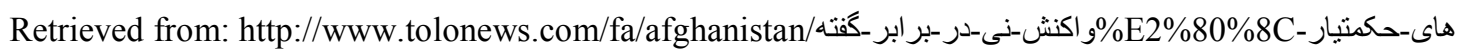
02\% هر -باره-رسانه

-- END -- 